
Digitized by the Internet Archive in 2007 with funding from Microsoft Corporation 


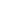




\section{.}


SCOTTISH POETRY OF THE EIGHTEENTH CENTURY. 
Pullished ly

Whithan Hodge \& Co., Glangow

Wuthams \& Nokgate, London and Edimburgh 


\title{
Abbotstoro series
}

of the

\section{$\cong \operatorname{cottigb}$ Roets}

Edited by GEORGE EYRE-TODD

\section{SCOTTISH POETRY OF THE EIGHTEENTH CENTURY}

\author{
VOLUNE I
}

LORD YESTER-LADY GRIZEL BAILLIE-LADY WARDLAWWILLHAY IIAMILTON OF MILBERTFIELD-SIR JOHN CLERK - AIIAN RAMSAY - ROBERT CRAWFORI ROBERT BLAIR-THE, ALTIIOR OF ALBANIA-ALEXANDER ROSS - JAMES THOMSON-DAVII) MALIET WILLIAY IIAILTON OF IBAGOUR - ALEXANDER WEBSTER-CIEORGE IIALKET-ALISON RUTIERFORDJOIN WILSON - SIR GILBEKT ELIIOT - TOMIAS SIOLLETT - ADAM SKIRVINGG-WILLIAM WILKIE TIIOMAS BLACKLOCK-JOIIN SKINNER-JOHN IIOMEJEAN ELLIOT-JOINN LAPRAIK-WILLIAM FALCONER-WILLIAM JULIUS MICKLE

LONDON AND EDINBURGH

SANISS \& COMPANI 
$\cdots+$ 


\section{Collego \\ Library}

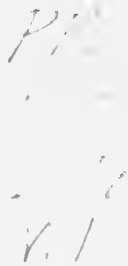

NOTE.

Is compiling these pages use has been made of a number of valuable, if partial, collections, such as Leyden's Scottish Descriptive Poems, Chambers's Songs of Scotland prior to Burns, Paterson's Ayrshire Contemporaries of Burns, Walker's Bards of Bon-Accord, and Harper's Bards of Galloway, to say nothing of the collections of the eighteenth century itself-Ramsay's Evergreen and Tea-Table Miscellany, Herd's Collection, and Johnson's Scots Musical Museum, Soc. Independent biographies, contemporary records, and original publications by the poets themselves have, however, in most cases been available.

In order to furnish, what has not existed hitherto, a comprehensive anthology of the eighteenth century poetry of Scotland, and to render the bead-roll of the poets as complete as possible, it has been found nccessary to extend the work to two volumes.

\section{9}

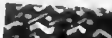





\section{CONTENTS.}

Scomtisil Poetry of the Eighteenth Century,

P'AGF.

LORI YESTER, •

Tweedside, . $\quad . \quad$. $\quad . \quad$. $\quad . \quad$. $\quad$. 9

LAIN GRIZEL BAILLIE, • . . . . . I I

"Werena my heart licht I wad dee,". . . 12

"The Ewe-buchtin's bonnie," . . . . . ' i4

LAMY WARDLAW, . . . . . . . . 15

Hardyknute, . . . . . . . . $\quad$ I7

Wiliman Hamiton of Gilbertfield, . . . 30

The Last Dying Words of Bonnie Heck, . . 3 I

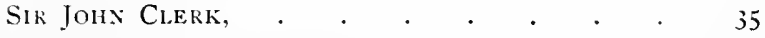

O Merry may the Maid be, . . . . 35

Allan Kansay, . . . . . . . 38

Elegy on Maggie Johnston, . . . . . . 4 I

Patie's Song, . . . . . . . . 46

leggy and Jenny (The Gentle Shepheri, Sc. II.), $\quad 4^{S}$

Epistle to William Hamilton of Gilbertfield, . 57 
AllaN RaMSAY-iontinued.

PALE

Lochaber no More, . . . . . . . 62

The Young Laird and Edinburgh Katie, . . 63

$\mathrm{Up}_{\mathrm{p}}$ in the Air, . $\quad . \quad . \quad . \quad . \quad . \quad . \quad . \quad 65$

The Widow,.$\quad$. $\quad . \quad$. $\quad . \quad . \quad .67$

ROBEKT CKAWFOK1), . . . . . . . . . 68

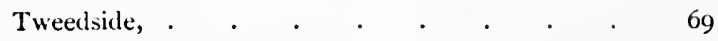

The Bush Abune Traquair, . . . . . 71

Doun the Burn, Davie, . . . . . . 73

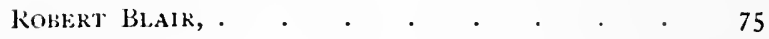

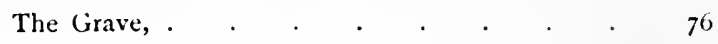

The Aulliok of Albania, . . . . . . $\mathrm{S}_{2}$

Allania, . . . . . . . . . 82

Alexanier loss, . . . . . . . . . . 87

Wooed and Married and A', . . . . . 88

Wvoed and Married and A', . . . . . 9 92

The Rock and the Wee l'ickle Tow, . . . 94

JAMES THOMSON, . . . . . . . . . . 98

Winter, . . . . . . . . 101

The Castle of Indolence, . . . . . . 113

DaVII MALLET, . . . . . . . IIU

William and Margaret, . . . . . $11 \mathrm{~S}$

kule Britannia, . . . . . . . . 121

The Birks of lnvermay, . . . . . . 123

Willad MaMhtox of baxiovk, . . . . 124

Song, . $\quad . \quad$. $\quad . \quad$. . . 120

The Braes of Yarrow, . . . . . . . 127 
ALEXANUEK WEISTEK, . . . . . . . 133

O, llow Could I Venture, . . . . . . 133

GHOKGE IIALKLT, . . . . . . . . . 135

Logic o' Buchan,. . . . . . . . . . 135

Alson RuTheklokn, . . . . . . . ${ }^{3} 37$

Lines to Mr. Walter Scot,. . . . . . 138

The Flowers of the Forest, . . . . . 140

JOHN WILSON, . . . . . . . . . 141

Clyde, . . . . . . . . . . 142

Sik GilheкT Ellat, . . . . . . I 48

Ny Sheep I Neglected, . . . . . 148

Tomas SHOLletr, . . . . . . . . . . 150

The Tears of Scotland, . . . . . . 152

Ude to Leven Water, . . . . . . . . 155

ADAM SKIRVING, . . . . . . . . . . 157

Johnnic Cope, . . . . . . . . . 155

WhLLAM WHLKle, . . . . . . 160

The Death of Hercules, . . . . . 160

THOMAS BLACKLOCK, . . . . . . 172

Un Euanthe's Absence, . . . . . . 173

Ilappy Marriage, . . . . . . . 175

JoHx SkiNikk, . . . . . . . . . . 176

Tullochgorum, . . . . . . . . 177

The Ewie wi' the Crookit Horn, . . ISI

JoIIx HOMF, . . . . . . . . . . . 185

Douglas, . . . . . . . . . . $\quad$ IS 
Jean Elliot, . . . . . . . . . . 204

The Flowers o' the Forest, . . . . 205

JOHN LAPRAIK, . . . . . . . . 207

When I upon thy Bosom lean, . . . . 208

WilliAM FALCONER, . . . . . . . 209

The Smiling Plains, . . . . . 210

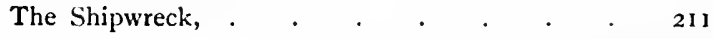

William Julius Mickile, • • • • . 224

The Sailor's Wife, . . . . . . . 226

Cumnor Hall, . $\quad$. . . . . $\quad 229$ 


\section{SCOTTISH POETRY OF THE EIGHTEENTH CENTURY.}

IT has been the fashion since the time of Scott and Byron and Wordsworth to look with something of disdain upon the English poetry of the days of Queen Anne and the early Georges. Nor is this disdain altogether without good reason. The poetic splendours of the Stuart period, the most glorious in the annals of English letters, appear to have flushed and paled in curious unison with the fortunes of the Stuart kings.* The exuberant blaze of imagination which followed the accession of James I., and spread to its widest in the

* Curiously enough, the great period of English genius is always termed Elizabethan, though the only great literary reputations which belong strictly to the reign of the Tudor queen are those of Spenser and Marlowe. Shakespeare, it is true, the greatest spirit of all, produced his earlier plays in Elizabeth s time; but "Hamlet" appeared in the year of James First's accession, and more than a dozen of the plays came afterwards. The works of Bacon, Jonson, Beaumont and Fletcher, Massinger, Ford, Webster, and Shirley-all the Shakespearean dramatists and poets, in fact-belong to the days of James I. and Charles I.; while the metaphysical and cavalier poets, with the great names of Milton and Butler and Bunyan, all came later, also within Stuart times. 
days of Charles, died down, strangely, as if extinguished, at the death of the latter monarch. Twelve years later, at the Stuart Restoration, the smouldering embers of national genius flashed again into fire- "Paradise Lost," "Hudibras," and the "Pilgrim's Progress" appeared, and there was a rekindling of Shakespearean drama in the works of IVycherley and Congreve, Otway and Lee. All this, however, was finally quenched at the Revolution in 1688 ; and the death of Dryden in the year I 700 severed the last link with a greater age.

Towards the close of the seventeenth century the standard of poetic merit in England had become one of intellect rather than of emotion. Head, as in all periods of poetic decadence, had taken the place of heart, and manner had come to be of more esteem than matter. For the glow of passion was substituted the brilliance of wit, and instead of the fire of creative imagination there remained only the play of a keenly critical but cold fancy. Poetry, further, fell into a classic mode which was entirely artificial and affected. The poet's mistress was no longer a simple English girl, but, like the court beauties of the time, masquerading in patches and powder and paste, must figure as a make-believe Chloris or Chloe or Phillis. In the verse of the period. Wordsworth has noted, 
there does not for several decades appear a single new simile drawn directly from nature; and some critics, like Professer Veitch, have been tempted to include the entire work of the "correct school," as it is called, in one sweeping condemnation of heartlessness and conventionalism. Whether such condemnation be wholly justified or not, one fact may be remarked. The poctic ideals of the early decades of the eighteenth century, the period in question, were wrought to their finest issue by the genius of Addison, Swift, and Pope, and the verse of these writers_- "The Campaign" and "Cato," "Baucis and Philemon" and "The Grand Question Debated," the "Essay on Criticism" and the "Essay on Man"-despite its brilliance of wit and rhetoric, and the high estecm in which it was held in its own day, is hardly now read except by students of literature.

It was to Scotland that the first inspiration of greater things was to be owed. There, an interesting succession of events had cleared the way for a new beginning. A hundred years earlier, in the end of the sixtecnth century, the stern Calvinism of Knox and the Reformers had succeeded in choking the copious ancient stream of national poesy. Lyndsay and Maitland. James V. and Alexander Scot and 
Alexander Montgomerie were without legitimate successors. Next, the removal of the court to London in 1603 had turned the genius of the north into an exotic vein, and for fifty years Scotsmen like Sir William Alexander, Drummond of Hawthornden, and the Marquis Montrose, wrote on an English model and in the English tongue. Then, amid the political troubles of the country, had come a pause-the air was too stormy for the bird of poesy to take wing.

It was late in the evening of the seventeenth century that, as in the first nights of spring, the sweet new singing began to be heard. Out of the simple old folk-songs and ballads of Scotland-the lilts that had been crooned over cradle and spinning wheel, and the rude lays of battle and love that had lingered for ages in the memory of the people-came the first inspiration of the new world of song. Francis Semple gave the sign, with his "Piper of Kilbarchan" and other picces, of a return to native and natural themes. But the more general note was struck later. Lord Yester and Lady Grizel Baillie were the real leaders of those who, singing of humble love and sorrow, went back to the old, simple wells of human nature for their subject. A few years after Lord Yester's time, James IVatson and Allan 
Ramsay gathered and published their collections of popular minstrelsy. Then Ramsay's own "Gentle Shepherd" appeared. This at once struck the keynote of the new natural and romantic movement in poetry. From that period, though Pope and the brilliant constellation of his followers continued, in shining rhetoric and sparkling wit, to write of "nymphs" and "cupids" and "the fair," to apostrophise the winds as "zephyrs" and the heart as "the vital urn," there was growing in Scotland a sincerer school-Thomson was painting winter as he actually knew it on Teviotside; Hamilton of Bangour and John Home were drawing story and inspiration alike direct from the old narrative ballads; and Jean Elliot and Isobel lagan were singing sweetly of Flodden Field and love among the hills.

It is true that Pope was not without a following among Scotsmen in the eighteenth century. The names of Smollett, and Falconer are enough to prove the fact. But the main current of Scottish poetry ran in the fresher, more natural channel. Ramsay, with his humour and warmth of colour, his burnside scenery and pictures of shepherd life among the Pentlands, was succeeded by Robert Fergusson with his "Farmer's Ingle" and "Tron Kirk Bell"; and all the world knows how from these 
two poets the mantle descended upon a greater than either, Robert Burns.

Two currents are to be traced in the new poetic morement which originated at the beginning of the eighteenth century: Both departed definitely from the artificial and formal manner of the "Augustan" poets, and each took its way through a real world of living sight and sound; but while one ran in a channel among the simple and familiar, though beautiful, objects of ordinary life, the other followed a wilder and more daring course. The latter, the romantic movement, is to be traced from its well-head in ancient national ballads like "Gil Morice" and "The Douglas Tragedy," through works like John Home's "Douglas" and the Ossianic translations of Macpherson, to its culmination in the superb productions of Scott. The other, the movement of the "natural school" of poetry, followed what has alway's been a characteristic of Scottish genius, the love of wild nature and the love of colour. Descending through the descriptive "Seasons" of Thomson and the rerse of a dozen song-writers, it found its most rivid expression in the glowing word-pictures and passionate lyrics of the Ayrshire bard, and left its mark unmistakably on English letters in the poetry of Wordsworth.

Perhaps the genesis of these two schools is to 
be traced back to a much earlier period than the beginning of the eighteenth century, but it is enough here to note that, while the "natural" school secms to have derived its inspiration chicfly from the ancient lyrical and reflective poetry of Scotland, the romantic movement appears to have been the lineal inheritor of the more restless and adventurous spirit of the makers of the ancient narrative ballads.

One point further cannot escape the notice of the reader of eightecnth century Scottish poctry. Whatever the verse of the period may have owed in the way of inspiration or suggestion to the ancient ballads of the country, the century was not itself one of ballad production. Save for a few avowed imitations of the ancient style, like "Sir James the Rose," "The Bracs of Yarrow," "IVilliam and Margaret," and "Hardyknute," and the somewhat doubtfully dated composition, "The Queen's Marie," there is no narrative ballad to be attributed to the time. Ballads had been the natural outcome of an age of rude action, and that age was past. With a more orderly state of society had come a feeling for the finer things of life, and that feeling found expression in the true vehicle of emotion-song. A few swect extant lyrics may doubtless be attributed to an carlier day, and more recent years have not been without their tender and 
noble productions; but the eighteenth century, with the wealth of heart's melody which it poured forth, seems likely to remain for all time the song-century of Scotland.

Altogether, alike for the variety and for the richness of its poetic flower, the period remains -in striking contrast with the same period in England - certainly the fullest of emotional charm of all the epochs of the nation's muse. 


\section{LORD YESTER.}

\section{646-1713.}

John Hay, tenth Lord Yester, third Earl and second Marquis of Tweeddale, was, in the times of William III. and gueen Anne, hest known as an active politician. He married the only daughter of the famous Duke of Lauderdale, and seems to have inherited, along with that nobleman's great wealth, no small part of his influence in the state. At the head of the party known as the Squadrone Volante, he took a large share in effecting the union of the kingdoms. Macky, who wrote in the beginning of the ISth century, mentions him as " a short brown man," very modest, but hot when piqued, a great promoter of the trade and welfare of his country. His single known composition, which is highly praised by Veitch as "the earliest remaining Tweeddale song," was printed first by Herd in $\mathbf{1 7 7 6 .}$ Its air, which, like several others, has been attributed to David Rizzio, is given by Chambers in his Songs of Scotland prior to furns. It was adopted by Gay for one of the lyrics in his opera of "Polly" in 1729. Neidpath Castle, near Peebles. which then belonged to the family, was probably the scene of the song.

\section{TIVEEDSIDE.}

WhEN Maggie and I were acquaint

I carried my noddle fu' hie;

Nae lintwhite on $a^{\prime}$ the green plain,

Nae gowdspink ${ }^{I}$ sae happy as me.

But I saw her sae fair, and I lo'ed,

I wooed, but I cam' nae great speed:

so now I maun wander abroad,

And lay my banes far frae the Tweed. 
To Maggie my love I did tell, Saut tears did my passion express;

Alas! for I lo'ed her o'erweel, And the women lo'e sic a man less.

Her heart it was frozen and cauld,

Her pride had my ruin decreed;

Therefore I will wander abroad,

And lay my banes far frae the Tweed. 


\section{LAIOY GRIZEL, BAILLIE.}

I $665-1746$.

One of the most romantic and leest known incidents of the times of persecution in sicotland is that of the hiding and escapte of Sir l'atrick llume of Marchmont. Hume had leen concerned in the intrigues against the succession of the Catholic Duke of lork, and on that prince's ascent to the throne ats lames VII., lay in peril of his life. Strict search was marle for him, lut without success. His first place of concealment was the family vault in I'olwarth Kirk. Ilere, night after night, lraving kirkyard bogles and other terrors, his claughter Grizel lorought him such provisions as she was able to abstract without the notice of the servants. Amid the darkness of the charnelhouse, he beguiled the hours ly repeating to himself (ieorge Buchanan's Latin version of the P'salms. Afterwards he lay in a pit which Grizel with her uwn hands dug for him under a bed on the ground-floor of their house; and at last he escaped abroad. During their exile (irizel appears to have leen the mainstay of the imporerished household-cooking, cleaning, mendirg, and going to mill and market. This, too, while she hat anxieties enough of her own; for her lover, (Beorge Baillie of ferviswoud, to whom she was deeply attached, lay also under ban of the Government. After the Kevolution, however, she had het reward. The exiles then returned home, her father, after hokl. ing some of the highest offices of state under King William, was created Earl of Marchmont, and in 1692 she herself was married to the man of her heart.

Ier laughter, Lady Murray of Stanhope, has told the story of her life in a memoir published in I \$22. It is repeated also with historical details, in Tytler's Worthies. Lady Murray possessed a MS. volume in which Grizel, during the exile in Holland, had been accustomed to set down the songs she composed. Only two of these pieces, however, are now known to exist. "Werena my heart licht" was printed first in Kamsay's Tez-Tuble . Mi cellany and the Orplzew Caledonizs. It has been praised as one of the most pathetic laallads in the language, and its eighth and ninth stanzas acquire a further interest from the fact that Burn- 
applied them to his own forlorn condition in his last sad days at Dumfries. "The Ewe-buchtin's bonnie" was first printed on a lroadsheet by $C$. K. Sharpe, with an air composed for it by his father at the age of seven. To this fragment eight additional stanzas were adcled l,y. Thomas Pringle in the beginning of the present century, and the whole together forms the well-known song. Both pieces with their airs are printed in Chambers' Songs of Siotiand prior to burns.

\section{"WERENA MY HEART LICHT I IIAD DEE."}

There was ance a may, and she lo'ed na men;

I built. See biggit ' her bonnie bouir doun i' yon glen; But now she cries Dule and a well-a-day!

2 path. Come doun the green gate ${ }^{2}$ and come here away.

When bonnie young Johmnie cam' ower the sea He said he saw maething sae bonnie as me: 3 promised. He hecht 3 me baith rings and monie braw things: And werena my heart licht I wad dee.

4 sister. He had a wee tittiet that lo'ed na me, Because I was twice as bonnie as she: She raised sic a pother twixt him and his mother, That werena my heart licht I wad dee.

The clay it was set ancl the bridal to be5 sudden illness. The wife took a dwam ${ }^{5}$ and lay doun to dee; She maned, and she graned, out o' dolour and pain, rill he rowed that he ne'er wat see me again. 
His kin was for ane o' a higher degree, Said, what had he to do wi' the like o' me? Albeit I was bonnie, I wasna for Johnnic: And werena my heart licht I wad dee.

They said I had neither cow nor calf, Nor dribbles o' drink rins through the draff, Nor pickles o' meal rins through the mill-e'e; And werena $m y$ heart licht I wad dee.

His tittie she was baith wily and slee, She spied me as I cam' ower the lea, And then she ran in and made a loud din; Believe your ain een an ye trow na me.

His bannet stood aye fu' round on his browHis auld ane looked aye as weel as some's new; But now he lets 't wear ony gate ${ }^{\mathrm{I}}$ it will hing, ${ }^{1}$ way. And casts himsel dowie upon the corn-bing.

And now he gaes drooping about the dykes And a' he dow do is to hund the tykes ${ }^{2}$ : The live-lang nicht he ne'er steeks ${ }^{3}$ his e'e: And werena my heart licht I wad dee.

Were I young for thee as I haie been We should ha'e been gallopin' doun on yon green, And linkin' it + on the lily-white lea: 4 going arm-inAnd wow gin I were but young for thee: 


\section{"THE EIVE-BUCHTINS BONNIE."}

a ewefolding. 'THE ewe-buchtin's' bonnie, baith e'enin' and morn, When our blithe shepherds play on the log-reed and horn;

While we're milking, they're lilting, baith pleasant and clear;

But my heart's like to break when I think on my dear.

O the shepherds take pleasure to blow on the horn, To raise up their flocks o' sheep soon i' the morn; On the bonnic green banks they feed pleasant and free,

But alas, my dear heart, all my sighing's for thee: 


\title{
LADY IVARDLAW.
}

\author{
$1677-1727$.
}

The earliest and in some respects most curiou. of the literary mysteries for which the eighteenth century remains notorious was that concerning the authorship of the lua!lad of llarlyknute. This composition, then, as now, a fragment, was published by James Watson at Edinburgh in 1719 in a neat folio edition of twelve pages. An apparently earlier, but undated and less tinished, copy is known to have been in the possession of the well-known editor, David I aing. liegarding the piece Lady Wardlaw of Pitreavie told a romantic story. She had discovered it, she said, written on some shreds of paper used for the bottoms of weaving clues. The statement was accepted in good faith, the Inllad was hailed as a genuine antique poen by men of taste like Lord I'resident Forleses and Elliot of Yinto, the Lord Justice-Clerk, and was included by Allan lamsay in his Evirgrien in $\mathbf{1 7 2 4}$, among the "poems wrote by the ingenious before 1600 ." In doing this, Ramsay took the liberty of altering the orthography to restore it, as he supposed, to something like its original antique shape.

So the matter stood till 1767 . Is a contemporary account of an episode of the battle of Largs fought in 1263, "Ilardy" knute "was looked upon as the oldest extant historical ballad in the Scots tongue, taking precedence in this respect of "Sir Patrick Spens." But in 1767 Lord IIailes communicated a new piece of information for the second edition of Percy's Reliques. Certain critics, it appeared, had doubted the antiquity of the work. In consequence Lady Wardlaw had been questioned, had admitted the authorship, and, to put the matter beyond loubt, had added two fresh concluding stanzas.

The question, nevertheless, did not rest here. In his Siottish Tragic Rallads in $178 \mathrm{I}$, Pinkerton printed an amendel version of the ballad, including a second part which completed the story. For this version and the conclusion he avowed indebtednes, to "the memory of a Lady in Lanarkshire." Later, in his Silect Scottish Ballats ( $\mathrm{I}_{3} \mathrm{~S}_{3}$ ) and in his Ancient Scottish Poems (17S6), this unscrupulous editor admitted the added second part to be his own composition, but regarding the original poem he made a new statement upon the authority of an alleged communi. cation of Lord Hales. The new story was that Sir John Bruce of kinross, in a letter to Lord Binning, had narrated his tinding of the WS. in an old vault in I lunfermline, and, desiring to 
screen his own connection with the fragment, had induced Lady Wardlaw to become its foster-parent. Pinkerton's new statement was accepted, apparently without question, by Bishop Percy, and, accordingly, in the fourth edition of the Reliques, "Hardyknute" is attributed directly to Sir John Bruce. These conflicting statements appear to have left some doubt in the mind even of the historian of Scottish poetry, Dr. Irving.

It was not till the year $I S_{30}$ that the question was finally cleared up. Among Pinkerton's correspondence, then published, appeared a letter from Lord Hailes, dated December 2, 1785 , explicitly disavowing the new statement to which his name had been attached, and reasserting the authorship of Lady Wardlaw.

Lord Hailes was of opinion that the ballad had been founded on some antique fragment, and he quoted a statement of Thomson, the editor of the Orpheus Caledonius of 1733 , that he had heard parts of it repeated in his infancy, before Lady Wardlaw's copy was heard of. But against these considerations there exists the explicit statement of Lady Wardlaw's daughter that her mother was the author of the ballad, and from the internal evidence of the composition itself it is impossible now to believe that any part of it is ancient.

Whatever may be thought of the method of its introduction to the public, there can be little doubt of the considerable merit of the ballad itself, though it must always appear somewhat affected and faint in colour beside folk-songs of more spontaneous origin. Gray and Warton both praised it very highly, and Irving terms it the most poetical production of its period. Sir Walter Scott in his Minstrelsy called it "a most spirited and beautiful imitation of the ancient ballad," and on the flyleaf of his copy of Ramsay's Ei'ergreen was found written " "Hardy. knute" was the first poem I ever learned, the last that I shall forget."

Lady Wardlaw, whose Christian name was Elizabeth, was the second daughter of Sir Charles Halket of Pitferran, and was married in 1696 to Sir Henry Wardlaw of Pitreavie, in Fife. Though Sir Charles IIalket averred that she wrote other poems, no further composition from her pen is known to be extant. Robert Chambers, however, at one time took great critical pains to show that some twenty-five of the finest scots ballads. including "Sir Patrick Spens," were of her authorship. In this idea, curiously enough, he has been recently supported by Professor Masson (in Edinizurgh Skitihes and Memories). But Chambers in a later volume abandoned the theory, and its arguments have been treated as insufficient by the editors of all ballad collections.

In the present pages "Hardyknute" is restored for the first time to the style of the edition of 1719 , of which a copy is preserved in the Adrocates Library, with the addition, of courne, of the two tinal stanzas from the Ea'ergreen. The stanzas in brackets are not included in the Adrocates' Library edition. 


\section{HARDYKNUTE.}

A FRAGMENT.

Stately stept he east the wa', And stately stept he west;

Full seventy years he now had seen

With scarce seven years of rest.

He lived when Britons' breach of faith

Wrought Scotland mickle wae, And ay his sword tauld to their cost

He was their deadly fae.

High on a hill his castle stood,

With ha's and towers a height, And goodly chambers, fair to see,

Where he lodged mony a knight.

His dame, sae peerless anes and fair,

For chast and beauty deemed, Nae marrow had in all the land Save Elenor the queen.

Full thirteen sons to him she bare, All men of valour stout;

In bloody fight, with sword in hand, Nine lost their lives but ${ }^{\mathrm{I}}$ doubt. ${ }^{1}$ without. 
Four yet remain, lang may they live To stand by liege and land;

High was their fame, high was their might, And high was their command.

Great love they bare to Fairly fair, Their sister saft and dear;

I slender.

Her girdle shaw'd her middle jimp ${ }^{1}$, And gowden glist her hair.

What waefou wae her beauty bred!

Waefou to young and auld, Waefou, I trow, to kyth and kin, As story ever tauld.

The King of Norse in summertyde, Puffed up with power and might, Landed in fair Scotland the isle With mony a hardy knight.

The tidings to our good Scots King Came as he sat at dine With noble chiefs in brave Aray, Drinking the blood-red wine.

"To horse, to horse, my royal liege, Your faes stand on the strand, Full twenty thousand glittering spears The King of Norse commands."

"Bring me my steed Magre, dapple-gray!" Our good King rose and cried;

"A trustier beast in all the land

A Scots King never tried. 
"Go, little page, tell Hardyknute,

That lives on hill so hie,

To draw his sword, the dread of faes,

And haste and follow me."

The little page flew swift as dart

Flung by his master's arm,

"Come down, come down, Lord Hardyknute

And rid your king of harm."

Then red, red grew his dark-brown cheeks,

Sae did his dark-brown brow;

His looks grew keen as they were wont

In dangers great to do.

He's ta'en a horn as green as glass,

And gi'en five sounds sae shrill

That trees in greenwood shook thereat,

Sae loud rang every hill.

His sons in manly sport and glee

Had passed that summer's morn,

When lo, down in a grassy dale,

They heard their father's horn.

"That horn," quo' they, "ne'er sounds in peace;

We've other sport to bide ${ }^{\mathrm{r}}$."

And soon they hied them up the hill,

And soon were at his side.

"Late, late yestreen I weened in peace

To end my lengthened life;

My age might well excuse my arm

Frae manly feats of strife; 
But now that Norse does proudly boast

Fair Scotland to enthrall,

It's ne'er be said of Hardyknute

He feared to fight or fall.

"Robin of Rothesay, bend thy bow,

Thy arrows shoot sae leal;

Mony a comely countenance

They've turned to deadly palt.

Braid Thomas, take ye but your lance-

You need nae weapons mair;

If you fight wi't as you did anes

'Gainst Westmoreland's fierce heir.

"Malcolm, light of foot as stag

That runs in forest wild,

Get me my thousands three of men

well bred to sword and shield.

1 armour.

Bring me my horse and harnisine ${ }^{x}$,

My blade of metal clear."

If faes but kenn'd the hand it bare

They soon had fled for fear.

"Fareweel, my dame sae peerless good:"

And took her by the hand;

"Fairer to me in age you seem

Than maids for beauty famed.

My youngest son shall here remain,

To guard these stately towers,

And shut the silver bolt that keeps

Sae fast your painted bowers." 
And first she wet her comely cheeks

And then her bodice green,

Her silken chords of twirtle twist,

Well plet ${ }^{1}$ with silver sheen ${ }^{2}$;

And apron set with mony a dice ${ }^{3}$

Of needlewark sae rare,

s plaited.

2 fair, shining.

3 i.e. die, square.

(1)odern word.)

Wove by nae hand, as ye may guess,

Save that of Fairly fair.

And he has ridden o er muir and moss,

O'er hills and mony a glen,

When he came to a wounded knight

Making a heavy mane.

"Here maun+ I lie, here maun I die

4 must.

By treachery's false guiles:

Witless I was that ere ga'e faith

To wicked Woman's smiles!"

"Sir Knight, gin you were in my power,

To lean on silken seat,

My lady's kindly care you'd prove,

Who ne'er kenn'd deadly hate.

Herself would watch you a' the day,

Her mails a' dead of night,

And Fairly fair your heart would cheer,

As she stands in your sight.

["Arise, young knight, and mount your steed,

Full lowers the shining day;

Choose frae my menzies whom ye please

5 following.

To lead ye on the way." 
With smileless look and visage wan

The wounded knight replied,

"Kind chieftain, your intent pursue,

For here I maun abide.

"To me nae after day nor night

Can ere be sweet or fair:

But soon beneath some drooping tree

Cauld death shall end my care."

With him nae pleading might prevail:

Brave Hardyknute, to gain,

With fairest words and reason strang

Strave courteously in vain.]

xhence.

Syne he has gane far hynd' out o'er

Lord Chattan's land sae wide.

That lord a worthy wight was aye

When faes his courage 'sayed

Of Pictish race by mother's side,

When Picts ruled Caledon-

Lord Chattan claimed the princely maid When he saved Pictish crown.

[Now with his fierce and stalwart train

He reached a rising height

Where, braid encampit on the dale,

Norse army lay in sight.

2 comrades.

"Yonder, my valiant sons and feres".

Our raging reivers wait,

On the unconquered Scottish sward

To try with us their fate. 
"Mak' orisons to him that saved

Our souls upon the rood,

Syne bravely show your veins are filled

Then.

With Caledonian blood.

Then forth he drew his trusty glaive,

While thousands all around,

Drawn frae their sheath, glanced in the sun,

And loud the bugles sound.

To join his king, adown the hill

In haste his march he made,

While, playing pibrochs, minstrels meet

Afore him stately strade.

"Thrice welcome, valiant stoup" of war,

'Thy nation's shield and pride:

Thy king nae reason has to fear

When thou art by his side."]

When bows were bent and darts were thrawn,

For thrang scarce could they flee;

The darts clove arrows as they met,

The arrows dart 3 the tree.

2 support.

Lang did they rage and fight fou fierce

With little skaith to man,

But bloody bloody was the field

Ere that lang day was done.

The king of Scots, that sinle brooked 4

The war that looked like play,

Drew his braid sword and brake his bow,

Sin' bows seemed but delay. 
Quoth noble Rothesay, "Mine I'll keep:

I wat it's bled a score."

"Haste up, my merry men," cried the king, As he rode on before.

The King of Norse he sought to find,

I begin the fight in mannerly fashion.
With him to mense the faucht ${ }^{x}$;

But on his forehead there did light

A sharp and fatal shaft;

As he his hand put up to find

The wound, an arrow keen,

$O$ waefou chance! there pinned his hand In midst, between his een.

“Revenge, revenge!" cried Rothesay's heir, "Your mail-coat shall na bide

The strength and sharpness of my dart."

Then sent it through his side.

Another arrow well he marked,

It pierced his neck in twa;

His hands then quat the silver reins,

He low as earth did fa'.

"Sair bleeds my liege: sair, sair he bleeds!"

Again with might he drewAnd gesture dread-his sturdy bow;

Fast the braid arrow flew.

3 aimed at.

Lament now Queen Elgreed:

High dames too wail your darling's fall, His youth and comely meed. 
"Take aff, take aff his costly jupe"!"

$t$ crat.

Of gold well was it twined $^{2}$,

Knit like the fowler's net through which

His steely hamess shined.

"Take, Norse, that gift frae me, and bid

Him venge the blood it bears;

Say, if he face my bended bow

He sure nae weapon fears."

Proud Norse, with giant body tall, Braid shoulders, and arms strong,

Cried, "Where is Hardyknute sae famed

And feared at Britain's throne?

The Britons tremble at his name;

I soon shall make him wail

That e'er my sword was made sae sharp,

Sae saft his coat of mail."

'That brag his stout heart couldna bide,

It lent him youthful might;

"I'm Hardyknute this day," he cried,

"To Scotland's king I heght 3

'To lay thee low as horse's hoof;

Iy word I mean to keep."

Syne with the first stroke e'er he strake

He garr'd his body bleed.

Norse een like grey grosshawk's stared wild;

He sighed with shame and spite-

"Disgraced is now my far-famed arm,

That left you power to strike :" 
Then ga' his head a blow sae fell,

It made him down to stoop

As low as he to ladies used

In courtly guise to lout.

Fou soon he raised his bent body,

His bow he marvelled sair,

Sin blows till then on him but darr'd ${ }^{x}$

As touch of Fairly fair.

Norse marvelled too as sair as he

To see his stately look-

Sae soon as e'er he strake a fae

Sae soon his life he took.

[Where, like a fire to heather set,

Bold Thomas did advance,

A sturdy fae, with look enraged,

$\mathrm{U}_{\mathrm{p}}$ towards him did prance.

He spurred his steed through thickest ranks

The hardy youth to quell,

Who stood unmoved at his approach,

His fury to repell.

"That short brown shaft sae meanly trimmed,

Looks like poor Scotland's gear,

But dreadful seems the rusty point."

And loud he leugh in jeer.

"Aft Britons' blood has dimmed its shine;

This point cut short their vaunt."

Syne pierced the boisterous bearded cheek-

Nae time he took to taunt. 
Short while he in his saddle swung,

His stirrup was nae stay,

Sae feeble hung his unbent knee-

Sure token he was fey'.

1 doomed.

Swith ${ }^{2}$ on the hardened clay he fell,

2 Quickly.

Right far was heard the thud;

But Thomas looked not as he lay

All weltering in his blood.

With careless gesture, mind unmoved,

On rode he north the plain,

He seemed in thrang of fiercest strife

When winner aye the same.

Nor yet his heart dame's dimpled cheek

Could meise ${ }^{3}$ saft love to brook,

Till rengeful Ann returned his scorn;

Then languid grew his look.

In throes of death, with wallowit 4 cheek,

+ faded.

All panting on the plain,

The fainting corpse of warriors lay,

Ne'er to arise again-

Ne'er to return to mative land,

Nae mair with blithesome sounds

To boast the glories of the day,

And show their shining wounds.

On Norway's coast the widowed dame

May wash the rocks with tears-

May lang look oer the shipless seas

Before her mate appears. 
Cease, Emma, cease to hope in vain ;

Thy lord lies in the clay:

The valiant Scots nae reivers thole ${ }^{\mathrm{x}}$

To carry life away.]

There, on a lea where stands a cross

Set up for monument,

'Thousands fou fierce that summer's day

Killed keen war's black intent.

Let Scots, while Scots, praise Hardyknute,

Let Norse the name aye dreadAye how he fought, aft how he spared,

Shall latest ages read.

Loud and chill blew the westlin wind, Sair beat the heary shower, Mirk a grew the night ere Hardyknute

Wan near his stately tower.

His tower that used wi' torches' blaze

To shine sae far at night,

Seemed now as black as mourning weedNae marvel sair he sight 3.

["There's nae light in my lady"s bower,

There's nae light in my hall,

Nae blink shines round my Fairly fair,

Nor ward stands on my wall.

What hodes it? Robert, Thomas say:"

Nae answer fits their dread,

"Stand back, my sons, I'll be your guicle;"

But by they passed with speed, 
"As fast I've sped ower Scotland's faes-" There ceased his brag of war, Sair shamed to mind aught but his dame, And maiden Fairly fair.

Black fear he felt, but what to fear He wist not yet with dread; Sair shook his body, sair his limbs, And all the warrior fled.? 


\section{WILLIAM HA.IILTON OF GILBERTFIELD.}

$$
1670-1751 \text {. }
$$

In a letter to Dr. Moore, Kobert Burns once wrote, "The story of Wallace poured a tide of Scottish prejudice into my veins which will boil along there till the floodgates of life shut in eternal rest." The "story of Wallace" thus alluded to, was of course Henry the Minstrel's great poem, but the version of that poem to which Burns, in common with most of his contemporaries, owed his acquaintance with the Minstrel, was a paraphrase into modern Scottish by Hamilton of Gilbertfield. This paraphrase has received scant praise at the hands of the critics, and in the matter of literary style it probably does not deserve much. Something, nevertheless, must be acknowledged as owing to the author whose translation made the work of the elder poet-what it otherwise could not have been-a living popular infuence in scotland for something like a century and $a$ half.

His paraphrase of the "Wallace" was not, however, Gilbertfield's best work. To Watson's Choice Colleition of Comic and Serions Scots Pocms, pullished in 1706, he contributed the set of verses on which his fame as a poet must be held to depend. "The last Dying Words of Bonnie Heck" was classed by Allan Kamsay with Semple's famous "Piper of Kilbarchan;" and Allan Cunningham has recorded his opinion that it is "a pretty little pathetic piece of poetry as ever was written." Its influence is to be traced, moreover, in at least one of the bestkrown compositions of Robert Burns.

William Hamilton-invariahly mentioned with his territorial title of "Gilbertfield," to distinguish him from the other William Hamilton of his time, the author of "The Braes of Yarrow-held in his youth a lieutenant's commission in the army, but while still young he gave 1 p his profession, and spent the rest of his days as a country gentleman. From his estate near Cambuslang, in the neighbourhood of Glasgow, he carried on a poetical correspondence with Allan Kamsay, which is generally printed in the works of that poet, ancl which afforded the model for the subsequent pretic epistles of Burns. (iillertfield being sold ultimately to the neighbouring laird of Westburn, Hamilton removed to Latrick, the other seat of his family in the same vicinity, and there he died on the $24^{\text {th }}$ of May, 1751 . 


\section{THE LAST DYING WORDS OF BONNIE HECK.}

A FAHOUS (iREYHOUND IN THE SHIRE OF FIFE.

"Alas, alas," quo' bonnie Heck,

"On former days when I reflect!

I was a $\operatorname{dog}$ much in respect

For doughty deed;

But now I must hing by the neck

Without remeed.

"O fy, sirs, for black, burning shame,

Ye'll bring a blunder on your name!

Pray tell me wherein I'm to blame?

Is't in effect

Because I'm cripple, auld, and lame?"

Quo' bonnie Heck.

"What great feats I have done mysel"

Within clink of Kilrenny bell,

When I was souple, young, and fell ${ }^{\text {, }}$,

But fear or dread,

John Ness and Paterson can tell,

Whose hearts may bleed. 
"They'll witness that I was the vier

Of all the dogs within the shire;

I'd run all day and never tire;

But now my neck,

It must be stretchèd for my hire!"

Quo' bonnie Heck.

"How nimbly could I turn the hare,

Then serve myself; that was right fair !

For still it was my constant care

The van to lead.

8 cunning wise.

Now what could sery ${ }^{1}$ Heck do mair?

Syne kill her dead.

"At the Kings-muir and Kelly-law,

Where good stout hares gang fast awa',

So cleverly I did it claw,

With pith and speed;

I bure the bell before them a'

As clear's a bead.

2 hares.

3 hindquarters.
"I ran alike on a' kind grounds,

Yea, in the midst of Ardry whins

I gript the maukins ${ }^{2}$ by the buns ${ }^{3}$

Or by the neck;

Where naething could slay them but guns, Save bonnie Heck. 
"I wily, witty was, and gash",

1 agacious.

With my auld felny packy pash²;

Nae man might ance buy me for cash

2 cruel, familiar head.

In some respect;

Are they not then confounded rash,

'That hang poor Heck?

"I was a bardy tyke3, and bauld; i forward dog.

'Though my beard's grey I'm not so auld.

Can any man to me unfauld

What is the feidt

+ feud.

To stane me ere I be well cauld?

A cruel deed!

"Now honesty was aye my drift,

An innocent and harmless shift,

A kail-pot lid gently to lift

Or aumrie sneck ${ }^{5}$ :

5 cupboard latch.

Shame fa' the chafts ${ }^{6}$ dare call that thift!" 6 cheeks, lips. Quo' bonnie Heck.

"So well's I could play hocus-pocus

And of the servants mak' Jodocus

And this I did in every locus,

Through their neglect;

And was not this a merry jocus?"

Quo' bonnie Heck. 
"But now, good sirs, this day is lost The best $\operatorname{dog}$ in the East-Neuk coast; For never ane durst brag nor boast Me, for their neck. But now I must yield up the ghost," Quo' bonnie Heck,

"And put a period to my talking, For I'm unto my exit making: Sirs, ye may a' gae to the hawking. And there reflect le'll ne'er get sic a dos for maukin

As bonnie Heck.

I quick at hunter's cry.

2 To carry them. selves.
"But if my puppies ance were ready Which I gat on a bonnie lady. They'll be baith clever, keen, and bedily. And ne'er neglect 'To clink it ${ }^{2}$ like their ancient daddy; The famous Heck." 


\section{SIR JOHN CIERK.}

\section{$1680-1755$.}

One of the Commissioners of the Union, and a Baron of the Scots Exchequer, the second baronet of I'ennicuik was one of the chief figures in the cultured society of Edinburgh cluring the first half of the eighteenth century. At his country-seat he entertained Allan Ramsay regularly every summer, and the deaths of his eldest son and of himself were anong the most lamented events of that poet's life. A close friend of the English antiquary, Roger Gale, he was himself an ardent collector of antiques, and a member of several of the learned societies. Clerk's chief works are treatises of law, economics, and antiquities; but the composition by which his name is popularly remembered is a song. "O merry may the maid be," of which the first verse is earlier than Clerk's time, was printed first in the Charmer of $\mathbf{I} 75 \mathrm{I}$, and later, with a final fifth stanza from the author's hand, in Ilerd's Collection of Ancient and Molern Scots Songs. Another poetical composition, of which Clerk is but the reputed author, was addressed to Susanna, daughter of Sir Archibald Kennedy of Culzean, and afterwards Countess of Eglinion. It was to this lady that Allan Ramsay dedicated his "(intle shepherd." Clerk, it appears, was enamoured of Miss Kennedy, and sent her a flute. Wher she tried to blow this it would not sound, and unscrewing it, she discovered the lines inside. They are in the ordinary fashion of love verses of the time, and may be found printed in Anderson's Scottish Nation.

\section{O MERRY MAY THE MAID BE.}

O MERRY may the maid be

'That marries wi' the miller, For, foul day and fair day, He's aye bringing till her. 
He's aye a penny in his purse For dinner or for supper, And, gin she please, a guid fat cheese, And lumps o' yellow butter.

When Jamie first did woo me

I asked.

I speer'd " what was his calling;

"Fair maid," says he, " $O$ come and see, Ye're welcome to my dwalling."

Though I was shy, yet I could spy

The truth o' what he told me,

2 pleasant. And that his house was warm and couth ${ }^{2}$, And room in it to hold me.

Behind the door a bag o' meal,

3 chest. And in the kist 3 was plenty $\mathrm{O}^{\prime}$ guid hard cakes his mither bakes, And bannocks werena scanty.

A guid fat sow, a sleeky cow Was standing in the byre, Whilst lazy puss with mealy mouse Was playing at the fire.

Guid signs are these, my mither says, And bids me tak' the miller;

For, foul day and fair day,

He's aye bringing till her.

For meal and maut she doesna want,

Nor onything that's dainty;

And now and then a keckling hen,

To lay her eggs in plenty. 
In winter, when the wind and rain

Blaws o'er the house and byre,

He sits beside a clean hearth-stane,

Before a rousing fire.

With nut-brown ale he tells his tale, Which rows him o'er fu' nappy. Wha'd be a King - a petty thing, When a miller lives so happy? 


\section{ALLAN RAMSAY.}

\section{686-1 758 .}

No Scottish poet, probably, has been subjected at once to praise so much beyond his merits and to detraction so grossly unjust to his cleserts, as Allan Rainsay. While by some it has been averred that he was merely a time-serving manufacturer of verse, who wrote what would sell, by others he has been extolled as not only the first but as one of the greatest of the singers of a new era. Burns himself spoke of Ramsay's " (ientle Shepherd" as the "most glorious poem ever written." Neither the eulogy nor the disparagement perhaps has been exactly just; but if indeed, as has been said of him, he appears to some to have been less a poet born than one made by eircumstances, it must also at least be said that by what he did for the muse of his country he merits a place in Scottish poetic history little behind that of the greatest makars, Barbour, Henryson, Dunbar, Lyndsay, and Burns.

Fourth in direct descent from a laird of Cockpen who was brother to Ramsay of Dalhousie, the poet was born at Leadhills, in the uplands of Lanarkshire on October 15,1686 . I His father was manager of Lord Hopetoun's lead mines on Crawford Muir, and his mother, Alice Bower, was the daughter of an Englishman who had been brought thither from I erbyshire to introduce improved methods of mining. While kamsay was still an infant his father died, and his mother married again. In the house of his stepfather, a small laird of the neiglbourhood, of the name of Crichton, the poet grew up till the age of fifteen, about which time he lost his mother. Apparently the lest was done for him that his stepfather could do when he was apprenticed to what was then the thriving trade of wig-making in Edinburgh. At this business Ramsay must have thrived, for in 1712 he married the daughter of an Edinburgh writer, Christian Ross by name, by whon he became the father of a numerous family. About the same time he became a member of one of the literary and political coteries which were then the vogue in Elinburgh. To the members of this society-a set of young gallants of suspected Jacobite leanings - the poet composed a humorous address, and they in turn clubbed him a gentleman and a good fellow. The Easy Club, as it was called, was suppressed, with other Jacolite societies, after the outbreak of the kebellion in 1715 .

kamsay's connection with this clul secured him a more or less sympathetic audience for his poetical compositions, and to 
that conneetion he owed his acquaintance with the valuable lust then unknown repository of ancient Seottish poctry, the Bannatyne MS. of 1568 . From this in 1716 he printerb James V.'s humorous poem "Christ's kirk on the Green," with an added canto of his own: and the publication was so well received that in 1718 he was encouraged to add a third part. By 1722 this work reached a tifth edition. Neanwhile Kamsay's fame had been growing. I'ieces like his "Elegy" on the Death of Maggic Johnston" and "Elegy on Luchy Wuod" were hawked on broadsheets; and it became a fashion with the burgesses" wives 10 send out for "Allan's last piece" un discuss over their dish of tea. In 1721 he collected these pieces and published them hy subscription, netting some four hundred gruineas by the transaction, and obtaining recognition at once as a distinguished poet. Three years later, in 1724 , he published the collections which, perhaps as much as his own original petry, were the means of recalling the muse of the country to native and natural themes.

"The Tea-Table Miscellany," of which the first volume was published then, and the third in 1727 , remains one of the best collections of songs which have ever been issued; while the "Evergreen," containing many poems from the Bannatyne MS., was the immediate means of clirecting popular attention to the rich but neglected stores of ancient Scottish poctry.

The latter publication was stated to consist of poems "wrote ly the ingenious before 1600;" but among other modern contents it included Lady Wardlaw"s "Hardyknute," and a poem "The Vision," stated to have been "compylit in Latin anno I 300," and signed "Ar. Scot.," which is agreed to be Ramsay"s wwn composition. In the following year, I725, the poet published his tinest and greatest work, "The Gentle shepberd." It had previously, on the moxlel of Henryson" "Robene and Malyne," written a couple of pastoral dialogues, one of which, "I'atie and kuger," was included in the volume of $\mathbf{I 7 2 I}$; and it is said to have leen suggested to him by friends that the public woutd be likely to welcome a complete pastoral on the model of these, -ubstituting real peasants and real scenery for the conventional thepherts and shepherdesses, nymphs and swains, and their artiticial surroundings, of the fashionable "pastorals" of his time. This suggestion Ramsay carried out, and the success of "The (ientle Shepherd" justified his attempt.

The pastoral drama thus written was the first of the greater vices of the new natural poetry which was to superiecle the work of the artificial school then in vogue. Its immediate -mecessor and imitator was "The Fortunate shepherdess" of Alesander Ross: hut even more vitally is its influence to le felt in the poetry of Fergusson, Burns, and Wordsworth.

It is to be regretted that the poet did not confine himsetf to :his natural vein, in which he proved himself so exquisite a craftiman. But the rogue of I'ope and his school exerted a 
strong influence upon him. So early as I 7 I 8 , when the "Iliad" of the Twickenham poet appeared, Ramsay had written to the translator a eulogistic epigram, and in imitation, and perhaps in emulation, of his English contemporary, he composed several elaborate pieces, like his "Morning Interview," "Health" a satirical poem, and a series of "Elegiacs." In r 728 were published his later poems, and in 1730 appeared his last look of verse, a collection of thirty fables, part original and part translated.

The poet was now forty-five years of age, and he devoted the rest of his days to business and the enjoyment of the position which fame had brought him. Till 1726 he had carried on his business of wig-making in a shop at the sign of the Flying Mercury, on the north side of High street, opposite Niddry's Wynd. Gradually, however, he had added bookselling to his occupation, and in the year mentioned he threw up wig-making, removed to a second-floor shop overlooking the market cross, and at the sign of the heads of Ben Jonson and Drummond of Hawthornden, established, with a full-Hedged bookselling business, the first circulating library in Scotland. Itere, close hy the Law Courts, his shop became the literary lounge of Edinburgh, and, numbering among his real friends many of the foremost Scotsmen of the day, Ramsay throve and was happy.

The single worldly misfortune which hefell the poet occurrel in 1737. Up to that time there was no theatre in Edinlurgl. Ramsay at his own sole expense built one in Carrubber's Close, and it was about to be opened when the Licensing Act placed a new power in the hands of the magistrates. A majority of the "city fathers," inheritors of the narrow and illiberal spirit of some of the early reformers, refused the license, and the poet was all but ruined. Thenceforth he kept to his proper business, and presently, recovering from his loss, he luilt limself a house which still stands, though now merged in the Students' Hostel, on the face of the Castle Hill. Two years earlier, in 1743, to his great grief, his wife had died, but the last thirteen years of his life he spent in his new romantic abode, glarklened by the growing fame of his son Allan, the portrait-painter to George III., and the society of his two tine daughters: and a great favourite with the young people who continually frepuented his house. He retired from lusiness in 1755 , and on Iamuary 7 , $175^{8}$, he died. He was buried quietly in Greyfriar Churchyarl.

Perhaps as good an irlea as any, of the personal appearance of the poet, is to be got from his statue by Sir John steel which stands close by the monument to Scott in Princes Street (iarlens; but references to his short, active tigure, his round humorul: face, dark twinkling eyes, and month ever ready with a merry epigram, live in alf the ledinburgh reminiscences of his time. Of all the great personages, indeed, who at that diay came and went on the plainstones of Edinlsurgh, none iv remembered more pleasantly and affectionately than the genial lowliseller-joet. 
Kamsay's collected works were pullished during his lifetime at London in $\mathbf{1 7 3 1}$, and at I)ublin in 1733. Later editions were produced at London in 1760, Glasgow in 1770, and Londen again in 1800 ; but probably the most ample was that edited hy the late Charles Mackay, and published by Virtue \& Co., London. A complete edition of his poems was also published by Gardner, I'aisley, in 1877 .

Like most other poets, from Chancer and Shakespeare to Burns and Tenuyson, Ramsay owed the suggestion of much of his work to poetic predecessors. Ifis humorous tale of "The Monk and the Miller's Wife" is merely a modernising of "The Freirs of Berwick," which has sometimes been attri. buted to Dunlar. Ifis "Vision" again is distinctly a reproduction of the sentiment and something of the machinery of Sir Davidl Lyndsay's "Dreme." His addlitions to "Christ's Kirk on the (ireen" stand avowed as to their initiative. Hlis elegies follow the verse and spirit of Semple's "Piper of Kilbarchan." And his "Morning Interview" borrows closely" both the manner and substance of Pope's "Rape of the Lock." Even his "Gentle Shepherd," as has heen seen, owed its lirst suggestion to IIenryson's pastoral, with which Ramsay was acquainted in the Bannatyne MS. Notwithstanding this fact, the real merit of Ramsay remains al,ove all question. IIis humour, and his sympathy with the humours of actual life, were all his own. Ilis songs, especially the humorous one:, remain, though not now much sung, typical of the gayer Scottish muse. Ilis poetical correspondence with men like Hamilton of Gilbertfield revived and added new lustre to a traditional exercise of the makars. And to say nothing of the influence of his "Evergreen" in reawakening interest in the stores of ancient national poetry, his " (ientle Shepherd," with its simple and exquisite charm, gives him a unique place among the pastoral poets of all time.

\section{ELEGY ON MAGGIE JOHNSTON.}

AULd REEkiE', mourn in sable hue,

1 Edinburgh.

Let fouth= o' tears dreep like May-dew: zabundance.

To braw tippeny ${ }^{3}$ bid adieu, 3 twopenny ale.

Which we wi' greed

Bended ${ }^{4}$ as fast as she could brew,

+ irank.

But, ah! she's dead. 
beat.

$=$ crowd.

3 shoemakers.

4 forthwith.

5 coppers.

${ }^{6}$ ale.

7 Choose your bone (i.e. die).
To tell the truth now, Maggie dang ${ }^{1}$, $O^{\prime}$ customers she had a bang ${ }^{2}$; For lairds and souters ${ }^{3} a^{\prime}$ did gang To drink bedeen *: The barn and yard was aft sae thrang, We took the green;

And there by dizzens we lay down; Syne sweetly ca'd the healths aroun', To bonny lasses, black or brown, As we lo'ed best :

In bumpers we dull cares did drown, And took our rest.

When in our pouch we fand some elinks, And took a turn o'er Bruntsfield Links, Aften in Maggie's, at high-jinks, We guzzled scuds ${ }^{6}$, Till we could scarce, wi' hale-out drinks, Cast aff our duds.

We drank and drew, and filled again, $O$ wow, but we were blythe and fain: When ony had their count mistane, $O$ it was nice! 'To hear us a' cry, "l'ike ye'r bane? And spell ye'r dice." 
Fu' close we used to drink and rant

Until we did baith glower and gaunt ${ }^{1}$,

y.2w11.

2 hiccup and staminer.

iswollen with

Right $\operatorname{swash}^{3}$ I trow;

'Then o' auld stories we did cant drink.

Whan we were fou.

Whan we were wearied at the gowff,

Then Maggie Johnston's was our howff;

Now a' our gamesters may sit dowff +,

IVi' hearts like lead;

Death wi' his rung rax'd her a yowff ',

And sae she's dead.

5 reached her a whack.

Maun we be forced thy skill to tine,

For which we will right sair repine?

Or hast thou left to bairns o' thine

The pawky knack

$\mathrm{O}$ ' brewing ale a'maist like wine,

That gar'd us crack.

Sae brawly did a pease-scone toast

Biz i' the queff 7 , and fley ${ }^{8}$ the frost:

There we got fou wi' little cost,

And meikle speed;

Now, wae worth I Death9! our sport's a' lost, 
Ae summer nicht I was sae fou, Amang the rigs I gaed to spue,

I strip of land.

2 breathed heavily.

Syne down on a green bawk', I trow,

I took a nap,

And soucht ${ }^{2}$ a' night balillilow,

As sound's a tap.

3 began.

4 raised rustling.

5 scare-crow.

And when the dawn begouds to glow,

I hirsled t up my dizzy pow,

Frae 'mang the corn, like wirricow 5 ,

Wi' banes sae sair,

And kenn'd nae mair than if a ewe

How I cam' there.

6 mashing-vat.

Some said it was the pith o' broom

7 fume.

8 chopin-measure did empty.

That she stow'd in her masking-loom ${ }^{6}$,

Which in our heads raised sic a foum ${ }^{7}$;

Or some wild seed,

Which aft the chappin-stoup did toom ${ }^{\circ}$,

But filled our head.

But now since it's sac that we must

Not in the best ale put our trust,

But whan we're auld return to dust,

Without remead,

Why should we tak' it in disgust

'That Maggie's dead? 
O' warldly comforts she was rife, And lived a lang and hearty life, Right free o' care, or toil, or strife, Till she was stale,

And kenn'd to be a canny' wife At brewing ale.

Then fareweel, Maggic, douce and fell ${ }^{2}$,

O' brewers a' thou boor the bell:

Let a' thy gossips yelp and yell, And, without feid,

Guess whether ye're in heaven or hell.

'They're sure ye're dead. 


\section{PATIFS SONG.}

(THE GENTLE SHFPHERH, SCENE I.)

Mr Peggy is a young thing Just entered in her teens,

Fair as the day, and sweet as May-Fair as the day, and always gay.

My Peggy is a young thing. And I'm na very auld:

Yet weel I like to meet her at The wauking o' the fauld.

My Peggy speaks sat sweetly Whene'er we meet alane.

I wish nae mair to lay my care-

I wish nae mair o' a' that's rare.

My Peggy speaks sae swectly, To a' the lave I'm cauld: But she gars o' my spirits glow At wauking o' the fauld.

My Peggy smiles sae kindly

Whene'er I whisper love, That I look doun on a' the toun That I look doun upon a croun. 
My l'eggy smiles sae kindly

It mak's me blythe and bauld;

And naething gie's me sic delight

As wauking o' the fauld.

My Peggy sings sae saftly

When on my pipe I play,

13y $a^{\prime}$ the rest it is confessed-

By a' the rest--that she sings best.

My Peggy sings sae saftly,

And in her sangs are tald

Wi' innocence the waler o' sense,

1 choicest.

At wauking o' the fauld.*

* The watching of the fold was a necessily for several nights annually at weaning time. To this duty it was usual to set apart a couple who were understool to be kindly inclined to each other; and the opportunity was in especial favour among pastoral lovers. 


\section{PEGGY ANI) JENNY.}

(THE GeNTLF. SHEPHERD, SCENF, II.)

A flowerie howm, between twa verdant bracs, Where lasses use to wash and spreal their claes, A trotting burnie wimpling through the ground, Its channel pebbles shining smooth and round: Ilere view twa barcfool beaulies, clean and clear; First please your eye, next gratify your ear: While Jenny what she wishes discommends, And Meg, wi' better sense, true love defends.

\section{Jenny.}

Come, Meg, let's fa' to wark upon this green, This shining day will bleach our linen clean;

I sky. 'The water's clear, the lift ${ }^{\mathrm{r}}$, unclouded blue, will mak' them like a lily wet wi' dew.

\section{Pegry.}

= Hollow. Gae farer up the burn to Habbie's Howe ${ }^{2}$, Where a' the sweets o' spring and simmer grow:

Between twa birks, out o'er a little linn, The water fa's and mak's a singin' din:

A pool breast-deep, beneath as clear as glass, Kisses, wi easy whirls, the bordering grass.

We'll end our washing while the morning's cool; And when the day grows het we'll to the pool, 
There wash oursels-'tis healthfu' now in May, And sweetly cauler ${ }^{2}$ on sae warm a day.

\section{Jenny.}

Daft lassie, when we're naked, what'll ye say

Gif our twa herds come brattling ${ }^{2}$ down the brac, "clattering. And see us sae? that jeering fallow Pate, Wad taunting say, "Haith lasses, ye're no blate 3 !" 3 bastrul.

\section{Pegsy.}

We're far frae ony road, and out o' sight;

'The lads they're feeding far beyont the height.

But tell me, now, dear Jenny, we're our lane,

What gars ye plague your wooer wi' disdain?

The neibours a' tent 4 this as weel as I,

4 note.

That Roger lo'es ye, yet ye carena by.

What ails ye at him? Troth, between us twa,

He's wordy you the best day e'er ye saw.

\section{Jenny.}

I dinna like him, Peggy; there's an end.

A herd mair sheepish yet I never ken'd.

He kaims his hair, indeed, and gaes right snug,

Wi ribbon knots at his blue bannet lug,

Whilk pensilic he wears a thought a-jee,

And spreads his gartens diced beneath his knee.

He falds his o'erlay 5 down his breast wi' care,

5 neck-cloth.

And few gangs trigger ${ }^{6}$ to the kirk or fair :

6 smarter.

For a' that, he can neither sing nor say;

Except, "How d'ye?" or "There's a bomie day." 


\section{Peggy.}

Ye dash the lad wi' constant slighting pride;

Hatred for love is unco sair to bide.

But ye'll repent ye if his love grow cauld:

1 saucy. What like's a dorty maiden when she's auld?

Like dawted ${ }^{2}$ wean, that tarrows 3 at its meat,

${ }^{t}$ rest.

The lave ${ }^{6}$ laugh at it, till the dinner's past;

And syne the fule thing is obliged to fast,

Or scart anither's leavings at the last.

Fy! Jenny, think, and dinna sit your time.

\section{Jenny.}

I never thought a single life a crime.

\section{Peroy.}

Nor I. But love in whispers lets us ken

That men were made for us, and we for men.

\section{Jenny.}

If Roger is my jo, he kens himsel',

For sic a tale I never heard him tell.

He glowers and sighs, and I can guess the cause;

But wha's obliged to spell his hums and haws?

Whene'er he likes to tell his mind mair plain,

I'se tell him frankly ne'er to do't again.

They're fules that slavery like, and may be free; The chiels7 may a' knit up themsel's for me.

\section{Pessy.}

Be doing your wa's; for me I ha'e a mind To be as yielding as my Patie's kind. 


\section{Jenny.}

Heh, lass! how can ye lo'e that rattle-skull?

A very deil, that aye maun ha'e his will.

We'll soon hear tell what a puir fechting life

You twa will lead, sae soon's ye're man and wife.

\section{Peggy.}

I'll rin the risk, nor ha'e I ony fear,

But rather think ilk langsome day a year,

'Till I wi' pleasure mount my bridal bed,

Where on my Patie's breast I'll lean my head.

'There we may kiss as lang as kissing's guid,

And what we do, there's nane daur ca' it rude.

He's get his will. Why no? It's good my part

'To gi'e him that, and he'll gi'e me his heart.

\section{Jenny.}

He may indeed, for ten or fifteen days,

Mak' meikle o' ye, wi' an unco fraise ${ }^{\text {, }}$

And daut ye baith afore folk, and your lane.

But soon as his newfangleness is gane,

He'll look upon you as his tether-stake,

And think he's tint ${ }^{2}$ his freedom for your sake. =loit.

Instead then o' lang days o' sweet delight,

Ae day be dumb, and a' the neist he'll flyte ${ }^{3}$

And maybe, in his barlickhoods 4 , ne'er stick

To lend his loving wife a loundering lick.

3 icokl.

4 fits of violent illhumour.

\section{Peggy.}

Sic coarse-spun thoughts as thae want pith to move My settled mind; I'm o'er far gane in love.

Patie to me is dearer than my breath, 
But want o' him I dread nae other skaith.

There's nane o' a' the herds that tread the green

Has sic a smile, or sic twa glancing een:

And then he speaks wi' sic a taking art,

His words they thirl like music through my heart.

How blithely can he sport, and gently rave,

And jest at feckless fears that fright the lave!

Ilk day that he's alane upon the hill,

' wonderful. He reads fell ' books that teach him meikle skill;

$\mathrm{He}$ is-but what need I say that or this?

I'd spend a month to tell ye what he is!

z manner. In a' he says or does there's sic a gate ${ }^{2}$,

3 nimies. The rest seem cuifs ${ }^{3}$ compared wi my dear Pate.

His better sense will lang his love secure;

4 dwells. Ill-nature hefts ${ }^{4}$ in sauls that's weak and puir.

5 whining children. Syne whinging getts 5 about your ingle-side,

${ }^{6}$ troublesome. Yelping for this or that wi' fashous ${ }^{6}$ din:

7 pinafores. To mak' them brats ${ }^{7}$ then ye maun toil and spin.

8scaldsitselfwith Ae wean fa's sick, ane scads itsel' wi' broe ${ }^{8}$,
soup.

Ane breaks his shin, anither tines his shoe;

The Deil gaes o'er Jock Wabster, hame grows hell, And Pate misca's ye waur than tongue can tell.

\section{Pesgy.}

Yes it's a heartsome thing to be a wife,

When round the ingle-edge young sprouts are rife. 
(iif I'm sae happy, I shall ha'e delight

'To hear their little plaints, and keep them right.

Wow! Jenny, can there greater pleasure be

Than see sic wee tots tulying ${ }^{\boldsymbol{I}}$ at your knee; 'playing.

When a' they ettle ${ }^{2}$ at -their greatest wish, "aim.

Is to be made o', and obtain a kiss?

Can there be toil in tenting day and night

'The like o' them, when love mak's care delight?

\section{Jenny.}

But puirtith, Peggy, is the warst o' a',

Gif o'er your heads ill-chance should begg'ry draw;

But little love or canty cheer can come

Frae duddy 3 doublets, and a pantry toom 4.

Your now ${ }^{5}$ may die;-the spate may bear away 5 cattle.

Frae aff the howms your dainty rucks o' hay.

The thick-blawn wreath o' snaw, or blashy thows ${ }^{6}$, ${ }^{6}$ deluging thaws.

May smoor 7 your wathers, and may rot your ewes. 7 smother.

A dyvour ${ }^{8}$ buys your butter, woo', and cheese, 8 bankrupt.

But, or the day o' payment, breaks and flees :

Wi' gloomin' brow, the laird seeks in his rent;

It's no to gi'e; your merchant's to the bent:

His honour maunna want; he poinds your gear:

Syne, driven frae house and hald, where will ye steer?

Dear Meg, be wise, and live a single life;

Troth, it's nae mows9 to be a married wife. 9 play.

\section{Pegrgy.}

May sic ill luck befa' that silly she

Wha has sic fears, for that was never me.

Let folk bode ${ }^{10}$ weel, and strive to do their best; ${ }^{20}$ plan 
Nae mair's required; let Heaven mak' out the rest.

I've heard my honest uncle aften say

That lads should a' for wives that's virtuous pray;

For the maist thrifty man could never get

A weel-stored room, unless his wife wad let:

Wherefore nocht shall be wanting on my part,

To gather wealth to raise my shepherd's heart:

Whate'er he wins I'll guide wi' canny care,

And win the vogue at market, tron, or fair, For halesome, clean, cheap, and sufficient ware.

A flock o' lambs, cheese, butter, and some woo', Shall first be sald, to pay the laird his due; Syne a' behind's our ain. Thus, without fear,

slenty. Wi' love and rowth ${ }^{x}$, we through the warld will steer: And when my Pate in bairns and gear grows rife, He'll bless the day he gat me for his wife.

\section{Jenny.}

2 wanton wench. But what if some young giglet ${ }^{2}$ on the green, 'Wi' dimpled cheeks and twa bewitching een, Should gar your Patie think his half-worn Megr,

3 tig. And her ken'd kisses, hardly worth a feg 3 ?

\section{Pegogy.}

Nae mair o' that! Dear Jenny, to be free, 'There's some men constanter in love than we.

- marvel. Nor is the ferly+ great, when nature kind Has blest them wi solidity of mind.

'They'll reason calmly, and wi' kindness smile, When our short passions wad our peace beguile: 
It's ten to ane the wives are maist to blame. 'Then I'll employ wi' pleasure a' my art 'ro keep him cheerfu', and secure his heart. At e'en, when he comes weary frae the hill, I'll ha'e a' things made ready to his will. In winter when he toils in wind and rain, A bleczing ingle, and a clean hearth-stane; And soon as he flings by his plaid and staff, The seething pat's be ready to tak' aff; Clean hag-a-bag' I'll spread upon his board, And serve him wi' the best we can afford; Good humour and white bigonets ${ }^{2}$ shall be Guards to my face, to keep his love for me.

1 coarse table. linen.

2 linen caps.

\section{Jenny.}

A dish o' married love right soon grows cauld, And dosens ${ }^{3}$ down to nane as folk grow auld.

\section{Pegry.}

But we'll grow auld thegither, and ne'er find 'The loss o' youth, when love grows on the mind.

Bairns and their bairns mak' sure a firmer tie, 'Than aught in love the like o' us can spy. See yon twa elms that grow up side by side, Suppose them, some years syne, bridegroom and bride;

Nearer and nearer ilka year they've prest, Till wide their spreading branches are increased, And in their mixture now are fully blest: This shields the other frae the eastlin blast, That, in return, defends it frae the wast. 
Sic as stand single (a state sae liked by you !)

Beneath ilk storm, frae every airt, maun bow.

\section{Jenny.}

I've done-I yield, dear lassie, I maun yield:

Your better sense has fairly won the field, With the assistance of a little fae

I.ies darned within my breast this mony a day.

\section{Peggy.}

Alake, poor pris'ner! Jenny, that's no fair, That ye'll no let the wee thing tak' the air: Haste, let him out; we'll tent as weel's we can. Gif he be Bauldy's or puir Roger's man.

\section{Jenny.}

Anither time's as gude-for, see, the sun Is right far up, and we're not yet begun

- To make ready To freath the graith ${ }^{\mathrm{T}}$. If canker'd Madge, our aunt, the soapy water for washing.

Come up the burn, she'll gie's a wicked rant: But when we've done, I'll tell ye a' my mind; For this seems true--nae lass can be unkind. 


\section{EPISTLE TO WILLIAM IAMILTON OF GILBERTFIELD.}

Eminumgil, September 2, 1719.

My Trusty Trojan,

Thy last oration orthodox,

Thy innocent auldfarren ${ }^{x}$ jokes,

And sonsie ${ }^{2}$ saw o' three, provokes

Me ance again,

'Tod-lowrie 3 like, to lowse my pocks,

$\checkmark$ sagacius.

2 comely, good. humoured.

3 Reynard.

And pump my brain.

By a' your letters I ha'e read,

I eithly 4 scan the man weel-bred, And soger that, where honour led,

Has ventured bauld.

Wha now to youngsters leaves the yed5, To 'tend his fauld.

That bangster billy, Cæesar July, 6 violent fellow.

Wha at Pharsalia wan the tulye?, 7 strife.

Had better sped, had he mair hoolie ${ }^{8}$ 8 softly.

Scampered through life,

And 'midst his glories sheathed his gully,

And kissed his wife. 
Had he, like you, as weel he could,

Upon burn banks the muses wooed, Retired betimes frae 'mang the crowd, Wha'd been abune him?

The senate's dirks, and faction loud, Had ne'er undone him.

I covert.

Yet sometimes leave the riggs and bog, Your howms, and braes, and shady scrog ${ }^{\mathrm{T}}$, And helm-a-lee the claret cog,

To clear your wit;

Be blithe, and let the warld e'en shog As it thinks fit.

Ne'er fash about your neist year's state, Nor wi' superior powers debate,

2 charms.

Nor cantrips ${ }^{2}$ cast to ken your fate;

'There's ills eneu'

To cram our days, which soon grow late;

Let's live just now.

3 hollows look stormy,
When northern blasts the ocean snurl, And gar the heights and howes look gurl 3, Then left about the bumper whirl, And toom the horn:

Grip fast the hours which hasty hurl:

'The morn's the morn. 
Thus to Leuconoe sang sweet Flaccus,

Wha nane e'er thought a gillygapus ${ }^{\mathrm{x}}$ :

And why should we let whimsies balk us,

When joy's in season,

And thole ${ }^{2}$ sae aft the spleen to whauk us

Out o' our reason?

'Though I were laird o' ten-score acres,

Nodding to jouks o' hallenshakers ${ }^{3}$,

3 bowing louts y

Yet crushed wi' humdrums, which the weaker's

Contentment ruins,

I'd rather roost wi' causey-rakers,

And sup cauld sowens4.

I think, my friend, an folk can get

A dole of roast beef pipin' het,

And wi' red wine their wyson 5 wet,

5 thruat.

And claithing clean,

And be na sick, or drowned in debt,

They're no to mean ${ }^{6}$.

6 lament for.

I read this verse to my ain kimmer ${ }^{7}$,

7 comrade.

Wha kens I like a leg o' gimmer,

8 two-year-o!ci

Or sic and sic, guid belly-timmer; cue.

Quoth she, and leugh,

"Siccar 9 o' thae, winter and simmer,

Ye're weel eneuch." 
gossip.

2 fist.

$3_{4}$ hearty, merry.

4 hand-picked.

5 shrewd.

6 become eager.

7 laughing violently.
My hearty goss ${ }^{\mathrm{x}}$, there is nae help,

But hand to neive ${ }^{2}$ we twa maun skelp Up Rhine and Thames, and o'er the Alpines and Pyrenians:

The cheerfu' carles do sae yelp

T' hae's their minions.

Thy raffan ${ }^{3}$ rural rhyme sae rare,

Sic wordy, wanton, hand-waled + ware, Sae gash 5 and gay, gars folk gae gare ${ }^{6}$

To ha'e them by them;

'Though gaffin'? they, wi' sides sae sair, Cry, "Wae gae by him."

Fair fa' that sodger did invent

To ease the poet's toil wi' prent:

Now, William, we maun to the bent, ${ }^{8}$ push. And pouse ${ }^{8}$ our fortune, And crack wi' lads wha're weel content Wi' this our sporting.

(in ony sour-mou'd girning bucky Ca' me conceity keckling chucky, 9 itchy. That we like nags whase necks are yucky', Ha'e used our teeth; I'll answer fine, "Gae kiss your I.ucky, She dwells i' Leith." 
EPISTLE TO WILLIAM HAMILTON. GI

I ne'er wi' lang tales fash my head, But when I speak, I speak indeed: Wha ca's me droll, but ony feid ${ }^{x}$,

I'll own I am sae: offence.

And while my champers can chew bread, Yours, AllaN R.MSAY. 


\section{LOCHABER NO MORE.}

FAREwell to Lochaber, and farewell my Jean, Where heartsome wi' thee I've mony day been; For Lochaber no more, Lochaber no more, We'll maybe return to Lochaber no more. 'These tears that I shed, they are a' for my dear, And no for the dangers attending on weir ${ }^{\mathrm{I}}$, Though borne on rough seas to a far bloody shore, Maybe to return to I.ochaber no more.

Though hurricanes rise, and rise every wind, 'They'll ne'er mak' a tempest like that in my mind; 'Though loudest o' thunders on louder waves roar, 'That's naething like leaving my love on the shore. To leave thee behind me my heart is sair pained: By ease that's inglorious no fame can be gained: And beauty and love's the reward o' the brave, And I must deserve it before I can crave.

Then glory, my Jeanie, maun plead my excuse; Since honour commands me, how can I refuse? Without it I ne'er can have merit for thee; And without thy farour I'd better not be. I gae, then, my lass, to win honour and fame, And if I should luck to come gloriously hame, I'll bring a heart to thee wi' love running o'er, And then I'll leave thee and Lochaber no more. 


\section{THE YOUNG LAIRD ANI) EDINBURGH KATIE.}

Now wat ye wha I met yestreen

Coming down the street, my jo?

My mistress in her tartan screen,

Fu' bonnie, braw, and sweet, my jo.

"My dear," quoth I, "thanks to the night

That never wished a lover ill;

Since ye're out o' your mither's sight,

Let's tak' a walk up to the hill.

"O Katie, wiltu gang wi' me,

And leave the dinsome town a while?

The blossom's sprouting frae the tree,

And a' the simmer's gaen to smile.

'The mavis, nightingale, and lark,

'The bleating lambs and whistling hind,

In ilka dale, green shaw, and park,

Will nourish health and glad ye'r mind.

"Soon as the clear guidman o' day

Ioes bend his morning draught o' dew,

We'll gae to some burn-side and play,

And gather flowers to busk your brow. 
' globe-flowers, cabbage-daisies.

2 moss.
We'll pu' the daisies on the green, The lucken-gowans $x$ frae the bog;

Between hands now and then we'll lean, And sport upon the velvet $f_{0}{ }^{2}$.

"There's up into a pleasant glen, $A$ wee piece frae my father's tower,

A canny, saft, and flowery den, Which circling birks ha'e formed a bower:

Whene'er the sun grows high and warm, We'll to the cauler shade remove, There will I lock thee in my arm, And love and kiss, and kiss and love." 


\section{UP IN THE AIR.}

Now the sun's gane out o' sight,

Beet the inglex, and snuff the light:

I niend the fire.

In glens the fairies skip and dance,

And witches wallop o'er to France,

$\mathrm{Up}_{\mathrm{p}}$ in the air

On my bonnie grey mare;

And I see her yet, and I see her yet.

The wind's drifting hail and snaw

O'er frozen hags ${ }^{2}$ like a foot-ba',

2 broken, pitted

Nae starns keek ${ }^{3}$ through the azure slit, mosshands.

It's cauld and mirk 4 as ony pit.

The man i' the moon

Is carousing abune,

I'ye see, d'ye see, d'ye see him yet?

Tak' your glass to clear your een,

It's the elixir heals the spleen;

Baith wit and mirth it will inspire, And gently puffs the lover's fire.

Up i' the air,

It drives away care,

Ha'e wi' ye, ha'e wi' ye, and ha'e wi' ye, lads, yet. 


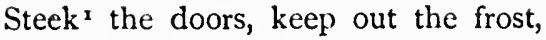
Come, Willy, gie's about your toast, Till't lads, and lilt it out, And let us ha'e a blythsome bout.

Up wit there, there, Dinna cheat, but drink fair, Huzza, huzza, and huzza, lads, yet! 


\section{THE WIDOIV.}

THE widow can bake, and the widow can brew,

The widow can shape, and the widow can sew, And mony braw things the widow can do;

Then have at the widow, my laddie!

W'i' courage attack her baith early and late;

'To kiss her and clap her ye maunna be blate:

speak weel, and do better: for that's the best gater way.

To win a young widow, my laddie.

'The widow she's youthfu', and never ae hair

'The waur o' the wearing, and has a guid skair ${ }^{2}{ }^{2}$ shar

$O$ ' everything lovely; she's witty and fair,

And has a rich jointure, my laddie.

What could ye wish better, your pleasure to crown,

Than a widow the bonniest toast in the town,

Wi' naething but draw in your stool and sit down,

And sport wi' the widow, my laddie?

Then till 3 her, and kill her wi' courtesy dead, 310.

Though stark love and kindness be a' ye can plead;

Be heartsome and airy, and hope to succeed

Wi' a bonnie gay widow, my laddie.

Strike iron while it's het, if ye'd have it to wald;

For fortune aye favours the active and bauld,

But ruins the wooer that's thoughtless and cauld,

Unfit for the widow, my laddie. 


\section{ROBERT CRAWFORD.}

\section{I695-1 $73^{2}$.}

Among the "ingenious young gentlemen" who were contributors to the Tea-Table Miscellany in 1724, one of the most distinguished was Robert Crawford. Four songs in that collection--"The Bush abune Traquair," "The Broom of the Cowdenknowes," "One day 1 heard Mary say," and "My Dearie, if thou dee"-were from his pen, while a fifth, entitled "Sweet Susan," is generally ascribed to him; and to the Orpheus Caledonius, published shortly afterwards, he contributed other three-"Tweedside," "Doun the burn, Davie lad," and "The bonniest lass in a' the warld." In Johnson's Musical Museum there is also a song by Crawford, set to the tune of "Allan Water."

Nearly all that is known of the poet is given by Chambers in his Songs of Scotland, prior to Bums. Crawford was the second son of Patrick Crawford of Drumsoy in Renfrewshire. His elder brother Thomas acted as secretary to the embassy to France under Lord Stair, and was afterwards appointed Envoy Extraordinary to the French Court. It was probably owing to this fact that Robert Crawford spent several years in France; and he is understood to have died in returning from that country in 1732 . Little is known of the personality of the poet. Ramsay of Ochtertyre, writing to Burns in $17 \mathrm{~S}_{7}$, mentions that he had just conversed with a Colonel Edmondstone, a cousin of Robert Crawford, who rememlered attencling the poet's funeral fifty-five years before. "Crawford," said Etlmondstone in the cant phrase of the time, "was a pretty young man."

Of the songs by this pretty gallant in the Orpheus Caledonizs two were addressed to ladies. "The bonniest lass in a' the warld" was indited to Miss Anne Hamilton, and "Tweedside," the poet's best-known piece, is believed by tradition to have had for its olject Miss Mary Scott, second daughter of John Scott of Harden. Colonel Edmondstone, it is true, stated that the latter song was addressed to a Mary Stewart of the Castlemilk family, but internal evidence seems to be against this supposition, and a remark of Sir Walter Scott makes the matter certain. Whether or not anything more than mere poetic feeling underlay either of these compositions can hardly now be discovered; lut when the Orpheus Caledonizs appeared in 1725 Mary scott must have been in her freshest bloom. An earlier Mary Scott, daughter of Scott of Dryhope of the time of 
Queen Mary, who married Walter Scott of Harden, had been called the Flower of Yarrow, and celebrated in a song of which four verses alone remain:-

$$
\begin{aligned}
& \text { Mary's black and Mary's white; } \\
& \text { Mary is the king's delight- } \\
& \text { The king's delight, the prince's marrow: } \\
& \text { Mtary Sict, the Flower of Y'arrow. }
\end{aligned}
$$

To the air of this, Allan Ramsay composed a new song on her rescendant, to whom he also gave the title of the Flower of Yarrow. Allan Ramsay, junior, painted a portrait of the lady, which hangs in Iamilton I'alace. But, whether her heart w'as set on the dead poet of the Orpheus Cialedonizs, or, among the press of suitors, she found herself unable to make a choice, Mary Scott remained unmarried. Sir Walter Sentt in his autobiographical fragment states that he remembered meeting in his early youth the once famous F.dinlurgh belle. "I remember her," he writes, "as an old lady distinguished for elegant manners and high spirit, though struggling with the disadvantage: of a narrow income, as her father's estate, being entailed on heirs-male, went to another branch of the Harden family. I have heard a hundred times, from those who lived at the time, that 'Tweelside' and 'Mary Scott the Flower of Yarrow' were both written upon this much admired lady."

Curiously, as Crawford was anticipated in the title of his bestknown piece by the "Tweedside" of Lord Yester, and in that of his "Broom of Cowdenknowes" by one of the finest of the ancient ballads, his own "Bush abune Traquair" has had its title infringed by the later and very beatiful ballad of Principal Shairp.

\section{TWEEDSIDE.}

What beauties does Flora disclose:

How sweet are her smiles upon Tweed!

l'et Mary's, still sweeter than those,

Both nature and fancy exceed.

No daisy, nor sweet blushing rose,

Not all the gay flowers of the field,

Not Tweed, gliding gently through those,

Such beauty and pleasure does yield. 
The warblers are heard in the grove,

The linnet, the lark, and the thrush;

The blackbird and sweet cooing dove

With music enchant every bush.

Come, let us go forth to the mead;

Let us see how the primroses spring!

We'll lodge in some village on Tweed,

And love, while the feathered folk sing.

How does my love pass the long day?

Does Mary not tend a few sheep?

Do they never carelessly stray

While happily she lies asleep?

Should Tweed's murmurs lull her to rest,

Kind nature indulging my bliss,

To ease the soft pains of my breast

I'd steal an ambrosial kiss.

'Tis she does the virgins excel;

No beauty with her may compare:

Love's graces around her do dwell:

She's fairest where thousands are fair.

Say, charmer, where do thy flocks stray?

$\mathrm{Oh}$, tell me at noon where they feed?

Shall I seek them on sweet-winding Tay,

Or the pleasanter banks of the liweed? 


\section{THE BUSH ABUNE TRAQUAIR.}

Hear me, ye nymphs and every swain, I'll tell how Peggy grieves me; Though thus I languish and complain, Alas! she ne'er believes me.

My vows and sighs, like silent air Unheeded, never move her; At the bonnie bush abune Traquair, 'Twas there I first did love her.

That day she smiled and made me glad, No maid seemed ever kinder;

I thought myself the luckiest lad, So sweetly there to find her.

I tried to soothe my amorous flame In words that I thought tender; If more there passed I'm not to blameI meant not to offend her.

Yet now she, scornful, flees the plain, The fields we then frequented; If e'er we meet she shews disdain, She looks as ne'er acquainted. 
The bonnie bush bloomed fair in May,

Its sweets I'll aye remember;

But now her frowns make it decay-

It fades as in December.

Ye rural powers who hear my strains, Why thus should Peggy grieve me?

$\mathrm{O}$ make her partner in my pains,

Then let her smiles relieve me.

If not, my love will turn despair,

My passion no more tender;

I'll leave the bush abune Traquair, To lonely wilds I'll wander. 


\section{DOUN THE BURN, DAVIE.}

When trees did bud, and fields were green, And broom bloomed fair to see,

When Mary was complete fifteen, And love laughed in her e'e, Blyth Davie's blinks' her heart did move "glances. To speak her mind thus free, "Gang doun the burn, Davie love, And I shall follow thee."

Now Iavie did each lad surpass

That dwelt on this burnside. And Mary was the bonniest lass, Just meet to be a bride.

Her cheeks were rosy, red and white, Her e'en were bonnie blue, Her looks were like Aurora bright, Her lips like dropping dew.

As down the burn they took their way,

What tender tales they said;

His cheek to hers he aft did lay

And with her bosom played. 
Till baith at length impatient grown To be mair fully blest,

In yonder vale they leaned them downLove only saw the rest.

What passed, I guess was harmless play, And naething, sure, unmeet, For ganging hame I heard him say They liked a walk sae sweet, And that they aften should return Sic pleasure to renew.

Quoth Mary, "Love, I like the burn, And aye shall follow you." 


\section{ROBERT BLAIR.}

\section{699-1 746 .}

Of an equal boldness with Ramsay in departing from the conventions of the school of Pope, but at the same time of a very different spirit from the author of "The Gentle Shepherd," was Robert Blair. As Ramsay was the chief exponent of Scottish humour of the time, Blair may be regarded as the apostle of melancholy. IIis work, with its rude pathos, strength, and keen feeling for nature, remains typical of the darker side of the Scottish spirit.

Grandson of Robert Blair, the celelsated Covenanter, and eldest son of a minister of the same name in Edinburgh, the poet was educated at Edinburgh University, and travelled for a time on the continent, before settling as minister of $\lambda$ thelstaneford in IIaddingtonshire in 173I. Ilis first printed verses appeared in the Edinburgh Miscellany in 1720, and he was the author of several pieces, but his sole title to remembrance is his chief poem, "The Grave." This was begun before his settlement at Athelstaneford, but was not published till 1743 . The poem was long poptular, and if the rhythm does not always appear entirely harmonious, the imagery is vigorous and unhackneyed, and the style in admirable keeping with the subject. In more than one of the passages, as that on the gravedigger and on the question of a hereafter, the inspiration appears obviously Shakespearean : but the main conception is entirely original, the number of quoted phrases in a piece of no more than 750 lines is remarkable, and the final passage, the best thing Blair wrote, expresses worthily the spirit of triumphant Christian philosophy- "O Death, where is thy sting? O Grave, where is thy victory?" One of Blair's lines, that of visits "like those of angels short and far between," remains familiar in the form in which it was repeated and spoiled by Campbell.

The poet died of fever on February 4, 1746, and was succeeded in his charge by John I Iome, author of the tragedy of "Douglas." Blair's wife was a daughter of Mr. Law of Elvingston, Professor of Moral Philosophy at Edinlurgh University, a lovely and amiable woman, by whom he had five sons and a danghter. His fourth son afterwards became President of the Court of Siession. Among numerous editions of Blair's work, that illustrated by William Blake, and published by Cromek in I80\$, remains specially notable. 


\section{THE GRAVE.}

Whilst some affect the sun, and some the shade, Some flee the city, some the hermitage, Their aims as various as the roads they take In journeying through life; - the task be mine To paint the gloomy horrors of the tomb, Th' appointed place of rendezvous, where all These travellers meet. Thy succours I implore, Eternal King! whose potent arm sustains The keys of hell and death.

The Grave, dread thing !

Men shiver when thou'rt named: Nature, appalled, Shakes off her wonted firmness. Ah, how dark Thy long-extended realms and rueful wastes, Where nought but silence reigns, and night, dark night,

Dark as was chaos ere the infant sun

Was rolled together, or had tried its beams

Athwart the gloom profound! The sickly taper

By glimm'ring through the low-browed, misty vaults, Furred round with mouldy damps and ropey slime, Lets fall a supernumerary horror, And only serves to make the night more irksome. Well do I know thee by thy trusty yew, 
Cheerless, unsocial plant! that loves to dwell 'Midst skulls and coffins, epitaphs and worms, Where light-heeled ghosts and visionary shades, Beneath the wan cold moon, as fame reports, Embodied thick, perform their mystic rounds. No other merriment, dull tree! is thine.

See yonder hatlowed fane! the pious work Of names once famed, now dubious or forgot, And buried midst the wreck of things that were: There lie interred the more illustrious dead. The wind is up: hark! how it howls! methinks Till now I never heard a sound so dreary.

Doors creak, and windows clap, and night's foul bird, Rooked in the spire, screams loud. 'The gloomy' aisles,

Black-plastered and hung round with shreds of scutcheons

And tattered coats of arms, send back the sound, Laden with heavier airs from the low vaults, The mansions of the dead. Roused from their slumbers,

In grim array the grisly spectres rise, Grin horrible, and, obstinately sullen, Pass and repass, hushed as the foot of night.

Again the screech-owl shrieks-ungracious sound: I'll hear no more; it makes one's blood run chill.

[The supernatural terrors of the churclyard are described, the pangs of widowed love, and the dear memories of friendship.]

Dull Grave! thou spoil'st the dance of youthful blood, 
Strik'st out the dimple from the cheek of mirth, And ev'ry smirking feature from the face;

Branding our laughter with the name of madness.

Where are the jesters now?-the men of health,

Complexionally pleasant? Where the droll

Whose ev'ry look and gesture was a joke

To clapping theatres and shouting crowds,

And made even thick-lipped, musing Melancholy

To gather up her face into a smile

Before she was aware? Ah, sullen now,

And dumb as the green turf that covers them!

Where are the mighty thunderbolts of war,

The Roman Cæsars and the Grecian chiefs,

The boast of story? Where the hot-brained youth

Who the tiara at his pleasure tore

From kings of all the then discovered globe,

And cried, forsooth, because his arm was hampered

And had not room enough to do its work?

Alas! how slim, dishonourably slim,

And crammed into a space we blush to name!

Proud royalty! how altered in thy looks,

How blank thy features, and how wan thy hue!

Son of the morning! whither art thou gone?

Where hast thou hid thy many-spangled head,

And the majestic menace of thine eyes

Felt from afar?

[A royal funeral is described, and the futility of human fame descanted on. In turn the grave is made to furnish a lesson to beauty, strength, and learning; the orator, the physician, and the hoarder of wealth are each warned of the end that waits them. The soul is brought to face the eternal gulf, and the question asked of a hereafter. The folly of pride is pointed out, for 
tyrant and slave, prude and coquette, alike lie forgotten under. ground. Man's first estate is dwelt on, and the effects of the coming of sin, then the work of Christ and the triumph of the human spirit over death and the grave. The poem ends with a diatribe on the folly of the fear of death.]

We wish to be where sweets unwithering bloom;

But straight our wish revoke and will not go.

So have I seen, upon a summer's even,

Fast by the riv'let's brink a youngster play.

How wishfully he looks to stem the tide!

This moment resolute, next unresolved.

At last he dips his foot; but as he dips,

His fears redouble, and he runs away

From th' inoffensive stream, unmindful now

Of all the flowers that paint the further bank

And smiled so sweet of late. Thrice welcome Death!

'That after many a painful, bleeding step,

Conducts us to our home, and lands us safe

On the long-wished-for shore. Prodigious change :-

Our bane turned to a blessing! Death, disarmed, Loses his fellness quite; all thanks to Him

Who scourged the venom out. Sure the last end

Of the good man is peace! How calm his exit!

Night-dews fall not more gently to the ground,

Nor weary, worn-out winds expire so soft.

Behold him in the evening-tide of life-

A life well spent, whose early care it was

His riper years should not upbraid his green-

By unperceived degrees he wears away,

Yet, like the sun, seems larger at his setting.

High in his faith and hopes, look how he reaches

After the prize in view, and like a bird 
That's hampered, struggles hard to get away; Whilst the glad gates of sight are wide expanded To let new glories in, the first fair fruits Of the fast-coming harvest. Then, oh! then Each earth-born joy grows vile, or disappears, Shrunk to a thing of nought. Oh how he longs To have his passport signed, and be dismissed! 'Tis done, and now he's happy; the glad soul Has not a wish uncrowned. F'en the lag flesh Rests too in hope of meeting once again Its better half, never to sunder more.

Nor shall it hope in vain; the time draws on When not a single spot of burial earth, Whether on land or in the spacious sea, But must give back its long committed dust Inviolate; and faithfully shall these Make up the full account, not the least atom Embezzled or mislaid, of the whole tale. Each soul shall have a body ready furnished; And each shall have his own. Hence, ye profane! Ask not how this can be! Sure the same Power That reared the piece at first, and took it down, Can reassemble the loose scattered parts, And put them as they were. Almighty (rod Hath done much more; nor is his arm impaired Through length of days; and what he can he will. His faithfulness stands bound to see it done.

When the dread trumpet sounds, the slumb'ring dust Not unattentive to the call, shall wake, And every joint possess its proper place With a new elegance of form unknown 
To its first state. Nor shall the conscious soul Mistake its partner, but amidst the crowd Singling its other half into its arms Shall rush, with all th' impatience of a man 'That's new come home, and, having long been absent,

With haste runs over every different room,

In pain to see the whole. Thrice happy meeting! Nor time nor death shall ever part them more.

'Tis but a night, a long and moonless night; We make the grave our bed, and then are gone. Thus, at the shut of even, the weary bird Leaves the wide air, and in some lonely brake Cowers down and doses till the dawn of day, Then claps his well-fledged wings, and bears away. 


\section{THE AUTHOR OF ALBANIA.}

\section{Fl. $\quad 1737$.}

All that is known of the author of Albania: a Pocm addressed to the Genius of Scotland, is told by Dr. John Leyden in his Iittle volume of Scottish Descriptive Poems (Edin. I803). The author and the original editor, he says, are equally unknown, and of the original edition of the poem, printed at London for T. Cooper, in 1737 , only one copy is known to exist. From the advertisement to that single copy Leyden quotes the sentence, "The poem was wrote by a Scots clergyman, some years ago, who is since dead," and from an allusion in the poem itself the author appears to have been twenty-four years of age at the time of composition. Leyden further quotes a verse of Aaron Hill declaring the author and also the earlier cditor of the poem to have been Scotsmen, and he states that the preservation of the piece is due to the taste of "the ingenious author of The Minstrel." This last fact, and a reference to "Devana" in the body of the piece, point to the conclusion that the poct was a native, or at least a resident, of Aberdeen. Nothing further has heen discovered of the author of Albania, and he seems to have left no other work to the world. Within the short length of its 296 lines, however, the poem contains passages which are hardly surpassed by anything written in its time. It is put together without artistic method, and some of its parts treat of matters hardly suited for poetry; but throughout it has a fresh strength and a breath of soil and sea that are of a kind ly themselves, and must rank the unknown author among the original geniuses of his age. The passage descriptive of the superstition of invisible hunting has been quoted by Beattie in his Essay's on Potry and Music, and by Scott in his Minstrelsy of the Scottish Border.

\section{ALBANIA.}

O Loved Albania! hardy nurse of men ! Holding thy silver cross, I worship thee, On this thy old and solemn festival, Early, ere yet the wakeful cock has crowed. 
Hear! goddess, hear! that on the beryl flood, Enthroned of old, amid the waters sound, Reign'st far and wide o'er many a sea-girt spot.

Oh smile! whether on high I)unedin thou Guardest the steep and iron-bolted rock Where trusted lie the monarchy's last gems, The sceptre, sword, and crown, that graced the brows,

Since father Fergus, of an hundred kings :

Or if, along the well-contested ground, The warlike Border-land, thou marchest proud, In Teviotdale, where many a shepherd dwells, By lovely winding 'Tweed, or Cheviot brown.

Nor ween I now in Durham's lofty spire 'To seek thee, though thy loved St. David's work;

Nor where Newcastle opes her jetty mines Of coal; nor in strong Berwick; nor in Man, That never dreaded plague; nor in the wilds Of stony Westmorland: all once thy own.

Hail, land of bowmen! seed of those who scomed To stoop the neck to wide imperial Rome.

$O$ dearest half of Albion, sea-walled!

Hail! state unconquered by the fire of war, Red war, that twenty ages round thee burned! To thee, for whom my purest raptures glow, Kneeling with filial homage, I devote My life, my strength, my first and latest song. Shall I forget thy tenderness? shall I Thy bounty, thy parental cares forget, Hissing with viper's tongue?-who born of thee, Now twice twelve years have drawn thy vital air, 
And eat thy fruit, protected with thy sons; Though stronger far and holier is the tie By which are knit my heart-strings to thy love; Thou gav'st me, yet an infant unbaptised, Immortal wealth, the seeds of better life.

Thou goddess! by the softening sun beloved, Rejoicest, he with unfulfilled desire Delights not only on thy face to dwell

In amorous smile the live-long summer's day, But, looking back from the Atlantic brine, Eyes thy glad slumbers with reflected beam, And glitters o'er thy head the clear night long.

Neglect not thou the sea, that yields thee salt, Salt, origin of tastes, with which we eat The well-fed ox, and bread by labour earned.

Thence too the coal its nitrous spirit drawsCoal such as dug from firry Elphingston, Or Winton's level land that smiles with wheat, Brings back bright ore, reward of industry, Or such as in Montrose, fair harboured town, They burn; or in Alectum, lofty domed, And dims, Edina, thy aspiring brow.

No other fuel claimeth Glasgow blue, Watery Linlithgow's royal seat, or Perth, Whose evening bells the roving Highlander Hears sweet, though far descending Stenton hill, Nor Fife, well-peopled in her sea-towns tiled. Such also we in high Devana burn, Glancing on marble hearth, the oily jet Crackling full fast makes mild the bitter air 
With sulphured steam, and thaws with grateful warmth The frozen pilgrim, while the glowing grate Doubles the heat, and gay the enlivened hall laughs wide, illumined with the pleasing gleam.

Ere since of old the haughty thanes of Ross-So to the simple swain tradition tellsWere wont with clans and ready vassals thronged To wake the bounding stag or guilty wolf, There oft is heard at midnight, or at noon, Beginning faint, but rising still more loud And nearer, voice of hunters and of hounds And horns hoarse-winded, blowing far and keen. Forthwith the hubbub multiplies, the gale Labours with wilder shrieks and rifer din Of hot pursuit-the broken cry of deer Mangled by throttling dogs, the shouts of men, And hoofs thick beating on the hollow hill. Sudden the grazing heifer in the vale Starts at the noise, and both the herdsman's ears Tingle with inward dread. Aghast he eyes The mountain's height and all the ridges round;

Yet not one trace of living wight discerns, Nor knows, o'erawed and trembling as he stands,

To what or whom he owes his idle fearTo ghost, to witch, to fairy, or to fiend; But wonders, and no end of wondering finds. Albania dear, attend! behold I seek Thy angel night and day with eager feet On peopled const and western mountain lone, In city paved and well-aired village thatched, 
From end to end of Scotland many-mined. Oft too I dare the deep, though winter storms Rage fierce, and round me mad Corbrecho roar, Wafted with love to see Columba's isles.

There view I winged Skye, and Lewes long, Resort of whales; and Wyste where herrings swarm ; And talk, at once delighted and appalled, By the pale moon, with utmost Hirta's seers, Of beckoning ghosts and shadowy men that bode Sure death. Nor there doth Jura's double hill Escape my sight; nor Mull, though bald and bare; Nor Ilay, where erewhile Macdonalds reigned. Thee too, Lismore! I hail St. Moloch's shrine; Inchgall, first conquered by the brand of Scots; And, filled with awe of ancient saints and kings, I kiss, O Icolmkill! thy hallowed mould. Thus, Caledonia, many-hilled! to thee, End and beginning of my ardent song, I tune the Druid's lyre, to thee derote This lay, and love not music but for thee. 


\title{
ALEXANDER ROSS.
}

\author{
I 699-I 784 .
}

The immediate successor and indeed imitator of Allan Ramsay as the writer of a Scottish pastoral was the teacher of a remote parish school among the Grampians. Son of an Aberdeenshire farmer, Alexander Ross was born at Kincardine O'Neil, on April 13, 1699. After taking his degree at Marischal College in I7 I8, he acted for a time, like many Scottish students, as a tutor. Afterwards he became schoolmaster successively at Aboyne and Laurencekirk, settling finally at the remote Lochlea in Forfarshire. There he remained, reared a large family on scanty means, and wrote the various poetical pieces by which he is remembered. In $\mathbf{1} 766$ he carried the manuscript of his pastoral, "Helenore, or the Fortunate Shepherdess," to Aberdeen. Beattie, the author of The 1/instrel, at that time a professor there, took an interest in the rustic poet, helped his work to publication, and secured it a hearing. The piece proved successful, and brought its author no small local fame, with the, to him, not inconsiderable sum of $£ 20$. To the present day "I Ielenore" remains popular in the north, but in spite of its frequent touches of nature and the stamp of truth about its characters, its many incongruities destroy its effect as a work of art. The poem is written in the Buchan dialect, and possesses some interest on that account; but the reader is startled to find a Helenore and a Rosalind (in this case the hero's name) among the peasantry of Scotland, and still more so to come upon these high-sounding titles contracted with easy" familiarity into "Nory" and "Lindy." The pastoral, however, has not been without an influence upon the work of later poets, and Burns has acknowledged that Scota, the muse to whom Ross addresses his invocation, afforded the suggestion for his own Coila.

It is by his songs, however, that Ross is most widely known. "Wooed and married and a'," "The Rock and the wee pickle tow," "The Bridal o't," "What ails the lasses at me?" and " To the begging we will go !" are rich in typical Scots humour, 
and full of spirit, while their homely sense, and the distinct individual tang which they possess, ensure them a place in every collection.

Ross died at Lochlea at a green old age in 1784 . A life of him by his grandson, the Rev. Alexander Thomson, minister of Lentrathen, was prefixed to the fifth edition of his poems, published at Dundee in 1812 ; and to a more recent edition, published at Glasgow in 1868 , a further memoir was written by Dr. John Longmuir. The poet at his death left some eight small volumes of verse and prose which still remain unprinted.

\section{WOOED AND MARRIED AND A'**}

$\therefore$ spoiled.

Wooke and married and a',

Married and wooed and a';

The dandilly' toast of the parish

Is wooed and married and a'.

The wooers will now ride thinner, And by, when they wonted to ca';

'Tis needless to speer for the lassie

That's wooed and married and $a$ '.

* By a curious carelessness, another song with this title was substituted for this in the Brechin edition of Ross's poems. Following that mistake, Stenhouse, in his notes to Jolnnson's Mhuseum, while attributing the Brechin version to Ross, stated that the longer piece was the work of Mrs. Scott of Dunbarton. It is possible that Ross was also the author of the substituted Brechin version; it was a habit of his to write curtailments of his songs for popular purposes. For this reason the Brechin version is also appended here. But the nine-stanza copy first given is the copy of the first two editions of Ross's poems, and must necessarily be his work. Still another song with the same title and on the same theme was written by Joanna Baillie, and is included among her poetical works. 
'The girss' had na freedom of growing

2 grass.

As lang as she wasna awa',

Nor in the town ${ }^{2}$ could there be stowing

2 steading.

For wooers that wanted to ca'.

For drinking and dancing and brulyies ${ }^{3}$,

3 broils.

And boxing and shaking of fa's,

The town was for ever in tulyies 4 ;

4 guarrels.

But now the lassie's awa'.

But had they but ken'd her as I did

'Their errand it wad ha'e been sma';

She neither kent spinning nor carding,

Nor brewing nor baking ava'.

But wooers ran all mad upon her,

Because she was bonnie and braw,

And sae I dread will be seen on her,

When she's byhand and awa'.

He'll roose 5 her but sma' that has married her, 5 rate, extol.

Now when he's gotten her a',

And wish, I fear, he had miscarried her,

'Tocher and ribbons and a'.

For her art it lay all in her dressing;

But gin her braws ance were awa',

I fear she'll turn out o' the fashion,

And knit up her moggans ${ }^{6}$ with straw.

6 hose without feet.

For yesterday I yeed 7 to see her, 7 went.

And $O$ she was wondrous braw,

Yet she cried to her husband to gi'e her

An ell of red ribbons or twa. 
He up and he set doun beside her

A reel and a wheelie to ca';

She said, Was he this gate to guide her?

And out at the door and awa'.

Her neist road was hame till her mither,

Who speer'd at her now, How was a'?

She says till her, "Was't for nae ither

That I was married awa',

But gae and sit down to a wheelie,

And at it baith night and day ca',

${ }^{1}$ lad.

And ha'e the yarn reeled by a cheelie',

That ever was crying to draw!"

2 meal-dish.

Her mother says till her, "Hech, lassie,

He's wisest, I fear, of the twa;

Ye'll ha'e little to put in the bassie ${ }^{2}$,

Gin ye be backward to draw.

'Tis now ye should work like a tiger

And at it baith wallop and ca',

As lang's ye ha'e youthhead and vigour,

And little anes and debt are awa'.

3 swiftly.

4 holding.

5 neighbour.

${ }^{6}$ clipped, curtailed.
"Sae swythe 3 awa' hame to your hadding4,

Mair fool than when ye came awa';

Ye maunna now keep ilka wedding;

Nor gae sae clean-fingered and braw; But mind with a neiper ${ }^{5}$ you're yokit, And that ye your end o't maun draw, Or else ye deserve to be dockit ${ }^{6}$;

Sae that is an answer for a'." 
WOOED AND MAKKIED AND A'. 91

Young lucky now finds herself nidder'd',

- kept under.

And wist na well what gate to ea';

But with hersel' even considered

That hamewith were better to draw,

And e'en tak' her chance of her landing,

However the matter might fa';

Folk need not on frets ${ }^{2}$ to be standing

'That's wooed and married and a'. 


\section{WOOED AND MARRIED AND A'.}

3 wiped.

2 nag with white spot on face.
The bride cam' out o' the byre, And $\mathrm{O}$, as she dighted ${ }^{x}$ her cheeks, "Sirs I'm to be married the-night, And ha'e neither blankets nor sheetsHa'e neither blankets nor sheets,

Nor scarce a coverlet too; The bride that has a' thing to borrow, Has e'en right meikle ado!"
Wooed and married and a'!
Married and wooed and a'!
And was she na very weel aff
That was wooed and married and a'?

Out spake the bride's father

As he cam' in frae the pleugh,

" $\mathrm{O}$ haud your tongue, $\mathrm{my}$ dochter,

And ye'se get gear eneugh.

'The stirk stands $i$ ' the tether,

And our braw bawsint yade ${ }^{2}$

Will carry hame your corn:-

What wad ye be at, ye jade?" 
Out spake the bride's mither: "What, deil, needs a' this pride?

I hadna a plack" in my pouch That night I was a bride.

1 four pennies " Scots $=1$ English penay.

My gown was linsey-wolsey; And ne'er a sark ava;

And ye ha'e ribbons and buskin's Mae than ane or twa."

Out spake the bride's brither As he cam' in wi' the kye: "Puir Willic wad ne'er ha'e ta'en ye Had he kent ye as weel as I. For ye're baith proud and saucy, And no for a puir man's wife: Gin I canna get a better I'se ne'er tak' ane i' my life !"

Out spake the bride's sister As she cam' in frae the byre: "Oh, gin I were but married, It's a' that I desire !

But we puir folk maun live single, And do the best we can:

I dinna ken what I should want If I could get but a man!" 


\section{THE ROCK AND THE WEE PICKLE TOW.*}

There was an auld wife and a wee pickle tow,

And she wad gae try the spinning o't;

I distaff. She louted her down, and her rock ${ }^{1}$ took a low,

And that was a bad beginning o't.

2 wept.

3 scolded. She sat and she grat $^{2}$, and she flet ${ }^{3}$ and she flang, And she flew and she blew, and she wriggled and wrang,

+ become frantic. And she choked and boaked, and cried like to mang 4 , "Alas for the dreary spinning o't!

"I've wanted a sark for these eight years and ten,

And this was to be the beginning o't;

But I vow I shall want it for as lang again,

Or ever I try the spinning o't.

For never since ever they ca'd me as they ca' me,

5 disaster. Did sic a mishap or mishanter 5 befa' me;

But ye shall ha'e leave baith to hang me and draw me

The neist time I try the spinning o't.

* An abridgement of this piece for singing purposes, made probably by Ross himself, was printed in Herd's collection, and is the version usually given in the song books. 
"I ha'e keepit my house for these threescore o' years,

And aye I kept free o' the spinning o't;

But how I was sarked, foul fa' them that speers!

For it minds me upo' the beginning o't.

But our women are nowadays grown a' sae braw

That ilk ane maun ha'e her sark, and some maun ha'e twa;

The warld was better when ne'er ane ava'

Had a rag but ane at the beginning o't.

" Foul fa' her that ever advised me to spin,

'That had been sae lang a-beginning o't!

I might well have ended as I did begin,

Nor have got sic a scare wi' the spinning o't.

But they'll say. 'She's a wise wife that kens her ain weird $^{1}$;

I thought on a day it should never be speer'd,

'How loot ye the low tak' your rock by the beard

When ye gaed to try the spinning o't?'

"The spinning, the spinning, it gars my heart sob When I think upon the beginning o't;

I thought ere I died to have ance made a wob $^{2}$, = web. But still I had wears ${ }^{3}$ of the spinning o't.

But had I nine dochters, as I ha'e but three,

The safest and soundest advice I could gi'e,

Is that they frae spinning wad keep their hands free, For fear of a bad beginning o't. 
"Yet, in spite of my counsel, if they will needs run

The drearysome risk of the spinning o't, ${ }^{1}$ sheltered place. I.et them seek out a lyth ${ }^{\mathrm{I}}$ in the heat of the sun,

And there venture on the beginning o't.

But to do as I did, alas I arow !

To busk up a rock at the cheek o' the low,

Says that I had but little wit in my pow,

And as little ado wi' the spinning o't.

"But yet, after a', there is ae thing that grieves My heart to think o' the beginning o't;

Had I won the length but of ae pair o' sleeves

Then there had been word o' the spinning o't.

This I wad ha'e washen and bleached like the snaw,

2 arms.

3 stockingette sleeves.

4 jog.

5 earth.

6 unlucky.

7 hollow.

8 left way growing.

9 rowan-tree.
And on my twa gardies ${ }^{2}$ like moggans ${ }^{3}$ wad draw, And then folk wad say that auld Girzy was braw, And a' was upon her ain spinning o't.

"But gin I could shog 4 about till a new spring, I should yet ha'e a bout o' the spinning o't; A mutchkin o' lintseed I'd in the yerd's fling, For a' the wanchancy ${ }^{6}$ beginning o't. I'll gar my ain Tammy gae down to the howe? And cut me a rock o' a widdershins grow ${ }^{8}$ Of good rantry-tree 9 for to carry my tow, And a spindle o' same for the twining o't. 
"For now, when I mind me, I met Maggie Grim 'That morning, just at the beginning o't; She was never ca'd chancy, but canny and slim, And sae it has fared wi' my spinning o't. But gin my new rock were ance cutted and dry; I'll a' Maggie's cann and her cantrips' defy, And, but ony sussie ${ }^{2}$, the spinning I'll try; And ye shall a' hear o' the beginning o't."

' cunning and spells.

2 without any anxiety. 


\section{JAMES THOMSON.}

\section{I $700-1748$.}

If not singly the greatest, certainly not second to the greatest of the Scottish poets of the early part of the eighteenth century was James Thomson. Standing side by side with "The Gentle Shepherd" for freshness and charm, "The Seasons," equally with Ramsay's pastoral, sounded the note of revolt against the conventional school of Pope, and led the poetry of the country back to natural and unaffected themes.

The poet was born at Ednam in Roxburghshire, of which his father was minister, on September I I, I 700. Shortly afterwards the family removed to Southdean, and from the manse there every day during his boyhood Thomson trudged six miles down the Jed valley to school in the little country town. It was the scenery of that valley which he afterwards described in his poem of "Autumn." Close by Jedburgh an Edinburgh graduate named Riccarton had settled as a farmer. This enthusiast, who appears to have been a man of refinement and a poet, taught the boys Latin in an aisle of the parish church, and a poem of his, "A Winter's Day," is said to have sown the seed in his pupil's mind which years afterwards germinated into "The Seasons." From Jedburgh school Thomson passed to Edinburgh University, where he studied for five years with a view to entering the church. But a reproof which he received for the poetic and sensuous diction of his trial discourse turned his thoughts from that career, and, his father meantime having died," he presently made his way to London to seek his fortune. IIis friend David Mallet was at that time tutor to the sons of the Duke of Montrose, and at the instance of Lady Grizel Baillie, Thomson obtained a similar engagement in the family of Lord Binning. He soon, however, tired of the monotony of his employment, and gave it up. He was lingering in this condition, about Barnet, friendless, poor, and despondent, and grieving over the death of his mother, of which new's had just reached him, when the ilea of his poem of "Winter" occurred to him. At school and at college he had written verses, and some

"The immediate cause of the death of the poet's father was a cold caught in the process of exorcising a local ghost. 
of these had been printed in the Edinburgh Miscellany as early as 1820 . None of them, however, had attracted notice. The same fate seemed likely to befall his new composition. A publisher, Millan, gave him three guineas for the copyright; but for a month "Winter" lay on the counter unnoticed. Then one day, a clergyman of some literary connection, named Whatley, picked up the volume, perceived its merits, and forthwith rushed off to the coffce-houses with news of his discovery. It was the era of literary patronage, and Thomson had dedicated his work to $\mathrm{Sir}$ Spencer Compton. That gentleman presently expressed a desire to see the poet, and at the close of the interview presented him with a gift of twenty guineas, a sum equal perhaps to a hundred sovereigns of the present time. "The poem," says Dr. Johnson, in his "Life," "which, being of a new kind, few would venture at first to like, by degrees gained upon the public, and one edition was very speedily succeeded by another."

"Winter" was published in 1726 , a year after the appearance of Ramsay's "Gentle Shepherd." In I727 Thomson followed it up with two compositions-"Summer," and a "Poem on the Death of Sir Isaac Newton." "Spring" appeared in 1728, and "Autumn" when the poet's collected works were published in I730. In 1730 , also, his first play, "Sophonisba" appeared on the stage, though with only ordinary success. A feeble line which the play contained, "O Sophonisba, Sophonisba, O!" gave rise to a parody "O Jemmy Thomson, Jemmy Thomson O !" which for years was echoed about the streets.

Meanwhile the poet had declared himself on the side of the Opposition by the publication of "Britannia," a poetical invective, now forgotten, against the ministry of the day, whom the nation thought slow to resent the Spanish inroads. A little later he was sent to travel with the son of Sir Charles Talbot, and the knowledge of continental politics thus acquired, together with the state of party feeling at home, suggested to him the idea of a great poem on Liberty. Over this work, which was his longest, and which he looked upon as his noblest, he spent two years; but it fell still-born from the press, and has been looked on by every critic since as a dreary performance.

In 1733 , however, he received through the patronage of Sir Charles Talbot the sinecure post of Secretary of Briefs in the Court of Chancery, and for some years his naturally indolent temperament seems to have prevailed over his poetic ambition, for he published nothing. It was only in 1737 , when his patron died, and his sinecure came to an end, that he was forced again to bestir himself. He then produced his play of "Agamemnon," which was acted, but made no great mark. Pope, who, it is said, had much regard for Thomson, came to the first performance, and was received in the theatre with a round of applause. Thomson himself, watching the play from an upper gallery, was so excited that he accompanied the players with audible recitation till stopped by a friendly hint. Another play which he 
wrote forthwith, "Edward and Eleanora," failed to obtain the Lord Chamberlain's license, probably because of the author's known political opposition to the court ; and Thomson was once more reduced to indigence.

About this time Frederick, Prince of Wales, having quarrelled with his father, had set up a separate court, and in his struggle for popularity professed himself a patron of literature. Thomson was introduced to him by Mr. Lyttelton, and being gaily rallied on the state of his affairs, said that "they were in a more poetical posture than formerly," whereupon he had a pension allowed him of a hundred pounds a year. Soon afterwards he was employed, in conjunction with his friend Mallet, to write a masque, "Alfred," which was performed before the Prince at Cliefden House. And in I744, Mr. Lyttelton being in power, the poet obtained the office of Surveyor-General of the Leeward Islands, a sinecure from which, when his deputy was paid, he received about $£ 300$ a year.

A year later Thomson produced the most popular of all his plays, "Tancred and Sigismunda," which was acted at intervals down to the latter part of the century. He also wrote another drama, "Coriolanus," which was put on the stage after his death, in 1749 .

His last, and artistically his most perfect work, however, was his "Castle of Indolence," which was published in 1748, three months before he died. Written in the Spenserian stanza and manner, its two cantos picturing indolence and industry respectively, it is said to have occupied its author fifteen years in composition, and it remains one of the most perfectly finished English poems of the eighteenth century.

Catching cold on the river between Iondon and $\mathrm{Kew}$, the poet fell into a fever which ended his life on August 27th, 1748. He was buried in Richmond Church, and a monument to his memory was set up in Westminster Abbey. Rather above the middle size, and of dull, rather gross appearance, Thomson is described as silent in mingled company but cheerful among a select few, and from the stories recorded of devotion towards him he seems to have been capable of inspiring a deep and lasting affection in his friends. It says much for his goodness of heart that in the midst of his own distresses he still managed to send assistance to the sisters left behind him in the north.

Thomson's collected dramas were published in two volumes in 1768 by $A$. Donaldson, Edinburgh. Of the many editions of his poems probably the finest was that published by the Etching Club in 1842. Among more recent editions the "Aldine" is to be recommended.

Between the ages of Pope and Scott, Thomson continued the most popular poet in the English language, and it would be difficult to set a limit to the extent of his influence. His plays, cold and undramatic, were of no great moment; and his political pieces, dreary diatribes and citations, might have remained un. 
written. Even his "Castle of Indolence," with its rich archaic setting and its sensuous and languid splendour, must have exercised a charm always only upon the inner few. But his "Seasons" were a new voice on the earth; their imagrery, fresh and exuberant, carried men back to the natural wells of delightthe simple enjoyments of sense, the glory of valley and woodland, and the magic and the majesty of the sea. The verse, moreover, in which they were written was the first blank verse of the modern kind. Of the "Seasons," "Winter" was his greatest work. In it, the chief defect of which he has been accused, want of method, remains indeed as evident as elsewhere, but in it also his highest qualities are seen at their richest and best. After his death his friend Lord Lyttelton said of him that his writings contained "no line which, dying, he could wish to blot,"

\section{WINTER.}

[After an invocation to the subject, the poem opens with an address to the Earl of Wilmington, who is praised as "a firm, unshaken, uncorrupted soul, amid a sliding age." The coming of winter is then described.]

Now, when the cheerless empire of the sky To Capricorn the Centaur Archer yields, And fierce Aquarius stains th' inverted year;

Hung o'er the farthest verge of heaven, the Sun

Scarce spreads through ether the dejected day.

Faint are his gleams, and ineffectual shoot

His struggling rays, in horizontal lines

Through the thick air, as, clothed in cloudy storm, Weak, wan, and broad, he skirts the southern sky, And, soon descending, to the long dark night, Wide-shading all, the prostrate world resigns.

Nor is the night unwish'd; while vital heat, Light, life, and joy, the dubious day forsake. 
Meantime, in sable cincture, shadows vast, Deep-tinged and damp, and congregated clouds, And all the vapoury turbulence of heaven, Involve the face of things. Thus Winter falls, A heavy gloom oppressive o'er the world, Through Nature shedding influence malign, And rouses up the seeds of dark disease. The soul of Man dies in him, loathing life, And black with more than melancholy views. The cattle droop and o'er the furrowed land, Fresh from the plough, the dun discoloured flocks, Untended, spreading, crop the wholesome root.

Along the woods, along the moorish fens, Sighs the sad Genius of the coming storm: And up among the loose disjointed cliffs, And fractured mountains wild, the brawling brook, And cave, presageful, send a hollow moan, Resounding long in listening Fancy's ear.

Then comes the father of the tempest forth, Wrapt in black glooms. First joyless rains obscure Drive through the mingling skies with vapours foul; Dash on the mountain's brow, and shake the woods, That grumbling wave below. 'Th' unsightly plain Lies a brown deluge, as the low-bent clouds Pour flood on flood, yet unexhausted still Combine, and deepening into night, shut up The day's fair face. The wanderers of heaven Each to his home retire; save those that love To take their pastime in the troubled air, Or skimming flutter round the dimply pool. The cattle from th' untasted fields return, 
And ask, with meaning low, their wonted stalls,

Or ruminate in the contiguous shade.

Thither the household feathery people crowd,

The crested cock, with all his female train,

Pensive, and dripping; while the cottage-hind

Hangs o'er th' enlivening blaze, and taleful there

Recounts his simple frolic. Much he talks,

And much he laughs; nor recks the storm that blows

Without, and rattles on his humble roof.

Wide o'er the brim, with many a torrent swelled, And the mixed ruin of its banks o'erspread, At last the roused-up river pours along. Resistless, roaring, dreadful, down it comes From the rude mountain and the mossy wild, Tumbling through rocks abrupt, and sounding far; Then o'er the sanded valley floating spreads, Calm, sluggish, silent; till again, constrained Between two meeting hills, it bursts away, Where rocks and woods o'erhang the turbid stream; There, gathering triple force, rapid, and deep, It boils, and wheels and foams, and thunders through.

Nature! great parent! whose unceasing hand Rolls round the Seasons of the changeful year, How mighty, how majestic, are thy works!

With what a pleasing dread they swell the soul!

That sees astonished, and astonished sings. Ye too, ye winds! that now begin to blow With boisterous sweep, I raise my voice to you. Where are your stores, ye powerful beings! say, Where your aërial magazines reserved, To swell the brooding terrors of the storm? 
In what far distant region of the sky,

Hushed in deep silence, sleep ye when 'tis calm?

When from the pallid sky the sun descendsWith many a spot, that o'er his glaring orb Uncertain wanders, stained-red fiery streaks Begin to flush around. The reeling clouds Stagger with dizzy poise, as doubting yet Which master to obey; while rising slow, Blank, in the leaden-coloured east, the Moon Wears a wan circle round her blunted horns. Seen through the turbid fluctuating air, The stars obtuse emit a shivered ray; Or frequent seem to shoot athwart the gloom And long behind them trail the whitening blaze. Snatched in short eddies, plays the withered leaf; And on the flood the dancing feather floats. With broadened nostrils to the sky up-turned, The conscious heifer snuffs the stormy gale. Even as the matron, at her nightly task, With pensive labour draws the flaxen thread, The wasted taper and the crackling flame Foretell the blast. But chief the plumy race, The tenants of the sky, its changes speak. Retiring from the downs, where all day long They picked their scanty fare, a blackening train Of clamorous rooks thick-urge their weary flight, And seek the closing shelter of the grove. Assiduous, in his bower, the wailing ow] Plies his sad song. The cormorant on high Wheels from the deep, and screams along the lanci. Loud shrieks the soaring hern; and with wild wing, 
The circling sea-fowl cleave the flaky clouds.

Ocean, unequal pressed, with broken tide

And blind commotion heaves; while from the shore,

Eat into caverns by the restless wave,

And forest-rustling mountain, comes a voice,

That, solemn sounding, bids the world prepare.

Then issues forth the storm with sudden burst,

And hurls the whole precipitated air

1)own, in a torrent. On the passive main

Descends th' ethereal force, and with strong gust

Turns from its bottom the discoloured deep.

Through the black night that sits immense around,

Lashed into foam, the fierce conflicting brine

Seems o'er a thousand raging waves to burn.

Meantime the mountain-billows, to the clouds

In dreadful tumult swelled, surge above surge,

Burst into chaos with tremendous roar,

And anchored navies from their stations drive,

Wild as the winds across the howling waste

Of mighty waters. Now th' inflated wave

Straining they scale, and now impetuous shoot

Into the secret chambers of the deep,

The wintry Baltic thundering o'er their head.

Emerging thence again, before the breath

Of full exerted heaven they wing their course,

And dart on distant coasts; if some sharp rock,

Or shoal insidious, break not their career,

And in loose fragments fling them floating round.

[Night follows, with reflections on the vanities of life and the value of goodness. A snowstorm is then described, overwhelming 
the landscape, with the death of a man lost in the snow. Contrasted with this is the wanton city crowd. Winter in the Alps is referred to, and the descent of the wolves "cruel as death and hungry as the grave." Next follows the student's retreat.]

Now, all amid the rigours of the year, In the wild depth of Winter, while without The ceaseless winds blow ice, be my retreat Between the groaning forest and the shore Beat by the boundless multitude of waves.

A rural, sheltered, solitary scene,

Where ruddy fire and beaming tapers join,

To cheer the gloom. There studious let me sit, And hold high converse with the MIGHTY DEAD, Sages of ancient time, as gods revered, As gods beneficent, who blest mankind With arts, with arms, and humanized a world.

[The wise of classic ages are passed in review, from Socrates to Cato, with reflections to which their work and lives give rise.]

Thus in some deep retirement would I pass The winter-glooms, with friends of pliant soul, Or blithe, or solemn, as the theme inspired: With them would search, if Nature's boundless frame

Was called, late-rising from the void of night, Or sprung eternal from th' ETERNAL MindIts life, its laws, its progress, and its end. Hence larger prospects of the beauteous whole Would, gradual, open on our opening minds: And each diffusive harmony unite In full perfection, to th' astonished eye. 
Then would we try to scan the noral world, Which, though to us it seems embroiled, moves on In higher order, fitted and impelled

By Wispos's finest hand, and issuing all

In general Good. The sage historic Muse

Should next conduct us through the deeps of time;

Shew us how empires grew, declined, and fell,

In scatter'd states; what makes the nations smile,

Improves their soil, and gives them double suns;

And why they pine beneath the brightest skies,

In Nature's richest lap. As thus we talked,

Our hearts would burn within us, would inhale

That portion of divinity, that ray

Of purest heaven, which lights the public soul

Of patriots, and of heroes. But if doomed

In powerless humble fortune to repress

These ardent risings of the kindling soul;

Then, even superior to ambition, we

Would learn the private virtues; how to glide

Through shades and plains, along the smoothest stream

Of rural life: or snatched away by hope,

Through the dim spaces of futurity

With earnest eye anticipate those scenes

Of happiness and wonder, where the mind,

In endless growth and infinite ascent,

Rises from state to state, and world to world.

But when with these the serious thought is foiled,

We, shifting for relief, would play the shapes

Of frolic fancy; and incessant form

Those rapid pictures, that assembled train 
Of fleet ideas, never joined before, Whence lively Wit excites to gay surprise;

Or folly-painting Humour, grave himself, Calls laughter forth, deep-shaking every nerve.

Meantime the village rouses up the fire; While well attested, and and as well believed, Heard solemn, goes the goblin-story round; Till superstitious horror creeps o'er all. Or, frequent in the sounding hall, they wake The rural gambol. Rustic mirth goes round: The simple joke that takes the shepherd's heart, Easily pleased; the long loud laugh, sincere; The kiss, snatched hasty from the side-long maid, On purpose guardless, or pretending sleep : The leap, the slap, the haul; and, shook to notes Of native music, the respondent dance. Thus jocund fleets with them the winter night. The city swarms intense. The public haunt, Full of each theme, and warm with mixt discourse, Hums indistinct. The sons of riot flow Down the loose stream of false enchanted joy, To swift destruction. On the rankled soul The gaming fury falls; and in one gulph Of total ruin, honour, virtue, peace, Friends, families, and fortune, headlong sink. Up springs the dance along the lighted dome, Mixed, and evolved, a thousand sprightly ways. The glittering court effuses every pomp; The circle deepens: beamed from gaudy robes, Tapers, and sparkling gems, and radiant eyes, A soft effulgence o'er the palace waves: 
While, a gay insect in his summer shine, The fop, light-fluttering, spreads his mealy wings.

[An address to Chesterfield follows; then the poet returns to country scenes.]

To thy loved haunt return, my happy Muse: For now, behold, the joyous winter days, Frosty, succeed; and through the blue serene, For sight too fine, the ethereal nitre flies, Killing infectious damps, and the spent air Storing afresh with elemental life.

Close crowds the shining atmosphere; and binds Our strengthen'd bodies in its cold embrace, Constringent; feeds, and animates our blood; Refines our spirits through the new-strung nerves, In swifter sallies darting to the brain; Where sits the soul, intense, collected, cool, Bright as the skies, and as the season keen.

All Nature feels the renovating force Of Winter, only to the thoughtless eye In ruin seen. The frost-concocted glebe Draws in abundant vegetable soul, And gathers vigour for the coming year. A stronger glow sits on the lively cheek Of ruddy fire; and luculent along The purer rivers flow; their sullen deeps, Transparent, open to the shepherd's gaze, And murmur hoarser at the fixing frost,

What art thou, Frost? and whence are thy keen stores

Derived, thou secret all-invading power 
Whom even th' illusive fluid cannot fly?

Is not thy potent energy, unseen,

Myriads of little salts, or hooked, or shaped

Like double wedges, and diffused immense

Through water, earth, and ether? Hence at eve,

Steamed eager from the red horizon round,

With the fierce rage of Winter deep suffused,

An icy gale, oft shifting, o'er the pool

Breathes a blue film, and in its mid career

Arrests the bickering stream. The loosened ice,

Let down the flood, and half dissolved by day,

Rustles no more; but to the sedgy bank

Fast grows, or gathers round the pointed stone,

A crystal pavement, by the breath of heaven

Cemented firm; till, seized from shore to shore,

The whole imprisoned river growls below.

Loud rings the frozen earth, and hard reflects

A double noise; while, at his evening watch,

The village-dog deters the nightly thief.

The heifer lows; the distant waterfall

Swells in the breeze; and with the hasty tread

Of traveller, the hollow-sounding plain

Shakes from afar. The full ethereal round,

Infinite worlds disclosing to the view,

Shines out intensely keen; and, all one cope

Of starry glitter, grows from pole to pole.

[The effects of the frost are described, with a skating scene on the canals of Holland, and hunting in the Siberian desert. Still farther north, the polar nations are seen, "guiding their daring steps to Finland fairs"; and at last, amid ice and tempest, the palace of Winter himself is reached. As the type of the 
north, Peter the Great is alluded to, and the civilizing effects of his government. Next follow the dangers of Arctic exploration; and the poem ends with reflections drawn from the revolution of the seasons.]

'Tis done! dread Winter spreads his latest glooms, And reigns tremendous o'er the conquered year. How dead the vegetable kingdom lies!

How dumb the tuneful! Horror wide extends His desolate domain. Behold, fond Man!

See here thy pictured life; pass some few years, Thy flowering Spring, thy Summer's ardent strength, Thy sober Autumn fading into age, And pale concluding Winter comes at last, And shuts the scene. Ah! whither now are fled Those dreams of greatness? those unsolid hopes Of happiness? those longings after fame? Those restless cares? those busy bustling days? Those gay-spent, festive nights? those veering thoughts Lost between good and ill, that shared thy life? All now are vanished! VIRTUE sole survives

Immortal never-failing friend of Man, His guide to happiness on high. And see! 'Tis come, the glorious morn! the second birth Of heaven and earth! awakening Nature hears The new-creating word, and starts to life In every heightened form, from pain and death For ever free. The great eternal scheme, Involving all, and in a perfect whole Uniting, as the prospect wider spreads, To Reason's eye refined clears up apace. Ye vainly wise! ye blind presumptuous! now, 
Confounded in the dust, adore that Power, And Wisdom oft arraigned: see now the cause, Why unassuming worth in secret lived, And died neglected; why the good Man's share In life was gall and bitterness of soul; Why the lone widow and her orphans pined In starving solitude, while Luxury, In palaces, lay straining her low thought To form unreal wants why; heaven-born truth And moderation fair wore the red marks Of superstition's scourge; why licensed pain, That cruel spoiler, that embosomed foe, Imbittered all our bliss. Ye good distrest ! Ye noble few! who here unbending stand Beneath life's pressure, yet bear up a while, And what your bounded view, which only saw A little part, deemed Evil, is no more. The storms of wintry Time will quickly pass, And one unbounded Spring encircle all. 


\section{THE CASTlE OF INDOLENCE.}

OPENING DESCRIPTION.

O MORTAL man! who livest here by toil,

Do not complain of this thy hard estate;

That like an emmet thou must ever moil,

Is a sad sentence of an ancient date;

And, certes, there is for it reason great;

For, though sometimes it makes thee weep and wail,

And curse thy star, and early drudge and late,

Withouten that would come an heavier bale, Loose life, unruly passions, and diseases pale.

In lowly dale, fast by a river's side,

With woody hill o'er hill encompassed round,

A most enchanting Wizard did abide,

Than whom a fiend more fell is nowhere found.

It was, I ween, a lovely spot of ground;

And there a season atween June and May,

Half prankt with spring, with summer half imbrowned,

A listless climate made, where, sooth to say, No living wight could work, ne cared even for play, 
Was nought around but images of rest:

Sleep-soothing groves, and quiet lands between ; And flowery beds, that slumbrous influence kest,

From poppies breathed; and beds of pleasant green

Where never yet was creeping creature seen.

Meantime unnumbered glittering streamlets played,

And hurled everywhere their waters sheen;

That as they bickered through the sunny glade, Though restless still themselves, a lulling nurmur made.

Joined to the prattle of the purling rills,

Were heard the lowing herds along the vale, And flocks loud-bleating from the distant hills,

And vacant shepherds piping in the dale:

And now and then sweet Philomel would wail,

Or stock-doves plain amid the forest deep,

That drowsy rustled to the sighing gale;

And still a coil the grasshopper did keep :

Yet all these sounds yblent inclined all to sleep.

Full in the passage of the vale, above,

A sable, silent, solenın forest stood;

Where nought but shadowy forms was seen to move,

As idless fancied in her dreaming mood:

And up the hills, on either side, a wood

Of blackening pines, aye waving to and fro,

Sent forth a sleepy horror through the blood;

And where this valley winded out, below,

The murmuring main was heard, and scarcely heard, to flow. 
A pleasing land of drowsy-hed it was, Of dreams that wave before the half-shut eyc, And of gay castles in the clouds that pass For ever flushing round a summer sky; There eke the soft delights, that witchingly Instil a wanton sweetness through the breast, And the calm pleasures, always hovered nigh. But whate'er smacked of noyance, or unrest, Was far far off expelled from this delicious nest.

The landscape such, inspiring perfect ease,

Where INDOLENCE (for so the Wizard hight ${ }^{t}$ ) ' ' is named.

Close-hid his castle 'mid embowering trees,

That half shut out the beams of Phoebus bright

And made a kind of chequered day and night.

Meanwhile, unceasing at the massy gate,

Beneath a spacious palm, the wicked wight Was placed; and, to his lute, of cruel fate And labour harsh complained, lamenting man's estate. 


\title{
DAVID MALLET.
}

\author{
$1700-1765$.
}

When the name MacGregor was proscribed in Scotland one of the members of the clan changed his patronymic to that of Malloch. A descendant, possibly a son, of this person, was the poet afterwards known as David Mallet. His parents were in lowly circumstances, and he is said to have acted for a time as janitor of Edinburgh High Sichool. Presently, however, on the recommendation of the University authorities, he became tutor to the sons of the Duke of Montrose, with whom he travelled, and through whom he found an introduction to the greater society of London of his day. So adroitly did he avail himself of his opportunities that he became Under-Secretary to Frederick, Prince of Wales, at a salary of $£ 200$ a year. Something of his pliability. and astuteness may be gathered from his change of name. Finding that the coffee-house wits were apt to nickname him Moloch, he changed his Scottish surname to an English shape, and turned Malloch into Mallet.

Of the poet's personal character perhaps the less said the better. Dr. Johnson has recorded that " he was the only Scot whom Scotchmen did not commend," and Professor Walker more recently has summed his vices in a sentence-." He was a venal writer, a treacherous friend, a dishonest man." * After the death of Pope, who had been his friend, he accepted a reward from Bolingbroke to blacken the memory of the poet. He took, under the will of the Duchess of Marlborough, a bequest of $£ 1000$ to write a life of the Duke, to which he never put his pen. And he accepted the job of stirring popular feeling against the unfortunate Admiral Byng, for whose destruction he wrote and published a letter under the signature of "A I'lain Man." For some of his other dishonourable meannesses the reader may be referred to Johnson's "Lives of the Poets." The quondam tutor, however, made some figure in the London life of his time. When Gibbon, the future historian, announced at Oxford that he had embraced Catholicism, it was to Mallet's 
house that his father took him in the hope of weaning him from that faith. And it was to Mallet that the brilliant and un. scrupulous Bolingloroke bequeathed the atheistic part of his writings, which the poet published in 1754 .

Mallet was twice married. By his first wife he had seven children, and one of his daughters was the authoress of at tragedy performed at Drury Lane. Two years before his death he was appointed Keeper of the Book of Entries for ships in the port of London.

Mallet's finest and best-known poem, the ballad of "William and Margaret," was founded on an actual incident, the seduction of a daughter of I'rofessor James Gregory of St. Andrews by at son of Sir William Sharpe of Strathyrum, and a nephew of the notorious Archbishop Sharpe. On discovery of his daughter's misfortune Dr. Gregory, it is said, made Mr. Sharpe the offer of half his fortune if he would marry the young lady. The offer was rejected with scorn, and presently, sinking under grief and shame, Miss Giregory died. Shortly after the occurrence the composition of the lallad was suggested to Mallet by a verse in Fletcher's comedy, "The Knight of the Burning Pestle." The piece was pulblished in the Orpheus Caledonius in 1725.

Another ballad, "Edwin and Enma," which the poet based likewise upon actual circumstance, is tainted with the worst faults of the artificial school. The same thing is to be said of his piece on "Verbal Criticism," which was written to pay court to lope. And the "Excursion," which he published in 1728, in emulation of Thomson's "Seasons," contains all the faults and none of the merits of his early friend's work. A pastoral, "Amyntor and Theodora," published in 1747, for which he received the sum of $£ 120$, displays somewhat more vigour and spirit, but at its best it also only echoes the blank verse of Thomson. Mallet also produced one or two short pieces in light strain, somewhat in the vein of modern zers de societé. He was author, as well, of poetical epistles, prologues and epilogues to the dramas of friends, \&c. Besides his poetry he wrote, in $175^{\circ}$, the life of Bacon, still prefixed to that philosopher's works. Some of his pieces had also considerable success on the stage-"Eurydice," in I73I, "Mustapha," satirizing Walpole in order to please Prince Frederick, in 1739, and "Elvira," in 1763 . He was also joint author with Thomson of the masque of "Alfred"; and this and his other masque, "Britannia," both contain lyrics which are remembered. Mallet's poems were included in the series of poets edited by Dr. Johnson. They have been re-printed in Chalmers's Collection in 1810 , and in the Chiswick I'oets in $1 \$ 22$. 


\section{WILLIAM AND MARGARET.}

"Iwas at the silent, solemn hour, When night and morning meet; In glided Margaret's grimly ghost, And stood at William's feet.

Her face was like an April morn

Clad in a wintry cloud;

And clay-cold was her lily hand,

'That held her sable shroud.

So shall the fairest face appear,

When youth and years are flown:

Such is the robe that kings must wear

When death has reft their crown.

Her bloom was like the springing flower

That sips the silver dew;

The rose was budded in her cheek, Just opening to the view.

But love had, like the canker-worm, Consumed her early prime:

'The rose grew pale, and left her cheekShe died before her time. 
"Awake!" she cried, "thy true-love callsCome from her midnight grave:

Now let thy pity hear the maid

Thy love refused to save.

"This is the dumb and dreary hour When injured ghosts complain;When yawning graves give up their dead 'Io haunt the faithless swain.

"Bethink thee, William, of thy fault, Thy pledge and broken oath ! And give me back my maiden vow, And give me back my troth.

"Why did you promise love to me, And not that promise keep? Why did you swear my eyes were bright, Yet leave those eyes to weep?

"How could you say my face was fair, And yet that face forsake?

How could you win my virgin heart, Yet leave that heart to break?

"Why did you say my lip was sweet, And made the scarlet pale? And why did I, young witless maid! Believe the flattering tale? 
"That face, alas! no more is fair, Those lips no longer red:

Dark are my eyes, now closed in death, And every charm is fled.

"The hungry worm my sister is; This winding-sheet I wear: And cold and weary lasts our night, Till that last morn appear.

"But hark! the cock has warned me hence. A long and last adieu!

Come, see, false man, how low she lies, Who died for love of you."

The lark sang loud, the morning smiled IVith beams of rosy red;

Pale William quaked in every limb, And raving left his bed.

He hied him to the fatal place

Where Margaret's body lay ;

And stretched him on the green grass turf That wrapt her breathless clay.

And thrice he called on Margaret's name, And thrice he wept full sore; 'Then laid his cheek to her cold grave, And word spake nevermore. 


\section{RULE BRITANNIA.}

(From Masque of Alfred, Act ii. Scene 5.)

WukN Britain first, at heaven's command,

Arose from out the azure main,

This was the charter of the land,

And guardian angels sang this strain.

"Rule, Britannia, rule the waves:

Britons never will be slaves."

'The nations not so blest as thee

Must in their turus to tyrants fall;

While thou shalt flourish great and free,

The dread and envy of them all.

Rule, Britannia, rule the waves:

Britons never will be slaves.

Still more majestic shalt thou rise,

More dreadful from each foreign stroke:

As the loud blast that tears the skies

Serves but to root thy native oak.

Rule, Britannia, rule the waves:

Britons never will be slaves. 
Thee haughty tyrants ne'er shall tame: All their attempts to bend thee down IVill but arouse thy generous flame-

But work their woe and thy renown. Rule, Britannia, rule the waves: Britons never will be slaves.

To thee belongs the rural reign;

Thy cities shall with commerce shine;

All thine shall be the subject main, And every shore it circles thine.

Rule, Britannia, rule the waves:

Britons never will be slaves.

The Muses, still with freedom found, Shall to thy happy coast repair.

Blest isle! with matchless beauty crowned, And manly hearts to guard the fair.

Rule Britannia, rule the waves:

Britons never will be slaves.*

*In the edition of "Alfred" of I75I, three stanzas lyy Lord Bolingloroke were substituted for the three final stanzas of this song as printed in the original editions in 1740 . The song is here given in its original form. 


\section{THE BIRKS OF INVERMAY.}

'THE smiling morn, the breathing spring,

Invite the tuneful birds to sing;

And while they warble from each spray,

Love melts the universal lay.

Let us, Amanda, timely wise,

Iike them improve the hour that flies;

And in soft raptures waste the day

Among the shades of Invermay.

For soon the winter of the year, And age, life's winter, will appear;

At this thy living bloom will fade,

As that will strip the vernal shade.

Our taste of pleasure then is o'er;

The feathered songsters love no more;

And when they droop and we decay,

Adieu the shades of Invermay!*

* Invermay is a small woody glen descending to the Ewrie, about nine miles from Perth. To Nallet's two stanzas above other three were added by the Rev. Alexander Bryce of Kirk. newton (1713-1786). 


\section{WILLIAM HAMILTON OF B A NGOUR.-I704-1 754 .}

William Hamilton of Bangour is invariably so called in order to distinguish him from that other William Hamilton of his time, of Gilbertfield, who was also a poet. The second son of a gentlemen of large fortune, of the estate of Bangour in Ayrshire, he early attained a reputation as one of the most courtly wits of Edinburgh, was much sought after by the fashionable society of the Scottish capital, and is referred to in contemporary correspondence as "the elegant and amiable Hamilton." At the age of twenty he was one of the ingenious young gentleman whom Ramsay acknowledged as contributors to his Tea-Table Miscellany; and he continued to write verse in the affected artificial vein then in vogue in England. A story is told of him which illustrates well the insincerity of the note of passion which it was fashionable for the poets of the day to affect in their verse. A young lady to whom IIamilton had addressed several amatory effusions complained to Home, who was a mutual friend, of the annoyance which these insincere attentions caused her, and begged his interference. Hone refused, but with a smile suggested a better plan. "Go you," he said, "to the Assembly to-night, dance with Mr. Hamilton, and show him every mark of attention, as if you took his suit in earnest and were resolved to favour it, and I warrant you shall be troubled no more with these pretences." The young ladly did as she was told, and treated Hamilton's attentions as if she took them to be sincere; whereupon the gallant, in alarm, at once cooled his ardours and assumed an air as distant as it was respectful. The poet, however, was twice married, and by his first wife, a daughter of Sir James Hall of Dunglas, he became the father of an only son.

Upon the outbreak of the Relellion in 1745 Hamilton joined the Jacobite standard, and his enthusiasm after the victory of Prestonpans found expression in an ode, which established him as the laureate of the cause. He escaped from the overthrow at Culloden with a severe contusion of the head, and in company with John Roy Stewart underwent in hicling some romantic 
adventures. The two were concealed first by the lady of the minister of Alvey, and they afterwards lay in a cave under a tree root in Gilenmore. Finally, after some hairbreadth escapes, they found a means of fleeing to France. Ilamilton spent part of his exile in Italy, but in 1749 the interest of friends procured his pardon, and he returned home. In the same year, by the death of his elder brother, he inherited the family estates in Ayrshire. But he did not live long to enjoy these. The hard. ships which he had undergone had undernined his heilth, his constitution gave way, and though he again went abroad, he died of consumption at lyons on March 25, 1754. His body was brought home and luried in the Abbey Church at Ilolyrood.

A collection of IIamilton's verses-" Poems on Several Occasions"-was printed without the author's knowledgre by the Foulises at Glasgow in 1748 , the preface to the edition being written by the celelrated Adam Smith. In 1760 the volume was reprinted with the author's corrections, at Edin. burgh. IIamilton's compositions are also included in Chalmers's ponderous collection, in the Chiswick I'ress series, and in an edition of the works of Allan Ramsay and his contemporaries edited by Charles Mackay. But the most complete edition is that edited by James Paterson at Edinburgh in 1850.

Hamilton's poems include a considerable number of imitations and translations of such classics as Homer, Virgil, and Horace, more or less happily turned, a number also of odes, songs, and society verse in the tone of his time. Besides these fashionalble productions, he essayed the mock.heroic in a piece "The Maid of Gallowshiels," but owing to his lack of humour the effort falls flat. His single title to remembrance lies in his beautiful ballad com. position, "The Braes of Yarrow," published in the Orpheus Caledonius when he was no more than twenty-one. The poem forms a kind of sequel to the old Border ballad of "The Dowie Dens o' Yarrow." Its first verse is ancient. A song by Allan Ramsay, beginning with the same verse, appears in Johnson's Musical Museum. But Hamilton's ballad far outstrips the composition of his contemporary. It stands out, one of the few genuine inheritors of the spirit of ancient folksong. Sir George Douglas has recalled the fact that "with its yearning pathos, its fresh touches of nature, its tragic passion, and its haunting tune, it has the distinction of having served as a source of inspiration to Wordsworth." * And Professor Veitch has said of it, "It breathes the soul of the place, and is so permeated by the spirit of its history and traditions, that when all the other writings of the author shall have fallen into oblivion there will still be a nook in menory and a place in men's hearts for "The Braes of Yarrow." "†

\footnotetext{
* "Scottish Minor Poets."

t "History and Poetry of the Scottish Border."
} 


\section{SONG.}

A11: the poor shepherd's mournful fate,

When doomed to love and doomed to languish, 'To bear the scornful fair one's hate,

Nor dare disclose his anguish!

Yet eager looks and dying sighs

My secret soul discover;

While rapture, trembling through mine eyes,

Reveals how much I love her.

The tender glance, the redd'ning cheek,

O'erspread with rising blushes-

A thousand various ways they speak

A thousand various wishes.

For, oh: that form, so heavenly fair,

Those languid eyes so sweetly smiling,

That artless blush and modest air,

So fatally beguiling:

Thy every look and every grace

So charm whene'er I view thee;

Till death o'ertake me in the chase,

Still will my hopes pursue thee.

Then, when my tedious hours are past.

Be this last blessing given-

I.ow at thy feet to breathe my last,

And die in sight of heaven! 


\section{THE BRAES OF YARROW.}

"BUsk" VE, busk ye, my bonnie, bonnie bride! 'Deck, prepare. Busk ye, busk ye, my winsome marrow ${ }^{2}$ ! 2 match, mate. Busk ye, busk ye, my bonnie, bonnie bride, And think nae mair on the braes of Yarrow!"

- "Where got ye that bonnie, bonnie bride? Where got ye that winsome marrow?" "I got her where I durst not well be seenPu'ing the birks on the braes of Yarrow."

"Weep not, weep not, my bonnie, bonnie bride! Veep not, weep not, my winsome marrow :

Nor let thy heart lament to leave

Pu'ing the birks on the braes of Yarrow."

"Why does she weep, thy bonnie, bonnie bride? Why does she weep, thy winsome marrow? And why dare ye nae mair weel be seen Pu'ing the birks on the braes of Yarrow?" 
"Lang maun she weep, lang maun she, maun she weep,

Lang maun she weep with dule and sorrow; And lang maun I nae mair weel be seen Pu'ing the birks on the braes of Yarrow.

"For she has tint her lover, lover dearHer lover dear, the cause of sorrow; And I have slain the comeliest swain

That e'er pu'ed birks on the braes of Yarrow.

"Why runs thy stream O Yarrow, Yarrow, reid? Why on thy braes is heard the voice of sorrow? And why yon melancholious weeds

Hung on the bonnie birks of Yarrow.

"What's yonder floats on the rueful, rueful flood? What's yonder floats? O dule and sorrow !

'Tis he, the comely swain I slew

Upon the duleful braes of Yarrow.

"IVash, O wash his wounds, his wounds in tears, His wounds in tears of dule and sorrow; And wrap his limbs in mourning weeds, And lay him on the braes of Yarrow.

"Then build, then build, ye sisters, sisters sad, Ye sisters sad, his tomb with sorrow : And weep around, in woeful wise, His hapless fate on the braes of Yarrow. 
"Curse ye, curse ye, his useless, usetess shicld, My arm that wrought the deed of sorrow, The fatal spear that pierced his breastHis comely breast on the braes of Yarrow!

"Did I not warn thee not to, not to love, And warn from fight? But, to my sorrow, Too rashly bold, a stronger arm

Thou met'st, and fell on the braes of Yarrow."

"Sweet smells the birk, green grows, green grows the grass,

Yellow on Yarrow's braes the gowan;

Fair hangs the apple frae the rock,

Sweet the wave of Yarrow flowing!"

"lilows Yarrow sweet? As sweet, as sweet flows Tweed ;

As green its grass, its gowan as yellow;

As sweet smelts on its braes the birk,

The apple from its rocks as mellow.

"Fair was thy love, fair, fair indeed thy love;

In flowery bands thou didst him fetter:

Though he was fair, and well beloved again

Than me, he never loved thee better.

"Busk ye then, busk, my bonnie, bonnie bride!

Busk ye, busk ye, my winsome marrow:

Busk ye, and lo'e me on the banks of Tweed, And think nae mair on the braes of Yarrow!" K 
"How can I busk, a bonnie, bonnie bride?

How can I busk, a winsome marrow?

How lo'e him on the banks of Tweed

That slew my love on the braes of Yarrow:

"O Yarrow fields, may never, never rain

Nor dew thy tender blossoms cover:

For there was basely slain my love-

My love as he had not been a lover.

"The boy put on his robes, his robes of green,

His purple vest-'twas my ain sewing:

Ah, wretched me! I little, little knew

He was in these to meet his ruin:

"The boy took out his milk-white, milk-white steed,

Unheedful of my dule and sorrow;

But ere the to-fall of the night

He lay a corpse on the braes of Yarrow.

"Much I rejoiced, that woeful, woeful day:

I sang, my voice the woods returning:

But lang ere night the spear was flown

That slew my love and left me mourning.

"What can my barbarous, harbarous father do,

But with his cruel rage pursue me?

My lovers blood is on thy spear;

How canst thou, barbarous man, then woo me? 
"My happy sisters may be, may be proud--With cruel and ungentle scoffin' May bid me seek, on Yarrow's braes, My lover nailed in his coffin.

"My brother Douglas may upbraid, And strive with threat'ning words to move me: My lover's blood is on thy spear, How eanst thou ever bid me love thee?

"Yes, yes, prepare the bed, the bed of love! Witl bridal sheets my body cover: Unbar, ye bridal maids, the door ; let in the expected husband lover!

"But who the expected husband, husband is? His hands, methinks, are bathed in slaughter. Ah me: what ghastly spectre's yon, Comes in his pale shroud bleeding after?

"Pale as he is, here lay him, lay him down; $\mathrm{O}$ lay his cold head on my pillow: Take aff, take aff these bridal weeds, And crown my careful head with willow.

"Pale though thou art, yet best, yet best belored:

Oh! could my warmth to life restore thet, Yèd lie all night between my breasts!

No youth lay ever there before thee. 
"Pale, pale indeed! O lovely, lovely youth!

Forgive, forgive so foul a slaughter; And lie all night between my breasts ! No youth shall ever lie there after."

" Return, return, O mournful, mournful bride! Return, and dry thy useless sorrow! Thy lover heeds nought of thy sighsHe lies a corpse on the braes of Yarrow." 


\section{ALEXANDER WEBSTER.}

$$
1707-1784 \text {. }
$$

One of the ministers of Edinburgh, where he was born and where he ctied, Dr. Webster has left two songs to the tune of Alloa House, of which much the finer is that here given. According to a tradition preserved by Chambers, this song was written in early life " in consequence of a lady of superior rank, whom Welster was engaged to woo for another, condescending to hetray a passion for him." The lady was a daughter of Colonel Erskine of Alloa, a near relation of the Dundonald family, and it is satisfactory to know that she eventually married the man of her choice, who could sing her charms in such fervent fashion.

\section{O, HOW COULD I VENTURE.}

$\mathrm{OH}$, how could I venture to love one like thee, And you not despise a poor conquest like meOn lords, thy admirers, could look wi' disdain, And knew I was naething, yet pitied my pain?

You said, while they teased you with nonsense and dress,

"When real the passion the vanity's less."

You saw through that silence which others despisc, And, while beaux were a-talking, read love in my ejes. 
Oh, how shall I fauld thee, and kiss a' thy charms, 'Till, fainting wi' pleasure, I die in your arms'Through all the wild transports of ecstasy tost, 'lill, sinking together, together we're lost !

Oh, where is the maid that like thee ne'er can cloy, Whose wit can enliven each dull pause of joy, Ind, when the short raptures are all at an end, From beautiful mistress turn sensible friend?

In vain do I praise thee, or strive to reveal, Too nice for expression, what only we feel, In $a$ ' that ye do, in each look and each mien, 'The graces in waiting adorn you unseen.

When I see you I love you; when hearing, adore;

I wonder, and think you a woman no more:

'Till, mad wi' admiring, I canna contain, And, kissing your lips, you turn woman again.

Wi' thee in my bosom how can I despair?

I'll gaze on thy beauties, and look awa' care: I'll ask thy advice when with troubles opprest, Which never displeases, but always is best.

In all that I write I'll thy judgment require; Thy wit shall correct what thy charms did inspire: I'll kiss thee and press thee till youth is all o'er, And then live in friendship, when passion's no more. 


\section{GEORGE HALKE'T.}

$-175^{6}$.

The author of the fine peasant song "Logie o' Buchan" became, in 1714 , schoolmaster at Rathen, in Aberdeenshire. llere he lived in the room in which he taught, and when he married, the back of the bed mate the only division of the house. An enthusiastic Jacobite, he wrote several pieces on the side of the Stuarts, of which the most conspicuous was "Whirry, Whigs, awa', man," or at least a rersion of it, for Hogg in his Jacolite' Relics declares the piece to be of different periods and by different hancls. Just before the battle of Culloden, Ilalket wrote is satirical dialogrue between George 11. and the Devil, and on its falling into the hands of the Duke of Cumberland a reward of f100 was offered for the person of the author, alive or dead. In 1725 llalket was expelled by the kirk session for gross misconduct. Ife then removed to Cairnbulg, where he had a full school for a cuarter of a century. Ile afterwards became tutor to the families of Colonel Fraser and Sir James Innes. In 1727 llalket published, at Aberdeen, a small volume of verse, entitlerl "Occasional Poems upon Several Suljects." Nothing in this, however, rises to the level of "Logie o' Buchan."

Logie, in the parish of Crimond, was the locality of the wellknown song, and the hero of the piece was one James Robertson, gardener at Logie Ilouse. The incident was probably an episode of the warlike levies of the Rebellion. Logie o' Buchan has been attributed, but without proof, to Lady Anne Iindsay, authoress of "Auld Robin (iray." Peter Buchan, who in his Gleanings was first to print the song, states that he follows universal tradition in assigning it to llalket. "Whirry, Whigs awa" is printed, with an account of Halket's life, in Walker's Bards of Bon-Aicord.

\section{LOGIE O' BUCHAN.}

O logie o' Buchan, O Logie the laird,

'They ha'e ta'en awa' Jamie, that delved in the yaird, Wha played on the pipe and the viol sae sma', 'They ha'e ta'en awa' Jamie, the flower o' them a': 
" Weary not. He said, "Think na lang", lassie, though I gang awa":"

He said, "Think na lang, lassie, though I gang awa'! For simmer is coming, cauld winter's awa', And I'll come and see thee in spite o' them a'!"

Though Sandy has ousen, has gear, and has kye,

*holding. A house and a hadden ${ }^{2}$, and siller forbye;

Yet I'd tak' mine ain lad, wi' his staff in his hand, Before I'd ha'e him, wi' the houses and land.

My daddy looks sulky, my ninnie 3 looks sour;

They frown upon Jamie because he is poor:

Though I lo'e them as weel as a dochter should do, 'They're nae hauf sae dear to me, Jamie, as you.

I sit on my creepie, I spin at my wheel, And think on the laddie that lo'ed me sae weel:

He had but ae sixpence, he brak' it in twa, And gi'ed me the hauf o't when he gaed awa'.

Then haste ye back, Jamie, and bide na awa': Then haste ye back, Jamie, and bide na awa': The simmer is coming, cauld winter's awa', And ye'll come and see me in spite o' them a'. 


\section{AISSON RUTHERFORI).}

\section{7 I 2-I 794 .}

One of the most interesting figures in Wiinburgh society in the middle of the eighteenth century was Mrs. Cockburn of ()rmiston. Her huband, Patrick Cockburn, who was an advocate, and son of Adam Cockburn of Ormiston, Lord Justice-Clerk, died in 1753, but throughout the forty years of her widowhood, by her wit and manners she maintained a rank: among the élite of the Scottish metropolis similar to the place which Frenchwomen occupy in the society of P'aris. She had a great talent for conversation; her entertainments were as gaty and witty as they were simple and uncostly; and within her little parlour used to gather some of the most notable men of the day, such as Lord Monboddo, I avid IIume, and John Home. "In person and features she resembled Queen Elizabeth: lut the nose was rather more aquiline. She was prond of her auburn hair, which remained unbleached by time even when she was upwards of eighty years old." Like some of the Frenchwomen whom in character she resembled, she could with great readiness upon occasion set flying both squil and parody. Mlany of these, of her composition, went the round of Edinburgh society in their time, and one of them at least is preserved for us. While she was still in the summer of her charms the father of Sir Walter Scott was a young man, and eight lines by her which were given as one of a set of toasts among a few friend. are siid to have depicted him so vividly that "the original was recognised so soon as they were read aloud"-

\footnotetext{
To a thing that's uncommon-

A youth of discretion,

Who, though vastly handsome,

Despises flirtation :

To the friend in aftiction,

The heart of affection,

Who may hear the last trumI

Without dread of detection.
}

Mrs. Cochluurn was a relative of Sir Walter's mother, who like. herself had been born a Rutherford, and when the poet himself was beginning to write verse she addressed some kindly stanzato him which are here given. Her most famous performance, 
however, is the well-known song "The Flowers of the Forest." This was written while she was still a young lady in the housc of her father, Robert Rutherford of Fernalie, in the county of Selkirk. When it first appeared, about 1765 , it was thought to be an old song and to refer to the fall of the "Seventy of Selkirk" on Flodden Field. Burns, however, judged aright. "The manners indeed are old," he wrote, "but the language is of yesterday. Its author must very soon be discovered." The authorship was made clear by Scott, who from personal recollection furnished details regarding the song and its writer for Robert Chambers' collection of 'scottish songs in 1829 . It that time, Scott says, a turret was still pointed out in the old house of Fernalie as the place where Miss Kutherford wrote the piece. The occasion, he adcled, was "a calamitous period in Ettrick Forest, when no fewer than seven lairds or proprietors, of ancient family and inheritance, having engaged in some imprudent speculations, lecame insolvent in one year."

\section{LINES TO MR. WALTER SCOTY}

On reading his poem of Guiscard and Matilda, inscribit to Miss Kith of R'acelston.

IF such the accents of thy early youth,

When playful fancy holds the place of truth;

If so divinely sweet thy numbers flow,

And thy young heart melts with such tender woe;

What praise, what admiration shall be thine,

When sense mature with science shall combine

'lo raise thy genius and thy taste refine:

Go on, dear youth, the glorious path pursue

Which bounteous nature kindly smooths for you;

(io, bid the seeds her hand hath sown arise,

By timely culture, to their native skies;

(io, and employ the poet's heavenly art, 
Not merely to delight, but mend the heart. 'Than other poets happier may'st thou prove, More blest in friendship, fortunate in love, Whilst fame, who longs to make true merit known, Impatient waits to claim thee as her own.

Scorning the yoke of prejudice and pride, Thy tender mind let truth and reason guide;

I.et meek humility thy steps attend, . Ind firm integrity, youth's surest friend.

so peace and honour all thy hours shall bless, And conscious rectitude each joy increase;

A nobler meed be thine than empty praiseHeaven shall approve thy life, and Keith thy lays. 


\section{THE}

\section{FLOIVERS OF THE FOREST.}

I've seen the smiling of fortune beguiling, I've felt all its favours and found its decay:

Sweet was its blessing,

Kind its caressing,

But now 'tis fled, 'tis fled far away.

I've seen the forest adorned the foremost,

With flowers of the fairest, most pleasant and gay;

Sae bonnie was their blooming,

Their scent the air perfuming;

But now they are withered, and are a' wede away.

I've seen the morning with gold the hills adorning, And the dread tempest roaring before parting day;

I've seen Tweed's silver streams,

Glitt'ring in the sunny beams,

Grow drumlie and dark as they rolled on their way.

O fickle fortune! why this cruel sporting?

$\mathrm{O}$ why thus perplex us, poor sons of a day?

Thy frowns cannot fear me,

Thy smiles camnot cheer me,

for the Flowers of the liorest are withered away. 


\section{JOHN WILSON.}

I $720-1789$.

Voungest son of a sma!l farmer on the estate of Corehouse, in the parish of I,esmahagow, the author of "Clyde" began the hattle of life at the early age of 14 . In 1746 he obtained the permanent situation of schoolmaster in his native parish, and five years later he married. His culture and humour appear to have made him very acceptable to the society of his neighbour. houd ; and on the publication of his first poetical essay, a sketch afterwards enlarged into his tragedy of "Earl Douglas," he was invited to an interview with the Duke of Douglas. The story of that interview, told by Leyden, forms one of the two outstanding incidents in Wilson's life. The Duke, it appears, desired the poet to sit down and drink wine with him. At the second glass his Grace suddenly leapt to his feet, produced a pair of pistols, and with stern features walked three times round his astonished suest. Wilson, however, gave no sign of alarm, whereupon the I) uke sat down, replaced the pistols in their case, and with a smile returned to his wine. The singular conduct, he said, had been assumed to try the courage of his visitor, and to ascertain whether the latter had been infected by the popular notion of his Grace's insanity. During the interview the Duke expressed a warm interest in education and learning, and offered his visitor his furtherance in any way that would benefit him. These kind expressions, however, remained without fruit, as the eccentric Duke, last of the lineal descent of the old Earls of Angus and Dourlas, died shortly afterwards.

Whilc at Lesmahagow Wilson developed his dramatic sketch into a tragedy entitled "Earl of Douglas"; and a descriptive sketch of the Nethan which he had written he expanded into his other and more famous poem of "Clyde." Both of these were printed at Glasgow in 1764 , and inscribed to Margaret, Duchess of Iouglas. In the same year the poet received a better paid appointment as classical teacher at Rutherglen, and there be devoted his leisure to the perfecting of his chief work. Ile had issued proposals for its re-publication when he was nominated to the position of master of the Grammar School of Greenock. llere occurred the second conspicuous incident in the poet's life. so deeply were the magistrates of Greenock still imbued with 
the narrow spirit of the early Calvinistic reformers that before they conferred the appointment they stipulated that Wilson should sign a paper promising to abandon the "profane and unprofitable art of poem-making." By this time Wilson was father of a family of nine, and the instincts of affection prevailed over the fire of poesie. He accepted the situation, loyally kept to his bond, and from that time, except for a casual improvization or two, sang no more. He died in 1789. In 1803 the poem of "Clyde" was edited, with the author's unpublished emendations, by Dr. John Leyden, and printed in a volume of Scottish Descriptive Poems.

The poem on which Wilson's fame rests is of the locodescriptive character, of the same class as Denham's "Cooper's Hill " and Pope's "Windsor Forest." Its chief fault probally is that it contents itself with the mere enumeration of natural objects, instead of bodying forth the human feelings which they inspire. For this reason the traditional and historical passages are apt to be perfunctory and uninteresting. Wilson's descriptions, however, are invariably true to nature, and again and again he has a picturesque passage well worthy of enduring remembrance.

\section{CLYDE.}

\section{A SUMMER DAY.}

WHEN Lucifer, unrivalled, marks his way Through fainting stars, to usher in the day, And soft-awakening morn, serenely bright, Pours from her opening eyes the silver light, Less huge the hills, the steeps less dreadful seem, O'er dewy valleys shoots a silver gleam, Brighter and wider dart the reddening rays, Till the pale stars expire amidst the blaze, And all the east, the veil of clouds unrolled, Flames bright in purple and celestial gold. Then, glorious as a hero drest for war, Forth issues Phoebus in his radiant car, 
Inflames the heavens, and, rushing on his way, O'erflows the world with blazing, boundless day. Each blushing flower, tinged eloud, and gilded field In various lustres grateful tributes yield. Glad swarm the insects forth, the fishes play, 'The cattle wanton, mankind bless his ray. Healthful and gay the shepherd leaves his rest As early morn first streaks the ruddy east ; His dogs attending, bounds the mountains o'er, Explores, collects, and counts his fleecy store, 'Then tunes his pipes, and with a cheerful lay' Joins the grand hymn to welcome rising day. The towering lark ascends on pinions strong, And as she mounts improves the varying song; Sweeter and sweeter modulates the sound, 'Till song and songster are in ether drowned. Her numbers clear the shepherd's mind employ Who sucks the soul of harmony and joy;

His harmless flock and tender lambs conspire 'To feed humanity's refining fire.

smooth glide his days in innocence and ease, The half of earth, and more of heaven he sees; $\Lambda$ s on the airy hill he lies reclined Each prospect swells his self-illumined mind.

At dawn the sprightly milk-maid band appears, Whose distant laugh strikes his delighted ears, All fresh as morn, as early summer gay, And sweetly fragrant as the breath of May. Health decks their comely cheeks with rosy grace, And innocence plays cheerful o'er their face. Iore lends his pinions, swift the shepherd springs, 
And to the fold the milky mothers brings.

Then frolic nymphs and swains with sportful glee;

Pure are their hearts and their behaviour free; The foaming pails, which snowy floods o'erflow, Raised on their heads, they singing homeward go.

See how their arms these sturdy mowers wield! How smooth behind them shines the ravished field: Swinging their formidable scythes around, Each sweep lays bare a mighty length of ground. Their work behind the active rakers ply, The fragrant herbs around them lightly fly ; The panting steeds drag slow the groaning wain, And deep the wheels imprint the yielding plain; The maids pile up the stack, while from below The hay into their arms their lovers throw.

The reapers next appear, a merry band; A sharp-toothed sickle shines in every hand. Subdued before them falls the yielding grain, Behind, long lines of sheaves load thick the plain. Band strives with band, and harmless dispute breeds; The rustic jest, the noisy laugh succeeds.

As they advance, their lord with lessening fear Sees crowned the hopes and labours of the year, And in his barn-yard lodged, a treasure shines, More precious than the wealth of Indian mines. His weary nymphs and swains behold him call 'To dear-earned banquet in his rustic hall; With ale and music their plain hearts they cheer, Dance, and forget the labours of the year. 
WHER: ancient Corehouse hangs above the stream, And far beneath the tumbling surges gleam, Engulphed in crags the fretting river raves, Chafed into foam resound his tortured waves. With giddy heads we view the dreadful deep, And cattle snort and tremble at the steep, Where down at once the foaming waters pour, And tottering rocks repel the deafening roar.

Viewed from below, it seems from heaven they fell; Seen from above, they seem to sink to hell;

But when the deluge pours from every hill, And Clyde's wide bed ten thousand torrents fill, His rage the murmuring mountain streams augment, Redoubled rage in rocks so closely pent. Then shattered woods, with ragged roots uptorn, And herds and harvests down the waves are bome. Huge stones heaved upward through the boiling deep, And rocks enormous thundering down the steep, In swift descent, fixed rocks encountering, roar, Crash as from slings discharged, and shake the shore. From that drear grot which bears thy sacred name, Heroic Wallace, ever dear to fame, 1)id I the terrors of the scene behold. I saw the liquid snowy mountains rolled Prone down the awful steep; I heard the din That shook the hill, from caves that boiled within. Then wept the rocks and trees, with dropping hair; 'Thick mists ascending, loaded all the air, 
Blotted the sun, obscured the shining day, And washed the blazing noon at once away. The wreck below, in wild confusion tossed, Convolved in eddies or in whirlpools lost, Is swept along, or dashed upon the coast.

THE BULL OF CADZOW.

WHERE these high walls round wide enclosures run, Forbid the winter, and invite the sun, Wild strays the race of bisons, white as snow, Hills, dales, and woods re-echo when they low. No houses lodge them, and no milk they yield Save to their calves, nor turn the furrowed field ; At pleasure through the spacious pastures stray, No keeper know, nor any guide obey, Nor round the dairy with swelled udders stand, Or, lowing, court the milk-maid's rosy hand. But mightiest of his race the bull is bred; High o'er the rest he rears his armed head. The monarch of the drove, his sullen roar Shakes Clyde with all his rocks from shore to shore. The murdered sounds in billowy surges come, Deep, dismal as the death-denouncing drum, When some dark traitor, 'mid an armed throng, His bier the sable sledge, is dragged along. Not prouder looked the Thunderer when he bore The fair Europa from the Tyrian shore. The beauteous heifers that his nod obey Match the famed heifers of the god of day. 
By Crookstone Castle waves the still-green yew, The first that met the royal Mary's view When, bright in charms, the youthful princess led The graceful Darnley to her throne and bed. Embossed in silver now, its branches green Transcend the myrtle of the Paphian queen.

But dark Langside, from Crookstone viewed afar, Still seems to range in pomp the rebel war. Here, when the moon rides dimly through the sky, The peasant sees broad, dancing standards fly; And one bright female form, with sword and crown, Still grieves to view her banners beaten down. 


\section{SIR GILBERT ELLIOT.}

I 722-1 777 .

The third baronet of Minto, to whose suggestion the older version of "The Flowers o' the Forest" is owed, was himself author of at least two songs-the one here given, which was very popular among the upper classes in Edinburgh about the middle of last century; and another on Colonel Gardiner, who fell at Prestonpans, which is one of the few ditties of that time on the Hanoverian side. Sir Gilbert was educated for the Scottish Bar, and held several official appointments. He died at Marseilles. His son, after acting as Governor-General of India, lecame the first Earl of Minto.

\section{MY SHEEP I NEGLECTED.}

MY sheep I neglected, I lost my sheep-hook, And all the gay haunts of my youth I forsook; No more for Amynta fresh garlands I wove, For ambition, I said, would soon cure me of love.

Oh, why had my youth with ambition to do? Why left I Amynta? why broke I my row?

Oh, give me my sheep, and my sheep-hook restore, And I'll wander from love and Amynta no more. 
Through regions remote in vain do I rove, And bid the wide ocean secure me from love. Oh fool! to imagine that aught could subdue A love so well founded, a passion so true!

Alas! 'tis too late at thy fate to repine; Poor shepherd! Amynta can never be thine. Thy tears are all fruitless, thy wishes are vain, The moments neglected return not again. 


\section{TOBIAS SMOLLETT.}

\section{72 I-I 77 I.}

It is rather as a novelist than as a poet that Tobias George Smollett is remembered; nevertheless, the author of "Roderick Random" and "Humphrey Clinker" was a noted writer of verse in his time, and has left at least two short pieces of classic rank.

Born at Dalquhurn House, near Renton, the child of a younger son who died early, the future novelist and poet was educated by his grandfather, Sir James Smollett of Bonhill. From the neighbouring Grammar School in Dunbarton he passed to Glasgow College, was apprenticed to a medical practitioner in that city, and is said even to have gone to purstie his studies at Edinburgh, when the death of his grandfather left him at the age of nineteen without means of support. Determining at the pinch to try literature as a profession, he betook himself to London with a play, "The Regicide," in his pocket. This, however, he failed to get a hearing for, and he was glad presently to accept the post of a surgeon's mate on an eighty-gun ship of war. In this capacity he was present at the disastrous siege of Carthagena, in South America. After an experience of six years he left the service in disgust. In Jamaica, where he then spent some time, he met the lady who became his wifeMiss Anne Lascelles, the Narcissa of "Roderick Random."

When Smollett returned to Britain in 1746 , the country was ringing with the report of the outrages perpetrated by the Duke of Cumberland on the Jacobite Highlanders. Fired with indignation and heedless of consequences, the whilom surgeon's mate penned what must be considered his finest poem, "The Tears of Scotland." The piece lrought him into notice, and presently, falling into emlarrassed circumstances through litigation over his wife's inheritance, and forced to literature for a living, he gave to the world his novel "Roderick Kandom," and followed it up with a variety of pulblications-political, medical, and imaginative. I Iis career was now entirely that of the luusy man of letters. In rapid succession he issued a series of works - a translation of "Don (Yuixote," a "Compendium of Voyages," a play "The keprisals," and a "Complete Histury 
of England." He also became editor of the "Critical Review," and when Admiral knowles prosecuted that periodical for an attack which it had made on him, Smollett stepped forward, avowed himself the author of the article, and submitted to the tine of $\oint_{100}$ and a sentence of three months' imprisonment. As a friend and supporter of Lord Bute, he started a weekly paper "The Briton," which involved him in more than one literary and political dispute. And after a stay of two years in France and Italy for the benefit of his health he published a "Tour," for which, with its petulant and captious spirit, he was satirized under the name of Smelfungus by Laurence Sterne. Driven again to Italy by failing strength in 1770 , he wrote, at Monte Nuova, near Leghorn, his last delightful work, "Humphrey Clinker," and at Leghorn itself, in October of the following year, he died.

As a man Smollett has been blamed for his testy and quarrelsome temper; and probably, to judge from the number of contentions in which he was engaged, the charge is not male unjustly. In the account of his life, however, there are several touches which reveal another side of his nature. At the height of his fame he went north to visit his mother, then living at Scotston, near Peebles. To test the old lady's perception he had himself introduced as a gentleman from the West Indies, and to carry out the deception, he assumed a frowning and forbidding aspect; but as Mrs. Smollett kept looking fixedly at him, the attempt gave way, and in a moment his mother's arms were about his neck as she exclaimed, "Oh, laddie, laddie, and you've come at last! That auld kent smile o' yours has letrayed ye." Another incident was the death of his only daughter, a girl of fifteen. By this event he was thrown into a despondency which seriously affected his health, and from which he never incleed recovered.

As a novelist he stands among the British classics, probably unsurpassed in his own region--an amusing delineation of the stronger humours and absurdities of character. As a poet, besides the two pieces upon which his chief fame rests, he was the author of several odes and songs, which are to be found under his name in Gilfillan's "British Poets" and other collections. These, however, have not the advantage of the perfervid patriotic spirit which warms and elevates the "Tears of Scotland" and the "Ode to Leven Water." Of the "Tears of Scotland" it is said Smollett had written six stanzas when a friend warned him of the danger of such free expression of patriotic feeling at the time. The poet's answer was to sit down and add a seventh of stronger invective than all the others put together. 


\section{THE TEARS OF SCOTLAND.}

Mours, hapless Caledonia! mourn

Thy banished peace, thy laurels torn:

Thy sons, for valour long renowned,

lie slaughtered on their native ground;

Thy hospitable roofs no more

Invite the stranger to the door!

In smoky ruins sunk they lie,

The monuments of cruelty.

The wretched owner sees afar

His all become the prey of war;

Bethinks him of his babes and wife,

Then smites his breast and curses life.

Thy swains are famished on the rocks

Where once they fed their wanton flocks;

Thy ravished virgins shriek in vain;

Thy infants perish on the plain.

What boots it then, in every clime,

Through the wide-spreading waste of time, Thy martial glory, crowned with praise,

Still shone with undiminished blaze? 
Thy towering spirit now is broke,

Thy neck is bended to the yoke.

What foreign arms could never quell,

By civil rage and rancour fell.

The rural pipe and merry lay

No more shall cheer the happy day;

No social scenes of gay delight

Beguile the dreary winter night;

No strains but those of sorrow flow,

And nought be heard but sounds of woe;

While the pale phantoms of the slain

Glide nightly o'er the silent plain.

Oh, baneful cause! oh, fatal morn, Accursed to ages yet unborn!

The sons against the father stood, 'The parent shed his children's blood. Yet, when the rage of battle ceased, 'The victor's soul was not appeased:

The naked and forlorn must feel l)evouring flames and murdering steel!

The pious mother, doomed to death, Forsaken, wanders o'er the heath; The bleak wind whistles round her head, Her helpless orphans cry for bread. Bereft of shelter, food, and friend, She views the shades of night descend, And, stretched beneath the inclement skies, Weeps o'er her tender babes, and dies. 
While the warm blood bedews my veins, And unimpaired remembrance reigns;

Resentment of my country's fate Within my filial breast shall beat; And spite of her insulting foe, My sympathising verse shall flow. Mourn, hapless Caledonia! mourn Thy hanished peace, thy laurels torn! 


\section{ODE TO LEVEN WATER.}

ON Leven's banks, while free to rove And tune the rural pipe to love, I envied not the happiest swain That ever trod the Arcadian plain.

Pure stream, in whose transparent wave My youthful limbs I wont to lave, No torrents stain thy limpid source, No rocks impede thy dimpling course, That warbles sweetly o'er its bed, With white, round, polished pebbles spread, While, lightly poised, the scaly brood In myriads cleave thy crystal floodThe springing trout in speckled pride, The salmon, monarch of the tide, The ruthless pike intent on war, The silver eel, and mottled par. Devolving from thy parent lake, A charming maze thy waters make, By bowers of birch and groves of pine, And edges flowered with eglantine. 
Still on thy banks, so gaily green, May numerous herds and flocks be seen, And lasses, chanting o'er the pail, And shepherds, piping in the dale, And ancient faith, that knows no guile, And Industry, embrowned with toil, And hearts resolved and hands prepared The blessings they enjoy to guard. 


\section{ADAM SKIRVING.}

\section{7 I 9-1 803 .}

For a characteristic undertone of pawkie sarcasm the Jacolite lallad of "Johnnie Cope" holds a place of its own in Scottish literature. The composition, with its spirit-stirring air, has been popular ever since the event which it records. The suljject is the overthrow of Sir John Cope and the forces of George II. by l'rince Charles Edward at Prestonpans, in Iladdingtonshire, on September 22, 1745. Sir John Cope, the general of the King's troops, allowed himself to be taken by surprise, suffered clisgraceful defeat, and galloping in panic from the field, carried everywhere with him, till he reached the walls of Berwick, the tidings of his own overthrow. For his conduct he was afterwards tried by court-martial, but was acquitted.

The author of the song, who also wrote another piece on the same subject under the title of "Tranent Muir," was a wealthy farmer of the neighbourhood, renowned for his skill in all manly sports and exercises. A story is told of him, how one, Lieutenant Smith, who had displayed great pusillanimity in the action, considering himself aggrieved by Skirving's muse, sent the author a challenge to fight him at Haddington. "Gang awa' back," said the farmer to the Lieutenant's envoy, "and tell Mr. Snith that I ha'e nae leisure to come to Haddington; but tell him to come here, and I'Il tak' a look o' him, and if I think I'm fit to fecht him, I'll fecht him ; and if no, I'll do as he did-l'll rin awa'."

The poet lies buried in the kirkyard of Athelstaneford, where his tombstone thus records his qualities-

\footnotetext{
"In feature, in figure, agility, mind, And happy wit rarely surpassed, With lofty or low could be plain or refined, Content beaming bright to the last."
} 


\section{JOHNNIE COPE.}

Cope sent a letter frae Dunbar: "Charlie, meet me an ye daur, And I'll learn you the art o' war, If you'll meet me in the morning."

Hey, Johnnie Cope, are ye wauking yet?

Or are your drums a-beating yet?

If ye were wauking I wad wait To gang to the coals i' the morning.*

When Charlie looked the letter upon, He drew his sword the scabbard from: "Come, follow me, my merry merry men, And we'll meet Johnnie Cope in the morning!

"Now, Johnnie, be as good's your word; Come, let us try both fire and sword; And dinna flee away like a frighted bird, That's chased frae its nest in the morning."

* The reference in this refrain has probally some connection with the chief industry of the neighbourhood at the time, the coal mines of Tranent being among the oldest in Scotland. 
When Johnnie Cope he heard o' this

He thought it wadna be amiss

To ha'e a horse in readiness

'lo flee awa' in the morning.

lye now, Johnnie, get up and rin;

'The Highland bagpipes mak' a din ;

It's best to sleep in a hale skin,

For 'twill be a bluidy morning.

When Johnnie Cope to Dunbar came

They speered at him, "Where's a' your men?"

"The deil confound me gin I ken,

For I left them a' i' the morning."

Now, Johnnie, troth, ye are na blate

To come wi' the news o' your ain defeat, And leave your men in sic a strait

Sae early in the morning.

"Oh, faith," quo' Johnnie, "I got sic flegs I 1 scares. Wi' their claymores and philabegs;

If I face them again, deil break my legs :

So I wish you a gude morning." 


\section{WILLIAM WILKIE.}

$1721-1772$.

The author of the once-talked-of poem, the Efigoniad, wats one of those Scotsmen, types of their race, who have attained their ends by incredible struggle through difficulties and obstacles. Recalled from Edinburgh University, by his father's death, to manage the farm and support his three sisters, he yet persevered with his studies, was licensed, and became minister of the parish of Ratho in Midlothian. Here he wrought his way to some reputation as a poet, though he certainly never deserved the title which Hume rashly conferred upon him of "the Scottish Homer." Alssent-minded, and uncouth in manners, though indeed kind of heart, he was but ill-fitted for the dignity of the pulpit. His sound qualities, howerer, got him the post of Professor of Natural Philosophy at St. Andrews, and in 1766 the University there conferred on him the degree of D.I). As professor he no doubt exercised considerable influence on the youth of the country. In particular he is known to have shown friendship towards Robert Fergusson, when a student in his class.

The Epigoniad, Wilkie's chief work, an ambitious epic in nine books descriptive of the siege of Thebes, appeared in 1757. Its inspiration was obviously owed to l'ope's translation of the Iliad and Odyssey, and it has many shortcomings not to be found in its model-Scotticisms, false rhymes and rhythm, and even flaws of language. Many passages, however, are conceived in singularly happy vein, and the story is vigorous and crisp. Wilkie also wrote a "Dream" in the manner of Spenser, and a volume of somewhat commonplace poetic fahles. I lis poems were included in Chalmers' English l'oets in 1810 .

\section{THE DEATH OF HERCULES.}

(From the Epigonial, Book vii.)

"The wife of Jove," Pronides replied, "All arts in vain to crush the hero tried; For brighter from her hate his virtue burned, And disappointed still the Cioddess mourned. 
His ruin to effect at last she strove By jealousy, the rage of injured love. The bane to Dejanira's breast conveyed, Who, as a rival, feared th' Echalian maid. The Goddess knew that, jealous of her lord, $A$ robe she kept with latent poisons stored'The centaur's gift, bequeathed her to reclaim The hero's love, and light his dying flame, If e'er, devoted to a stranger's charms, He strayed inconstant from her widowed arms; But given with treacherous intent to prove The death of nature, not the life of love. Mad from her jealousy, the charm she tried; His love to change, the deadly robe applied; And, guiltless of the present which he bore, Lychas conveyed it to Cenæum's shore, Where to the Powers immortal, for their aid, A grateful hecatomb the hero paid, When, favoured from above, his arm o'erthrew The proud Eurytus, and his warriors slew.

"The venomed robe the hero took, nor feared $\Lambda$ gift by conjugal respects endeared; And straight resigned the lion's shaggy spoils, 'The mantle which he wore in all his toils. No sign of harm the fatal present showed, Till roused by heat its secret renom glowed; Straight on the flesh it seized, like stiffest glue, And, scorching deep, to every member grew. Then, tearing with his hands th' infernal snare, His skin he rent, and laid the muscles bare, While streams of blood, descending from the wound, 
Mixed with the gore of victims on the ground.

The guiltless Lychas, in his furious mood,

He seized, as trembling by his side he stood;

Him by the slender ankle snatched, he swung,

And 'gainst a rocky promontory flung,

Which from the dire event his name retains.

Through his white locks, impurpled, rushed the brains.

"Awed by the deed, his desperate rage to shun, Our bold companions from his presence run. I, too, concealed behind a rock remained, My love and sympathy by fear restrained.

For furious midst the sacred fires he flew, The victims scattered, and the hearths o'erthrew.

Then sinking prostrate where a tide of gore From oxen slain had blackened all the shore, His form divine he rolled in dust and blood; His groans the hills re-echoed, and the flood. Then rising furious, to the ocean's streams He rushed, in hope to quench his raging flames; But burning still the unextinguished pain, The shore he left, and stretched into the main.

" A galley anchored near the beach we found; Her curled canvas to the breeze unbound; And traced his desp'rate course, till, far before, We saw him land on CEta's desert shore.

'Towards the skies his furious hands he reared, And thus, across the deep, his voice we heard: "Sovereign of heaven and earth, whose boundless sway

The fates of men and mortal things ohey! 
If e'er, delighted, from the courts above

In human form you sought Alcmena's love-

If Fame's unchanging voice to all the earth

With truth proclaims you author of my birth-

Whence, from a course of spotless glory run,

Successful toils, and wreaths of triumphs won,

Am I thus wretched? Better that, before,

Some monster fierce had drunk my streaming gore,

Or, crushed by Cacus, foe to gods and men,

My battered brains had strewed his rocky den,

Than, from my glorious toils and triumphs past,

To fall subdued by female arts at last.

O cool my boiling blood, ye winds, that blow

From mountains loaded with eternal snow,

And crack the icy cliffs! In vain, in vain!

Your rigour cannot quench my raging pain;

For round this heart the furies wave their brands,

Ind wring my entrails with their burning hands.

Now, bending from the skies, $\mathrm{O}$ wife of Jove!

Enjoy the vengeance of thy injured love;

For, Fate, by me, the Thunderer's guilt atones,

And, punished in her son, Alcmena groans.

'The object of your hate shall soon expire;

Fixed on my shoulders preys a net of fire.

Whom nor the toils nor dangers could subdue,

By false Eurystheus, dictated from you,

Nor tyrants lawless, nor the monstrous brood

Which haunts the desert or infests the flood,

Nor Greece, nor all the barbarous climes that lie

Where Phobus ever points his golden eye,

A woman hath o'erthrown! Ye Gods, I yield 
'To female arts, unconquered in the field! My arms! alas, are these the same that bowed Antæus, and his giant force subdued? 'Ihat dragged Nemea's monster from his den, And slew the dragon in his native fen? Alas, alas! their mighty muscles fail, While pains infernal every nerve assail. Alas, alas! I feel in streams of woe These eyes dissolved, before untaught to flow. Awake, my virtue! oft in dangers tried, Patient in toils, in deaths unterrifiedRouse to my aid; nor let my labours past, With fame achieved, be blotted at the last. Firm and unmoved the present shock endure; Once triumph, and for ever rest secure.' "The hero thus; and grasped a pointed rock With both his arms, which straight in pieces broke, Crushed in his agony; then on his breast Descending prostrate, further plaint supprest. "And now the clouds, in dusky volumes spread, Had darkened all the mountains with their shade; The winds withhold their breath; the billows rest; The sky's dark image on the deep impressed.

$A$ bay for shelter, opening in the strand, We saw, and steered our ressel to the land. Then mounting on the rocky beach above, Through the thick gloom descried the son of Jore. His head declined between his hands he leaned, His elbows on his bended knees sustained. Above him still a hovering vapour flew, Which from his boiling veins the garment drew. 
Through the thick woof we saw the funes aspire, like smoke of victims from the sacred fire. Compassion's keenest touch my bosom thrilled; My eyes a flood of melting sorrow filled.

Doubtful I stood; and pondering in my mind, By fear and pity variously inclined, Whether to shun the hero, or essay

With friendly words his torment to allay;

When, bursting from above with hideous glare, $A$ flood of lightning kindled all the air. From CEta's top it rushed in sulden streams; 'The ocean reddened at its fiery beams.

Then, bellowing deep, the thunder's awful sound Shook the firm mountains and the shores around.

Far to the east it rolled, a length of sky;

We heard Euboa's rattling cliffs reply.

"As at his master's voice a swain appears, When waked from sleep his early call he hears, The hero rose, and to the mountain turned, Whose cloud-involved top with lightning burned; And thus his sire addressed. " "With patient mind

Thy call I hear, obedient and resigned. Faithful and true the oracle which spoke In high Dodona from the sacred oak, That, teeenty years of painful labours past, On CEta's top I should repose at last. Before, involved, the meaning lay concealed; But now I find it in my fate revealed. Thy sovereign will I blame not, which denies With length of days to crown my victories. 
Though still, with danger and distress engaged,

For injured right eternal war I waged;

A life of pain, in barbarous climates led,

The heavens my canopy, a rock my bed.

More joy I've felt than delicacy knows

Or all the pride of regal pomp bestows.

Dread sire! thy will I honour and revere,

And own thy love with gratitude sincere,

Which watched me in my toils, that none could boast

To raise a trophy from $\mathrm{my}$ glory lost.

And though at last, by female arts o'ercome, And unsuspected fraud, I find my doom; There to have failed, my honour ne'er can shake, Where vice is only strong, and virtue weak.'

"He said, and turning to the cloudy height, The seat of thunder, wrapt in sable night, Firm and undaunted trod the steep ascent; An earthquake rocked the mountain as he went. Back from the shaking shores retired the flood: In horror lost my bold companions stood, To speech or motion. But the present power Of love inspired me in that awful hour. With trembling steps I traced the son of Jove, And saw him darkly on the steep above, Through the thick gloom. The thunder's awfut noise

Ceased, and I called him thus with feeble voice. ' $\mathrm{O}$ son of mighty Jove! thy friend await, Who comes to comfort thee, or share thy fate. In every danger and distress before, 
His part your faithful Philoctetes bore.

$O$ let me still attend you, and receive

The comfort which a present friend can give,

Who comes obsequious for your last commands,

And tenders to your need his willing hands.'

"My voice he heard, and from the mountain's brow

Saw me ascending on the steep below.

'To favour my approach his steps he stayed, And pleased amidst his anguish, smiling said,

'Approach, my Philoctetes! Oft I've known

Your friendly zeal in former labours shown.

'The present, more than all, your love proclaims,

Which braves the Thunderer's bolts and volleyed flames;

With daring step the rocking earthquake treads

While the firm mountains shake their trembling heads.

As my last gift, these arrows, with the bow, Accept; the greatest which I can bestow-My glory all my wealth-of power to raise Your name to honour and immortal praise, If for wronged innocence your shafts shall fly As Jove by signs directs them from the sky.'

"Straight from his mighty shoulders, as he spoke. He loosed and lodged them in a caverned rock, To lie untouched till future care had drained Their poison, from the venomed robe retained. And thus again:

'The only aid I need, For all my favours past the only meed, 
Is that, with vengeful hand you fix a dart

In cruel Dejanira's faithless heart.

Her treacherous messenger already dead,

Let her, the author of the crime, succeed.

'This awful scene forsake without delay;

In vain to mingle with my fate you stay.

No kind assistance can my state retrieve,

Nor any friend attend me, and survive.'

"The hero thus his tender care expressed,

And spread his arms to clasp me to his breast;

But soon withdrew them, lest his tainted veins

Infection had conveyed, and mortal pains.

Silent I stood in streams of sorrow drowned,

Till from my heart these words a passage found:

' $\mathrm{O}$ bid me not forsake thee, nor impose

What wretched Philoctetes must refuse.

By him I swear, whose presence now proclaim

The thunder's awful voice and forked flame-

Beneath whose steps the trembling desert quakes, And earth affrighted to her centre shakes.

I never will forsake thee, but remain

While struggling life these ruined limbs retain.

No form of fate shall drive me from thy side,

Nor death with all its terrors e'er divide;

Though the same stroke our mortal lives should end,

One flash consume us, and our ashes blend.'

"I spoke, and to the cloudy steep we turned.

Along its brow the kindled forest burned;

'The savage brood, descending to the plains,

'The scattered flocks, and dread-distracted swains

Rushed from the shaking cliffs; we saw them come, 
In wild disorder mingled, through the gloom. And now appeared the desert's lofty head,

A narrow rock, with forest thinly spread.

His mighty hands displayed aloft in air, To Jove the hero thus addressed a prayer:

'Hear me, dread Power, whose nod controls the skies,

At whose command the winged lightning flies!

Almighty sire! if yet you deign to own

Alcmena's wretched offspring as your son,

Some comfort in my agony impart,

And bid thy forked thunder rend this heart.

Round my devoted head it idly plays,

And aids the fire which wastes me, with its rays.

By heat inflamed, this robe exerts its power

My scorched limbs to shrivel and devour,

Upon my shoulders like a dragon clings,

And fixes in my flesh a thousand stings.

Great sire! in pity to my suit attend, And with a sudden stroke my being end.'

"As thus the hero prayed, the lightning ceased, And thicker darkness all the hill embraced. He saw his suit denied: in fierce despair The rooted pines he tore, and cedars fair; And from the crannies of the rifted rocks Twisted with force immense the stubborn oaks. Of these upon the cliff a heap he laid, And thus addressed me as I stood dismayed:

Behold, my friend! the ruler of the skies, In agony invoked, my suit denies. But sure the oracle inspired from heaven, 
Which in Dodona's sacred grove was given, The truth declared, that now my toils shall cease, And all my painful labours end in peace.

Peace death can only bring; the raging smart, Warped with my vitals, mocks each healing art. Not all the plants that clothe the verdant field, Not all the health a thousand mountains yield, Which on their tops the sage physician finds, Or, digging from the veins of flint, unbinds, This fire can quench. And therefore, to obey My last commands, prepare without delay. When on this pile you see my limbs composed, Shrink not, but hear what must not be opposed; Approach, and, with an unrelenting hand, Fix in the boughs beneath a flaming brand. I must not longer trust this madding pain, I.est some rash deed should all my glory stain. Lychas I slew upon the Crnian shore, Who knew not, sure, the fatal gift he bore. His guilt had taught him else to fly, nor wait Till from my rage he found a sudden fate.

I will not Dejanira's action blame;

Let heaven decide, which only knows her aim, Whether from hate, with treacherous intent, This fatal garment to her lord she sent; Or, by the cunning of a foe betrayed, His vengeance thus imprudently conveyed. If this, or that, I urge not my command, Nor claim her fate from thy avenging hand. 'To lodge my lifeless bones is all I crave, Safe and uninjured, in the peaceful grave.' 
"'This with a hollow voice and altered look, In agony extreme, the hero spoke. I poured a flood of sorrow, and withdrew Amid the kindled groves to pluck a bough, With which the structure at the base I fired.

"On every side the pointed flames aspired; But ere involving smoke the pile enclosed, I saw the hero on the top reposed, Serene as one who, near the fountain laid, At noon enjoys the cool refreshing shade. The venomed garment hissed; its touch the fires Avoiding, sloped oblique their pointed spires. On every side the parted flame withdrew, And levelled, round the burning structure flew. At last, victorious to the top they rose,Firm and unmoved the hero saw them close. His soul, unfettered, sought the blest abodes, By virtue raised to mingle with the gods. His bones in earth with pious hands I laid; The place to publish nothing shall persuade, Lest tyrants, now unawed, and men unjust, With insults should profane his sacred dust. E'er since, I haunt this solitary den, Retired from all the busy paths of men; For these wild mountains only suit my state, And soothe, with kindred gloom, my deep regret." 


\section{THONAS BLACKLOCK.}

$$
\text { I } 721-1791 \text {. }
$$

A poet whose verse remains little more than an echo of the prevailing fashion in poetry of his time, the venerable Dr. Blacklock keeps name and fame among eighteenth century singers chiefly by reason of one fact. It was he whose prompt recognition of the genius of Burns arrested that poet on the eve of his departure from Scotland, and effected his introduction to Edinburgh and the greater world of letters.

The son of humble parents who were natives of Cumberlandhis father was a bricklayer-Blacklock was born at Annan in Dumfriesshire. When only six months old an attack of smallpox left him blind, and it might have been thought that for the rest of his days he was doomed to the fate of a pauper. II is spirit, however, proved itself capable of better things, and throughout life his amiability continually secured him friends who did all in their power to help his interests. At the age of twelve he was writing poetry, and though when he was nineteen his father was killed, his promise attracted a patron in the person of I)r. Stevenson, an eminent physician, who carried him to Edinburgh and supported him there for four years at the Grammar School. He found means also to attend the University, and qualify for the church. Among his friends in Edinburgh was David Hume the historian, who went so far as give up to him his salary as librarian of the Faculty of Advocates. Spence, too, the professor of poetry at Oxford, and friend of Pope, took great pains to introduce Blacklock's verse to the English public; while Beattie, the author of The Minstrel, got him the degree of D.I. from the University of Alserdeen.

In 1762 l3lacklock married, and at the same time was presented to the parish of Kirkcudbright. IIis settlement was resisted, however, on account of his blindness. For many years subsequently the chief part of his livelihood was gained by the keeping of a better-class boarding-school in Edinburgh. Two years after his death an edition of his poems was pullished, with a life by Henry Mackenzie, the author of "The Man of Feeling." Itis work is also included in Chalmers' English lioets, vol. v. 


\section{ON EUANTHE'S ABSENCE.}

AN ODE.

BufEST Heaven! and thou fair world below!

Is there no eure to soothe my smart?

No balm to heal a lover's woe,

That bids his eyes for ever flow,

Consumes his soul, and pines his heart?

And will no friendly arm above

Relieve my tortured soul from love?

As swift-descending showers of rain

Deform with mud the clearest streams-

As rising mists Heaven's azure stain,

Tinged with Aurora's blush in vain-

As fades the flower in mid-day beams;

On life thus tender sorrows prey,

And wrap in gloom its promised day.

Ve plains where dear Euanthe strays,

Ye various objects of her view,

Bedecked in Beauty's brightest blaze,

Let all its forms and all its rays,

Where'er she turns, her eyes pursue!

All fair as she let nature shine:

Ah: then, how lovely! how divine! 
Where'er the thymy vales descend,

And breathe ambrosial fragrance round, Proportion just, thy line extend, And teach the prospect where to end;

While woods or mountains mark the bound. That each fair scene which strikes her eye May charm with sweet variety.

Ye streams that in perpetual flow

Still warble on your mazy way,

Murmur Euanthe as you go-

Murmur a love-sick poet's woe.

Ye feathered warblers, join the lay;

Sing how I suffer, how complain; Yet name not him who feels the pain.

And thou, eternal ruling Power !

If spotless virtue claims thy care, Around unheard-of blessings shower, Let some new pleasure crown each hour And make her blest, as good and fair. Of all thy works to mortals known The best and fairest she alone. 


\section{HAPPY MARRIAGE.}

'THou genius of commubial love, attend!

Let silent wonder all thy powers suspend, Whilst to thy glory I devote my lays, And pour forth all my grateful heart in praise.

In lifeless strains let vulgar satire tell That marriage oft is mixed with heaven and hell, That conjugal delight is soured with spleen, And peace and war compose the varied scene.

My muse a truth sublimer can assert, And sing the triumphs of a mutual heart.

'Thrice happy they who through life's varied tide With equal pace and gentle motion glide, Whom, though the wave of fortune sinks or swells, One reason governs and one wish impels, Whose emulation is to love the best, Who feel no bliss but in each other blest, Who know no pleasure but the joys they give, Nor cease to love but when they cease to live. If fate these blessings in one lot combine, 'Then let th' eternal page record them mine. 


\section{JOHN SKINNER.}

I 72 I-I 807 .

For sixty-five years pastor of the episcopal chapel of Longside, near Peterhead in Aberdeenshire, the Rev. John Skinner experienced all the persecution accorded to non-jurors in his day. He was one of those who during the lifetime of the exiled Stuarts refused to take the oath of allegiance to the reigning house. For this conduct on one occasion his chapel was destroyed and his house wrecked, while he himself suffered six months' imprisonment. At other times he evaded the law forbidding a non-juring clergyman to officiate in a place of worship holding more than four persons, by reading the service at his open window to a congregation gathered outside. Nevertheless, amid all his difficulties and upon a very scanty stipend, he managed, in his small cottage at Linshart, to rear a large welldoing family; and he lived to see one of his sons appointed Bishop of Alberdeen, the very diocese in which he had himself suffered so much. A man of piety and scholarship, as a recent writer has remarked, "this master of a 'but and ben' with no floor to it, had both wit and will in his hearl and wisdom in his heart. Nor did there perhaps exist a man to whom all descriptions of people took off their hats and caps with a more zealous respect." By another writer Skinner has been compared for his upright and simple character to the type of Dr. l'rimrose and Parson Adams, and a story is told of him which well illustrates his tolerant and sensible spirit. He was one day, it appears, passing a dissenting place of worship, and hearing from within the sounds of psalmody, he reverently took off his that. "What!" said a friend at his side, "are you so fond of the Anti-lurghers?" "Sir," replied the old clergyman wilh some warmith, "I respect and love any of my fellow -Christians who are engaged in singing to the glory of the Lord Jesus Christ."

Born at IBalfour, in the parish of Birse, Aberdeenshire, where his father was schoolmaster, Skinner was never probably, in all his life, very far from home. One journey only is recorded of 
him, when he went as a tutor to Shetland, and brought home as his wife the daughter of the episcopal clergyman there. He was, however, the author of a number of songs which have carried his name wherever there are Scottish lips to sing. Ili best-known piece, "Tullochgorum," printed first in the Scot Weekly Magazine in April, 1776, Burns called "the best Sicots song Scotland ever saw." The circumstances of its production are thus recorted:--Skinner with some friends had gone to dine at the house of an excise officer named Montgomerie, in the little $\Delta$ berdeenshire village of Ellon. After dinner the talk becomingr political, and threatening to grow warm, the hostess with womanly tact diverted it by a reference to the fine old tune of Tullochgrorum, and a suggestion that Mr. Skinner should fit it with better words than those in use. This he forthwith did, and the result remains. "The Ewie wi' the crookit horn," again, was suggested and indeed begun by Beattie, who, asked to write a pastoral, produced the first three lines, and then sent them to Skinner as the person best qualified to finish the piece. Others of Skinner's productions are "John o' Badenyon," " "Tune your fiddles," and "Lizy Liberty," to be found in every Scots song book. Ilis longest poem, "The Moneymusk Christmas Ba'ing," a composition on the model of "Christ's Kirk on the Green," was printed first in Shireff's Caledonian Magazine. The poet also engaged in a racy correspondence with Burns, whom, to the regret of both, he never met. Among his prose works were a learned Eiclesiastical History of Scotland and a treatise on the Hebrew Shechinah, the latter written during his confinement in Aberdeen gaol. He was buried at Longside, where a handsome monument marks his grave.

Two years after Skinner's death a collection of his poems was published at Edinburgh under the title, Amusements of Leisure Hours. The kev. William Walker of Moneymusk wrote a Life of the poet, of which a second edition was printed in $188_{3}$.

\section{TULLOCHGORUM.}

Come, gi'e 's a sang, Montgom'rie cried, And lay your disputes a' aside; What signifies for folks to chide For what was done before them? N 
Let Whig and Tory a' agree,

Whig and Tory, Whig and Tory,

Whig and Tory a' agree

To drap their whigmigmorum;

Let Whig and Tory a' agree

To spend this night in mirth and glee,

And cheerfu' sing, alang wi' me,

The reel o' 'Tullochgorum.

1 surly fool.

O Tullochgorum's my delight ;

It gars us a' in ane unite;

And ony sumph ${ }^{\mathrm{r}}$ that keeps up spite,

In conscience I abhor him.

Blithe and merry we'll be a',

Blithe and merry, blithe and merry,

Blithe and merry we'll be a'

And mak' a cheerfu' quorum.

For blithe and merry we'll be a'

As lang as we ha'e breath to draw, And dance, till we be like to fa',

The reel o' Tullochgorum.

sto do.

3 drawling.

4 sad and doleful.
What needs there be sae great a fraise ${ }^{2}$

Wi' dringin's, dull Italian lays?

I wadna gi'e our ain strathspeys

For half a hunder score $o$ ' them.

They're dowf and dowie at the best,

Dowf and dowie4, dowf and dowie,

Dowf and dowie at the best,

Wi' a' their variorum. 
'They're dowf and dowie at the best, 'Their allegros and a' the rest;

They canma please a Scottish taste Compared wi' 'Tullochgorum.

Let worldly worms their minds oppress

IVi' fears o' want and double cess,

And sullen sots themsel's distress

Wi' keeping up decorum.

Shall we sae sour and sulky sit?

Sour and sulky, sour and sulky,

Sour and sulky shall we sit,

Like auld philosophorum?

Shall we sae sour and sulky sit,

IIi' neither sense, nor mirth, nor wit,

Nor ever rise to shake a fit

'To the reel o' 'Tullochgorum?

May choicest blessings aye attend Each honest, open-hearted friend, And calm and quiet be his end,

And a' that's gude watch o'er him!

May peace and plenty be his lot, Peace and plenty, peace and plenty, . l'eace and plenty be his lot,

And dainties a great store o' them:

May peace and plenty be his lot, Unstained by ony vicious spot, And may he never want a groat, 'That's fond o' Tullochgorum ! 
But for the discontented fool, Wha wants to be oppression's tool, May envy gnaw his rotten soul, And discontent derour him!

May dule and sorrow be his chance, Dule and sorrow, dule and sorrow; Dule and sorrow be his chance, And nane say "Wae's me for him!" May dule and sorrow be his chance, And a' the ills that come frae France, Whac'er he be that winna dance The reel o' Tullochgorum! 


\section{THE}

\section{EIVIE WI' 'THE CROOKIT HORN.}

WERE I but able to rehearse

My ewie's praise in proper verse,

I'd sound it forth as loud and fierce

As ever piper's drone could blaw.

The ewie wi' the crookit horn!

Wha had kent her might ha' sworn

Sic a ewe was never born

Here about nor far awa'.

I never needed tar nor keil

'To mark her upo' hip or heel;

Her crookit hornie did as weel,

To ken her by amang them a'.

She never threatened scab nor rot,

But keepit aye her ain jog-trot;

Baith to the fauld and to the cot

Was never sweirt ${ }^{1}$ to lead nor $\mathrm{ca}^{2}$. $\quad \begin{aligned} & \text { 'backward. } \\ & 2 \text { drive. }\end{aligned}$ 
1 overcame her.

2 week.

3 notwithstanding the dog.

4 moved slowly. and cautiously:
Cauld nor hunger never dang her ${ }^{\mathrm{I}}$, Wind nor weet could never wrang her; Ance she lay an ouk ${ }^{2}$, and langer, Furth aneath a wreath o' snaw.

Whan ither ewies lap the dyke, And ate the kale, for a' the tyke ${ }^{3}$; My ewie never played the like, But tyced 4 about the barn wa'.

$A$ better or a thriftier beast

Nae honest man could weel ha'e wist :

5 frail.

For, silly 5 thing, she never missed

To ha'e, ilk year, a lamb or twa.

The first she had I ga'e to Jock,

To be to him a kind o' stock;

And now the laddie has a flock

O' mair nor thirty head ava'.

I lookit aye at even for her,

6 evil-doer.

7 pole-cat.

Lest mischanter ${ }^{6}$ should come o'er her,

Or the foumart 7 might devour her,

Gin the beastie bade awa'.

My ewie wi' the crookit horn

${ }^{8}$ gran.
Weel deserved baith gerss ${ }^{8}$ and corn;

Sic a ewe was never born

Here about or far awa'. 
Yet, last ouk, for a' my keeping,

(Wha can speak it without greeting?)

$A$ villain cam' when I was sleeping, Sta' my ewic, horn and a'.

I sought her sair upo' the morn; And down aneath a buss o' thorn I got my ewie's crookit horn, But my ewie was awa'.

O! gin I had the loun that did it, Sworn I have, as well as said it, Though a' the warld should forbid it, I wad gi'e his neck a thraw.

I never met wi' sic a turn

As this, sin' ever I was born;

My ewie wi' the crookit horn, Silly ewie, stown awa'.

O! had she dee'd o' crook or cauld, As ewies do when they are auld, It wadna been, by mony fauld, Sae sair a heart to nane o's a'.

For a' the claith that we ha'e worn, Frae her and her's sae aften shorn, The loss o' her we could ha'e borne, Had fair strae-death ta'en her awa'. 
But thus, puir thing, to lose her life, Aneath a bloody villain's knife;

I afraid.

I'm really fley't ' that our gudewife will never win aboon't ava's.

O ! a' ye bards benorth Kinghorn, Call your muses up and mourn Our ewie wi' the crookit horn, Stown frae's, and fell't, and a'! 


\section{JOHN HOME.}

\section{$1724-1808$.}

The author of "Douglas" remains famous for several reasons. lle was the successor of Blair, the author of The Grave, as minister of the parish of $A$ thelstaneford, and it was he who, on the bowling-green at Moffat, "discovered" Macpherson, and so brought alout the translation and publication of "Ossian." But his chief claim to remembrance lies in the fact that his was the first decided voice of the Romantic movement in British poetry. IIe may also be said to have been the founder of modern melodrama. It was he who brought alout the return to emotion for effect upon the stage, as Ramsay and Thomson brought about the return to emotion for effect in other fields of poetry.

A native of Leith, Home first attracted notice by an adventure of his student days. Along with a few companions he had gone out from Edinluurgh to watch the battle of Falkirk, and on the issue of that fight the party was captured by the Jacolites and confined in the castle of Doune. From an upper chamber of the castle, still pointed out, they escaped by tying their bedclothes together, and sliding at great hazard from the window to the ground.

The poet was not long settled at $A$ thelstaneford when his dramatic genius asserted itself. Since Sir David Lyndsay's time the drama had been silent in Scotland. One reason which has been assigned for this is that Scotland had ceased to be a separate country before the theatre reached its full birth; and after that birth the stern spirit of Calvinism forbade an audience, even if there had been a poet who could write plays. Allan Ramsay was all but ruined by the attempt to establish a theatre in Edinburgh; and the prospect before a minister of the kirk who should so far forget himself as to have anything to do with the stage, was at that time anything but reassuring. Undeterred by his knowledge of this fact, Home produced a tragedy entitled "Agis," and travelled in person to London to offer it to (iarrick. The piece was not accepted, and a subsequent journey south in 1755 with the tragedy of "Douglas" had no better result. Home then tried the Edinburgh stage, and there his play met with immediate and enthusiastic success. 
While his play gained Home fane, however, it lost him his living ; for its most immediate result was to raise a hornet's nest which drove him from the kirk, and involved in severe censure several clerical friends broad-minded enough to countenance him. More fortunate, however, than many another object of persecution, he was now independent of his cavillers. In June, 1757, he removed to London, and there, countenanced by the Bute administration, from which he received a pension, he staged in succession his plays of "Agis" and "The Siege of Aquileia." The year 1762 saw him back in Scotland, where he produced three further plays-."The Fatal Discovery," "Alonzo," and "Alfred." Of these the last-named was put upon the boards in 1778, and marked the close of its author's dramatic career. In that year Home had a fall from his horse, and received injury to his head which made further stage-writing impossible. He continued, nevertheless, to be a well-known figure in Edinburgh literary society, and was able to write a "History of the Rebellion of 1745." At his villa, near Edinburgh, Sir Walter Scott in his young days was a frequent guest. The best account of the author of "Douglas" in these latter years is perhaps that given in an article by Scott in the Quarterly Reziew in 1827 .

Home died in 1808 . Seventeen years later his complete works were published with a "life" by Henry Mackenzie. None of his plays is destitute of fine passages. Of them all, the "Siege of Aquileia," has by some critics been considered the best, containing truer sentiment than the others, and less play to the gallery. But "Douglas" is the only one remembered. Scott's criticism of Home's works, in his diary, runs-."Good blank verse, and stately sentiment, but something lukewarmish, excepting 'Douglas,' which is certainly a masterpiece. Even that does not stand the closet : its merits are for the stage."

The tragedy of "Douglas" is founded on the well-known ballad of "Gil Morice," printed first in P'ercy's Reliques, in 1765. According to tradition the scene of the ballad was the ancient forest of Dundaff, on the water of Carron, in Stirlingshire. (For the ballad, and particulars regarding it, see Siottish Ballad Poetry', p. 107, Abbotsford Series.) 


\section{I)OUGLAS.}

[lady Kanclolph, heiress of Sir Malcolm of Balarmo, had in her youth secretly married Douglas, a son of the enemy of her house. IIter hushand, after three weeks' wedlock, was slain in battle, and her child, sent away for concealment, is supposed to have been lost with his nurse in crossing the waler of Carron. The lady, rescued later from the arms of an unknown ravisher by lord Randolph, has been induced to bestow on her rescuer her hand and estates. She afterwards discovers her would-he ravisher in the person of (ilenalvon, Lord Randolph's heir; but out of consideration for her husband she conceals the facl. Cilenalvon presently sets an ambush to assassinate Lord kandolph; but the attack is frustrated ly the bravery of a shepherd youth. This youth, Norval, is privately discovered by lady kandolph to be her own long-Iost son.]

\section{AC'T I I .}

Sicene I. A Court. Flourish of Trumpets.

Enter LORD RANDOLPH, attended.

Ran. Summon an hundred horse by break of day; To wait our pleasure at the castle gate.

\section{Enter LADI RANIOIPH.}

Lady. Alas, my lord: I've heard unweleome news; The Danes are landed.

Ran. Ay, no inroad this Of the Northumbrian, bent to take the spoil; No sportive war, no tournament essay Of some young knight resolved to break a spear 
And stain with hostile blood his maiden arms. The Danes are landed; we must beat them back, Or live the slaves of Denmark.

Lady. Dreadful times!

Ran. The fenceless villages are all forsaken; The trembling mothers and their children lodged In wall-girt towers and castles; whilst the men Retire indignant. Yet, like broken waves, They but retire more awful to return.

Lady. Immense, as fame reports, the Danish host! Ran. Were it as numerous as loud fame reports, An army knit like ours would pierce it through. Brothers, that shrink not from each other's side, And fond companions, fill our warlike files; For his dear offspring, and the wife he loves, The husband, and the fearless father arm:

In vulgar breast heroic ardour burns, And the poor peasant mates his daring lord.

Lady. Men's minds are tempered, like their swords, for war ;

Lovers of dangers, on destruction's brink They joy to rear erect their daring forms.

Hence early graves; hence the lone widow's life, And the sad mother's grief-embittered age. Where is our gallant guest?

Ran. Down in the vale I left him managing a fiery steed, Whose stubbornness had foiled the strength and skill Of every rider. But behold he comes, In earnest conversation with (ilenalvon. 


\section{Enter NORVAl and (iLNNAIION.}

Glenalvon, with the lark arise; go forth, And lead my troops that lie in yonder vale;

Private I travel to the royal camp:

Norval, thou go'st with me. But say, young man, Where didst thou learn so to discourse of war, And in such terms as I o'erheard to-day? War is no village science, nor its phrase A language taught among the shepherd swains. Noro. Small is the skill my lord delights to praise In him he favours. Hear from whence it came. Beneath a mountain's brow, the most remote And inaccessible by shepherds trod, In a deep cave, dug by no mortal hand, A hermit lived, a melancholy man, Who was the wonder of our wandering swains. Austere and lonely, cruel to himself, Did they report him; the cold earth his bed, Water his drink, his food the shepherd's alms. I went to see him, and my heart was touched With reverence and pity. Mild he spake, And, entering on discourse, such stories told, As made me oft revisit his sad cell. For he had been a soldier in his youth, And fought in famous battles, when the peers Of Europe, by the bold Godfredo led, Against th' usurping Infidel displayed The blessed cross, and won the Holy Land. Pleased with my admiration, and the fire His speech struck from me, the old man would shake 
His years away, and act his young encounters:

'Then, having showed his wounds, he'd sit him down, And all the live-long day discourse of war.

To help my fancy, in the smooth green turf He eut the figures of the marshalled hosts; Described the motions, and explained the use Of the deep column, and the lengthened line, The square, the crescent, and the phalanx firm. For all that Saracen or Christian knew Of war's vast art, was to this hermit known. Ran. Why did this soldier in a desert hide Those qualities that should have graced a camp?

Norv. That too at last I learned. Unhappy man! Returning homeward by Messina's port, Loaded with wealth and honours bravely won, A rude and boist'rous captain of the sea Fastened a quarrel on him. Fierce they fought; The stranger fell, and, with his dying breath, Declared his name and lineage. Mighty God! The soldier cried, My brother! oh, my brother:

Lady. His brother!

Norv. Yes; of the same parents born; His only brother. They exchanged forgiveness; And happy in my mind was he that died; For many deaths has the survivor suffered. In the wild desert on a rock he sits, Or on some nameless stream's untrodden lanks, And ruminates all day his dreadful fate. At times, alas! not in his perfect mind, Holds dialogues with his loved brother's ghost; And oft each night forsakes his sullen couch, 
To make sad orisons for him he slew.

Lady. To what mysterious woes are mortals born!

In this dire tragedy were there no more

Unhappy persons? Did the parents live?

Norv. No: they were dead; kind Ileaven had closed their eyes

Before their son had shed his brother's blood.

Ran. Hard is his fate; for he was not to blame. There is a destiny in this strange world, Which oft decrees an undeserved doom:

Let schoolmen tell us why.

[Trumpets at a distance.

From whence these sounds?

\section{Enter an OfFICER.}

Off. My lord, the trumpets of the troops of Lorn: Their valiant leader hails the noble Randolph.

Ran. Mine ancient guest! does he the warriors lead? Has Denmark roused the brave old knight to arms?

Off. No; worn with warfare, he resigns the sword; His eldest hope, the valiant John of Lorn, Now leads his kindred bands.

Ran. Glenalvon, go.

With hospitality's most strong request

Entreat the chief. [Exit Glenalyon.

Off. My lord, requests are vain.

He urges on, impatient of delay,

Stung with the tidings of the foe's approach.

Ran. May victory sit upon the warrior's plume! Bravest of men; his flocks and herds are safe; Remote from war's alarms his pastures lie, 
By mountains inaccessibly secured;

Yet foremost he into the plain descends,

Eager to bleed in battles not his own.

Such were the heroes of the ancient world;

Contemners they of indolence and gain;

But still, for love of glory and of arms,

Prone to encounter peril, and to lift

Against each strong antagonist the spear.

I'll go and press the hero to my breast.

[Exit with OFFICER.

Lady. 'The soldier's loftiness, the pride and pomp Investing awful war, Norval, I see

Transport thy youthful mind.

Norv. Ah, should they not?

Blest be the hour I left my father's house!

I might have been a shepherd all my days,

And stole obscurely to a peasant's grave.

Now, if I live, with mighty chiefs I stand;

And, if I fall, with noble dust I lic.

Lady. There is a generous spirit in thy breast

That could have well sustained a prouder fortune.

Since lucky chance has left us here alone,

Unseen, unheard, by human eye or ear,

I will amaze thee with a wondrous tale.

Norv. Let there be danger, lady, with the secret, That I may hug it to my grateful heart, And prove my faith. Command my sword, my life; These are the sole possessions of poor Norval.

Lady. Know'st thou these gems?

Norv. Durst I believe mine eyes,

I'd say I knew them, and they were my father's. 
Lady. Thy father's say'st thou? ah! they were thy father's!

Nori. I saw them once, and curiously inquired Of both my parents, whence such splendour came. But I was checked, and more could never learn.

Lady. 'Then learn of me, thou art not Norval's son. Norv. Not Norval's son!

Lady. Nor of a shepherd sprung.

Nori: Lady, who am I, then?

Lady. Noble thou art, For noble was thy sire.

Nori. I will believe-

Oh tell me further! Say, who is my father?

Lady. Douglas!

Norv. Lord Douglas whom to-day I saw?

Lady. His younger brother.

Norv. And in yonder camp?

Lady. Alas!

Norz. You make me tremble-Sighs and tearsLives my brave father?

Lady. Ah, too brave indeed!

$\mathrm{He}$ fell in battle ere thyself was born.

Nori. Ah me, unhappy ere I saw the light!

But does my mother live? I may conclude From my own fate, her portion has been sorrow.

Lady. She lives, but wastes her life in constant woe, Weeping her husband slain, her infant lost.

Nor: You that are skilled so well in the sad story Of my unhappy parents, and with tears

Bewail their destiny, now have compassion Upon the offspring of the friends you loved. 
Oh ! tell me who and where my mother is!

Oppressed by a base world, perhaps she bends Beneath the weight of other ills than grief, And, desolate, implores of heaven the aid Her son should give. It is, it must be so:

Your countenance confesses that she's wretched. Oh, tell me her condition! Can the swordWho shall resist me in a parent's cause?

Lady. Thy virtue ends her woe-My son, my son! Norv. Art thou my mother?

Lady. I am thy mother, and the wife of Douglas. [Falls upon his neck.

Norv. O heaven and earth, how wondrous is my fate!

Ever let me kneel!

Lady. Image of Douglas! fruit of fatal love! All that I owe thy sire I pay to thee.

Norv. Respect and admiration still possess me, Checking the love and fondness of a son. Yet I was filial to my humble parents. But did my sire surpass the rest of men, As thou excellest all of womankind?

Lady. Arise, my son. In me thou dost behold The poor remains of beauty once admired. The autumn of my days is come already, For sorrow made my summer haste away; Yet in my prime I equalled not thy father. His eyes were like the eagle's, yet sometimes Liker the dove's; and, as he pleased, he won All hearts with softness, or with spirit awed. Nory. How did he fall? sure 'twas a bloody field 
When Douglas died! Oh, I have much to ask:

Lady. Hereafter thou shalt hear the lengthen'd tale Of all thy father's, and thy mother's woes.

At present this: thou art the rightful heir

Of yonder castle, and the wide domains,

Which now I.ord Randolph, as my husband, holds. But thou shalt not be wronged. I have the power To right thee still. Before the king I'll kneel, And call Lord Douglas to protect his blood.

Nory. The blood of Douglas will protect itself.

Lady. But we shall need both friends and favour, boy,

To wrest thy lands and lordship from the gripe

Of Randolph and his kinsman. Yet I think My tale will move each gentle heart to pity, My life incline the virtuous to believe.

Nori. To be the son of Douglas is to me Inheritance enough. Declare my birth, And in the field I'll seek for fame and fortune.

Lady. 'Thou dost not know what perils and injustice Await the poor man's valour. $\mathrm{Oh}$, my son! 'The noblest blood in all the land's abashed, Having no lackey but pale porerty.

Too long hast thou been thus attended, Douglas;

'Too long hast thou been deemed a peasant's child.

The wanton heir of some inglorious chief

Perhaps has scorned thee in thy youthful sports,

Whilst thy indignant spirit swelled in vain.

Such contumely thou no more shalt bear;

But how I purpose to redress thy wrongs

Must be hereafter told. Prudence directs 
That we should part before yon chief's return.

Retire, and from thy rustic follower's hand Receive a billet, which thy mothcr's care, Anxious to see thee, dictated before This casual opportunity arose

Of private conference. Its purport mark:

For, as I there appoint, we meet again.

Leave me, my son; and frame thy manners still To Norval's, not to noble Douglas' state.

Noro. I will remember. Where is Norval now, That good old man?

Lady. At hand concealed he lies,

An useful witness. But beware, my son,

Of yon Glenalvon; in his guilty breast

Resides a villain's shrewdness, ever prone

To false conjecture. He hath grieved my heart.

Norv. Has he indeed? Then let yon false Glenalvon Beware of me.

[Evit.

Lady. There burst the smothered flame.

$\mathrm{O}$ thou all-righteous and eternal king!

Who father of the fatherless art called,

Protect my son :-Thy inspiration, I.ord !

Hath filled his bosom with that sacred fire

Which in the breasts of his forefathers burned;

Set him on high like them, that he may shine

The star and glory of his native land!

Then let the minister of death descend,

And bear my willing spirit to its place.

Yonder they come. How do bad women find

Lnchanging aspects to conceal their guilt,

When I, by reason and by justice urged, 
Full hardly can dissemble with these men In nature's pious cause?

\section{Enter LoRI) Ranholph and Glenalvon.}

Ran. Yon gallant chief,

()f arms enamoured, all repose disclaims.

lad!. Be not, my lord, by his example swayed. Arrange the business of to-morrow now, And when you enter speak of war no more. [Exit. $R a n$. 'Tis so, by Heaven! her mien, her voice, her eye,

And her impatience to begone confirm it.

Glen. He parted from her now: Behind the mount, Amongst the trees, I saw him glide along.

Ran. For sad sequestered virtue she's renowned. Glen. Most true, my lord.

Ran. Yet this distinguished dame Invites a youth, th' acquaintance of a day, Alone to meet her at the midnight hour. This assignation-- Shozes a letter $]$ the assassin freed-Her manifest affection for the youth, Might breed suspicions in a husband's brain, Whose gentle consort all for love had wedded.

Much more in mine. Matilda never loved me.

Let no man after me a woman wed Whose heart he knows he has not; though she brings A mine of gold, a kingdom for her dowry.

For, let her seem like the night's shadowy queen, Cold and contemplative-he cannot trust her; She may, she will, bring shame and sorrow on him; The worst of sorrow and the worst of shames. 
Glen. Yield not, my lord, to such afflicting thoughts, But let the spirit of a husband sleep

Till your own senses make a sure conclusion.

This billet must to blooming Norval go.

At the next turn awaits my trusty spy;

I'll give it him refitted for his master.

In the close thicket take your secret stand;

The moon shines bright, and your own eyes may judge

Of their behaviour.

Ran. Thou dost counsel well.

Glen. Permit me now to make one slight essay: Of all the trophies which vain mortals boast, By wit, by valour, or by wisdom won, The first and fairest in a young man's eye Is woman's captive heart. Successful love With glorious fumes intoxicates the mind, And the proud conqueror in triumph mores, Air borne, exalted above vulgar men.

Ran. And what avails this maxim?

Glen. Much, my lord!

Withdraw a little: I'll accost young Norval, And with ironical derisive counsel Explore his spirit. If he is no more Than humble Norval, by thy fawour raised, Brave as he is, he'll shrink astonished from me; But if he be the favourite of the fair, loved by the first of Caledonia's dames, He'll turn upon me, as the lion turns Upon the hunter's spear. Ran. 'Tis shrewdly thought. 
Glen. When we grow loud, draw near. But let my lord

His rising wrath restrain.

[E.vit Lori) Randolph.

'Tis strange, by heaven!

That she should run full tilt her fond career

To one so little known. She, too, that seemed

Pure as the winter stream, when ice, embossed,

Whitens its course. Even I did think her chaste,

Whose charity exceeds not. Precious sex,

Whose deeds lascivious pass Glenalvon's thoughts!

\section{Enter Norval.}

His port I love: he's in a proper mood

To chide the thunder, if at him it roared. [Aside.

Has Norval seen the troops?

Norv. The setting sun

With yellow radiance lightened all the vale,

And as the warriors moved, each polished helm, Corslet, or spear, glanced back his gilded beams. The hill they climbed, and, halting at its top, Of more than mortal size, towering, they seemed An host angelic, clad in burning arms.

Glen. Thou talk'st it well; no leader of our host In sounds more lofty speaks of glorious war.

Nori'. If I shall e'er acquire a leader's name, $\mathrm{My}$ speech will be less ardent. Novelty

Now prompts my tongue, and youthful admiration

Vents itself freely; since no part is mine

Of praise pertaining to the great in arms. 
Glen. You wrong yourself, brave sir; your martial deeds

Have ranked you with the great. But mark me, Norval ;

Lord Randolph's favour now exalts your youth, Above his veterans of famous service;

Let me, who know these soldiers, counsel you. Give them all honour: seem not to command; Else they will scarcely brook your late-sprung power, Which nor alliance props, nor birth adorns.

Norv. Sir, I have been accustomed all my days To hear and speak the plain and simple truth; And though I have been told that there are men Who borrow friendship's tongue to speak their scorn, Yet in such language I am little skilled: Therefore I thank Glenalion for his counsel, Although it sounded harshly. Why remind Me of my birth obscure? Why slur my power With such contemptuous terms?

Glen. I did not mean

To gall your pride, which now I sec is great. Norv. My pride!

Glen. Suppress it, as you wish to prosper. Your pride's excessive. Yet, for Randolph's sake, I will not leave you to its rash direction. If thus you swell, and frown at high-born men, Think you, will they endure a shepherd's scorn?

Norv. A, shepherd's scorn!

Glen. Y'es; if you presume

To bend on soldiers these disdainful eyes, As if you took the measure of their minds, 
And said in secret, You're no match for me, What will become of you?

Norv. If this were told! - $\quad$ [Aside.

Hast thou no fears for thy presumptuous self?

Glen. Ha! dost thou threaten me?

Norv. I)idst thou not hear?

Glen. Unwillingly I did; a nobler foe

Had not been questioned thus; but such as theeNorv. Whom dost thou think me?

Glen. Norval.

Noro. So I am

And who is Norval in Glenalvon's eyes?

Glen. A peasant's son, a wandering beggar boy; At best no more; even if he speaks the truth.

Nor:. False as thou art, dost thou suspect my truth?

Glen. Thy truth: thou'rt all a lie; and false as hell

Is the vain-glorious tale thou told'st to Randolph.

Norv. If I were chained, unarmed, and bed-rid old, Perhaps I should revile; but as I an,

I have no tongue to rail. The humble Norval

Is of a race who strive not but with deeds.

Did I not fear to freeze thy shallow valour,

And make thee sink too soon beneath my sword,

I'd tell thee-what thou art. I know thee well.

Glen. Dost thou not know Glenalvon, born to command

Ten thousand slaves like thee-

Nori'. Villain, no more!

[Drare's.

Draw and defend thy life. I did design

To have defied thee in another cause; 
But Heaven accelerates its vengeance on thee. Now for my own and Lady Randolph's wrongs.

\section{Enter LORD RaNinolph.}

Ran. Hold, I command you both. The man that stirs

Makes me his foe.

Norz. Another voice than thine,

That threat had vainly sounded, noble Randolph.

Glen. Hear him, my lord; he's wondrous condescending :

Mark the humility of shepherd Norval!

Norv. Now you may scoff in safety.

Ran. Speak not thus,

[Sheathes his sword.

Taunting each other; but unfold to me

The cause of quarrel: then I judge betwixt you.

Nori: Nay, my good lord, though I revere you much,

My cause I plead not, nor demand your judgment.

I blush to speak-I will not, cannot speak

'Th' opprobrious words that I from him have borne.

To the liege lord of my dear native land

I owe a subject's homage; but even him

And his high arbitration I'd reject.

Within my bosom reigns another lord-

Honour, sole judge, and umpire of itself.

If my free speech offend you, noble Randolph,

Revoke your favours, and let Norval go

Hence as he came, alone, lut not dishonoured.

Ran. Thus far I'll mediate with impartial voice: 
The ancient foc of Caledonia's land

Now waves his banners o'er her frighted fields;

Suspend your purpose till jour country's arms

Repel the bold invader; then decide

The private quarrel.

Glen. I agree to this.

Nori. And I.

Enter Sirvant.

Serv. The banquet waits.

Ran. We come.

[Exit reith Servant.

Glen. Norval,

I et not our variance mar the social hour, Nor wrong the hospitality of Randolph.

Nor frowning anger, nor yet wrinkled hate, Shall stain my countenance. Smooth thou thy brow; Nor let our strife disturb the gentle dame.

Norv. Think not so lightly, sir, of my resentment; When we contend again, our strife is mortal.

[Exeunt. 


\section{JEAN ELLIOT.}

$1727-1 \mathrm{SO}_{5}$.

One of the old Scots ladies of good family, whose presence was a typical feature of society in Edinburgh during the last twenty years of the eighteenth century, was Niss Jean Elliot. Her residence was in Brown square, then the fashionable quarter. There she kept up some state, being remarked, among wreater things, for the fact that she kept her own sedan-chair. She was the only lady in Edinburgh who did so. Riddels Carr, in his Border Ilemories, describes her, perhaps at a somewhat earlier date, as possessing "a sensil)le face, and a slender, well. shaped figure. In manner grave, and reservel to strangers, she had high aristocratic notions which she took no pains to conceal." The high breeding on which she prided herself was not, however, all in name. On at least one occasion she had proved herself a woman of character and courage. During the Relellion of 1745 her father was one of the law officers of the Crown, and when the Jacobite army came to Edinburgh a detachment was sent to seize him. In this crisis it is recorded that she "received and entertained the officers, and lyy her presence of mind and composure averted the danger."

Third daughter of Sir (iilbert Elliot, second laronet of Mintu and one of the Lords of Session, the authoress of "The liowers 0 ' the Forest" came of a pretic family, for her father and her brother both wrote verse. The circumstances of the composition of her famous and only song are well known. One evening, alout the year 1756 , she was riding home after nightfall in a carriage with her lorother Gilbert to Minto llouse. It dinner some mention had been made of Flodken, and someonc had "fuoted the refrain of an old, forgotten lament on the sulject, "The Flowers o' the Forest are a' wede awa'." This, her brother suggested, would make a suitalble subject for a sing. And there, leaning back in the carriage as it rolled along the dark roads, she composed her hallad. The immerliate subject of the piece, of course, is the fall of the "Seventy of Selkirk" with James IV. on Flodden Field. The first and last lines, as well as the beautiful, pathetic air to which it is sung, are ancient. The rest is Miss Jean Elllot's composition. When it tirnt 
appeared, the entire composition was supposed to be antique, and some confusion was introduced into the question by Ilerd, who included Miss Elliot's, along with Mrs. Cocklourn's stanzas with the same title, in a long, single lallacl. This, however, is of obvionsly modern make-up.

Miss Jean Elliot was horn at Minto IIouse, in Teviotdale, and died at Mount Teviot, Roxburghshire, then the residence of her brother, Aclmiral Eilliot.

\section{THE FLOWERS O' THE FOREST.}

I've: heard them lilting at the ewe-milking,

Lasses a-tilting before the dawn of day;

But now there is moaning in ilka green loaning $\mathrm{r}$; 'lane.

The flowers o' the forest are a' wede away ${ }^{2}$. = weeded away.

At buchts 3 in the morning nae blythe lads are 3 sheepfolds. scorning 4 ;

4 rallying.

Lasses are lanely and dowie and wae;

Nae daffin', nae gabbin's, but sighing and sabbing $;^{5}$ No joking, no $_{\text {chatting. }}$ Ilk ane lifts her leglin ${ }^{6}$ and hies her away. ${ }^{6}$ milk-pail.

In hairst 7 at the shearing ${ }^{8}$ nae youths now are jeering $;{ }_{8}^{7}$ harvest.

Bandsters 9 are runkled and lyart ${ }^{\text {to }}$ and grey; $; \begin{gathered}9 \text { Shear-binders. } \\ 1 \text {, wrinkled and }\end{gathered}$

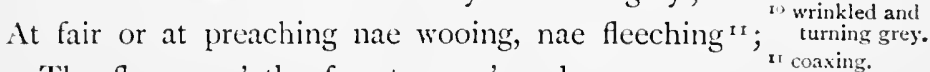
'The flowers o' the forest are a' wede away.

At e'en in the gloaming nae younkers are roaming 'Bout stacks wi' the lasses at bogle to play;

But ilk maid sits dreary, lamenting her dearie'The flowers o' the forest are a' wede away. 
Dule and wae for the order sent our lads to the Border !

The English for ance by guile wan the day; 'The flowers o' the forest, that fought aye the foremost, The prime of our land, are cauld in the clay.

We'll hear nae mair lilting at the ewe-milking,

Women and bairns are heartless and wae; Sighing and moaning in ilka green loaning'The flowers o' the forest are a' wede away. 


\section{JOHN LAPRAIK.}

$1727^{-1} 807$.

When Johnson was publishing his Scots Musical Musezum, one of the songs sent to him by Burns was "When I upon thy loosom lean." The poet had heard it sung at a country " rockin'," and he was so struck with its merits that he forthwith opened a poetic correspondence with its author. To this correspondence, and to the one fine song, is owed the memory of John I apraik.

An account of Lapraik's life is given in Ayrshire Contempo. raries of kurns. For several generations his forlears had owned the lands of Dalfram, in the neighbourhood of Muirkirk, and for the first forty years of his life Lapraik himself enjoyed their possession. The failure, however, of "that villanous bulble, the Ayr Bank," involved him, with many others of the landholders of Ayrshire, in ruin. In turn he tried milling and farming, without success; and in his last days he supported himself and his family by keeping a small publicbouse and the village post office in Muirkirk. In 1785, when Burns knew him, he had sold his estate, and was the miller at Muirsmill; and no doubt fully deserved the description of "bauld Lapraik, the king o' hearts," bestowed on him by his illustrious contemporary.

It was while imprisoned for debt in Ayr gaol, a few years

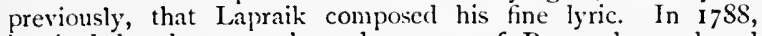
inspired by the example and success of Burns, he gathered together and published, at Kilmarnock, a collection of his pieces, including this song among others. In the volume it wears an English dress, and moves somewhat more stiffly than the Museum version, but whether the finer touches of the latter are due to Burns, or to Lapraik himself, or to the improvements of oral transmission, it is impossible to say. As it stands in the Wuseum it remains one of the few finest lyrics of wedcled happiness in the language. 


\section{IVHEN I UPON THY BOSOM LEAN.}

WheN I upon thy bosom lean,

And fondly clasp thee a' my ain,

I glory in the sacred ties

That made us ane, wha ance were twain.

A mutual flame inspires us baith-

The tender look, the melting kiss;

Even years shall ne'er destroy our love,

But only gi'e us change o' bliss.

Ha'e I a wish? it's a' for thee,

I ken thy wish is me to please;

Our moments pass sae smooth away

That numbers on us look and gaze.

Weel pleased, they see our happy days,

Nor envy's sel' finds aught to blame;

And aye when weary cares arise,

Thy bosom still shall be my hame.

I'll lay me there and tak' my rest;

And if that aught disturb my dear,

I'll bid her laugh her cares away,

And bey her not to drap a tear.

Ha'e I a joy? its a' her ain.

United still her heart and mine;

They're like the woodbine round the tree,

'That's twined till death shall them disjoin. 


\title{
WILLIAM FAI.CONER.
}

\author{
I $730-1769$.
}

The first and greatest of British marine poets was the son of an Edinburgh barber (he was born in the Nethcrbow), and his life presents a scries of slow triumphs over adverse fortune alternating with reverses ruinous and disheartening. His expcrience, in fact, was again and again that of the vessel he has described in his finest pocm-a voyage slowly advancing to a certain point of prosperity, and then suddenly dissolving in wreck and disaster.

It was against Falconer's own desire that, as a lad, he entered upon the sailor's life. He made his way in it, however, to the position of second mate, and would shortly have earned further promotion, when the vessel on which he sailed, the "Britannia," merchantman, trading letween Alexandria and Venice, was wrecked off Cape Colonna. Of all on board, he and other two alone escaped with their lives. This occurrence, which happened about the year 1749 , furnished the material for his poem.

"The Shipwreck" was published in 1762 , and at once brought its author into note, not only receiving great praise from the critics, but becoming immediately popular. The Duke of York, to whom it was dedicated, took an interest in the poet, and procured him a rating as midshipman on board the "Royal George," flag-ship of Sir Edward Hawke. When, a little later, the "Royal George" went out of commission, Falconer received the appointment of purser of the "Glory" frigate. This vessel was then lying up at Shcerness, but the captain's cabin was fitted up for him, and there he lived and wrought, producing a "Universal Dictionary of the Marine," which was for long quoted as an authority: Relying on his prospects of employment, he also married. His bride was Miss Iicks, the beautiful daughter of the surgeon of Sheerness Yard; and it is recorded that she made him an excellent wife.

Presently, however, his good fortune failed him; he was in London, reduced to live in an obscure garret. His last glimpse of prosperity came in 1769 . The "Aurora" frigate was going to India with a special Commission, and Falconer was appointed purser to the vessel, with a prospect of becoming secretary to the Commissioners. Full of hope in the future which seemed to be opening before him, he sailed from England. The "Aurora" reached the Cape in safety, and proceeded upon the final stage of her voyage. But she never reached her destination. From the hour when she left the Cape to the present day nothing has ever 
been heard either of the vessel or of those on board. So, appropriately, if pathetically enough, the sailor-poet, whose chief work was of shipwreck, perished himself upon the sea.

Besides "The Shipwreck," Falconer wrote several other shorter poems, including a political satire, "The Demagogue," directed against Pitt, none of which is now perhaps of much account. "The Shipwreck" itself, to which the poet made large additions in 1764 , remains a somewhat unequal performance in three cantos. Much of it follows the conventional strain of the school of Pope, and it is only where the author writes directly out of his own knowledge and experience that the merit, the vigour, interest, and originality of his work appear. Falconer's "Shipwreck," it will be remembered, furnished Byron with material for the storm scene in "Don Juan."

The best editions of Falconer's poems are those of the Chiswick Press and the more recent Aldine Poets.

\section{THE SMILING PLAINS.}

THE smiling plains, profusely gay, Are dressed in all the pride of May;

The birds on every spray above

To rapture wake the vocal grove.

But ah! Miranda, without thee,

Nor spring nor summer smiles on me;

All lonely in the secret shade,

I mourn thy absence, charming maid!

O soft as love! as honour fair!

Serenely sweet as vernal air!

Come to my arms; for you alone

Can all my absence past atone.

O come: and to my bleeding heart

The sovereign balm of love impart:

Thy presence lasting joy shall bring

$\Lambda$ nd give the year eternal spring. 


\section{THE SHIPWRECK.}

[Canto I. describes the arrival of the ship at Candia. IIer officers are Albert the captain, Rodmond the first mate, Arion the second mate, and I'alemon the purser and son of the owner, who has been sent to sea to cure him of a passion for the daughter of Albert. Ilis love-story is recounted to Arion; a social scene in the forecastle is described, and the vessel sails. Canto II. describes with much technique the various operations of shortening sail as the storm rises, and the labour of the ship in the heavy seas. The cannon are at last thrown overboard, the mizzen-mast is cut away, and the ressel is resigned to scud under hare poles up the (iulf of Corinth.]

\section{CANTO III.}

WHEN in a barbarous age, with blood defiled,

The human savage roamed the gloomy wild,

When sullen Ignorance her flag displayed,

And rapine and revenge her voice obeyed,

Sent from the shores of light, the Muses came,

The dark and solitary race to tame.

"Twas theirs the lawless passion to control,

And melt in tender sympathy the soul,

The heart from vice and error to reclaim,

And breathe in human breasts celestial flame.

The kindling spirit caught th' empyreal ray,

And glowed congenial with the swelling lay. 
Roused from the chaos of primeval night, At once fair truth and reason sprung to light. When great Mæonides, in rapid song, The thundering tide of battle rolls along, Each ravished bosom feels the high alarms, And all the burning pulses beat to arms. From earth upborne, on Pegasean wings, Far through the boundless realms of thought he springs ;

While distant poets, trembling as they view His sunward flight, the dazzling track pursue. But when his strings, with mournful magic, tell What dire distress Laertes' son befel, The strains, meand'ring through the maze of woe, Bid sacred sympathy the heart o'erflow. Thus in old time, the Muses' heavenly breath With vital force dissolved the chains of death; Each bard in epic lays began to sing, Taught by the master of the vocal string. 'Tis mine, alas! through dangerous scenes to stray, Far from the light of his unerring ray. While, all unused the wayward path to tread, Darkling I wander with prophetic dread, To me in vain the bold Mreonian lyre Awakes the numbers, fraught with living fire. Full oft, indeed, that mournful harp of yore Wept the sad wanderer lost upon the shore; But o'er that scene th' impatient numbers ran, Subservient only to a nobler plan. 'Tis mine, the unravelled prospect to display, And chain the events in regular array; 
Though hard the task, to sing in varied strains, While all unchanged the tragic theme remains. Thrice happy! might the secret powers of art Unlock the latent windings of the heart; Might the sad numbers draw compassion's tear For kindred miseries, oft beheld too near; For kindred wretches, oft in ruin cast On Albion's strand, beneath the wintry blast; For all the pangs, the complicated woe, Her bravest sons, her faithful sailors know. So pity, gushing o'er each British brcast, Might sympathise with Britain's sons distrest. For this, my theme through mazes I pursue, Which nor Mronides nor Maro knew.

A while the mast, in ruins dragged behind, Balanced th' impression of the helm and wind. The wounded serpent agonized with pain, Thus trails his mangled volume on the plain. But now, the wreck dissevered from the rear, The long reluctant prow began to veer; And while around before the wind it falls, "Square all the yards!" th' attentive master calls.

"You timoneers, her motion still attend! For on your steerage all our lives depend. So, steady: meet her, watch the blast behind, And steer her right before the seas and wind!" "Starboard, again!" the watchful pilot cries; "Starboard!" th' obedient timoneer replies; Then to the left the ruling helm returns; The wheel revolves; the ringing axle burns; 'The ship, no longer foundering by the lee, 
Bears on her side th' invasions of the sea. All lonely o'er the desert waste she flies, Scourged on by surges, storm, and bursting skies. As when the masters of the lance assail, In hyperborean seas, the slumbering whale; Soon as the javelins pierce his scaly hide, With anguish stung, he cleaves the downward tide. In vain he flies; no friendly respite found, His life-blood gushes through th' enflaming wound. The wounded bark, thus smarting with her pain, Scuds from pursuing waves across the main; While, dashed apart by her dividing prow, Like burning adamant the waters glow. Her joints forget their firm elastic tone, Her long keel trembles, and her timbers groan. Upheaved behind her, in tremendous height, The billows frown, with fearful radiance bright. Now shivering, o'er the topmast wave she rides, While, deep beneath, th' enormous gulf divides. Now, launching headlong down the horrid vale, She hears no more the roaring of the gale; Till up the dreadful height again she flies, Trembling beneath the current of the skies. As that rebellious angel who, from Heaven, To regions of eternal pain was driven; When dreadless he forsook the Stygian shore, The distant realms of Eden to explore; Here, on sulphureous clouds sublime upheaved, With daring wing th' infernal air he cleaved; There, in some hideous gulf descending prone, Far in the rayless void of night was thrown. 
Even so she scales the briny mountain's height, Then down the black abyss precipitates her flight. The masts, around whose tops the whirlwinds sing, With long vibration round her axle swing. To guide the wayward course amid the gloom, 'The watchful pilots different posts assume. Albert and Rodmond, stationed on the rear, With warning voice direct each timoneer: High on the prow the guard Arion keeps, To shun the cruisers wandering o'er the deeps:

Where'er he moves, Palemon still attends, As if on him his only hope depends:

While Rodmond, fearful of some neighb'ring shore, Cries, ever and anon, "Look out afore!"

Four hours thus scudding on the tide she flew, When Falconera's rocky height they view. High o'er its summit, through the gloom of night, The glimmering watch-tower casts a mournful light. In dire amazement riveted they stand, And hear the breakers lash the rugged strand. But soon beyond this shore the vessel flies, Swift as the rapid eagle cleaves the skies. So, from the fangs of her insatiate foe, O'er the broad champaign scuds the trembling roe. That danger past, reflects a feeble joy; But soon returning fears their hope destroy. Thus, in th' Atlantic, oft the sailor eyes, While melting in the reign of softer skies, Some alp of ice, from polar regions blown, Hail the glad influence of a warmer zone. Its frozen cliffs attempered gales supply; 
In cooling stream th' aërial billows fly; Awhile delivered from the scorching heat, In gentler tides the feverish pulses beat.

So, when their trembling vessel passed this isle, Such visionary joys the crew beguile; Th' illusive meteors of a lifeless fire, Too soon they kindle, and too soon expire.

[The action of the poem is here suspended in order to describe the classic associations of the region in which the poet finds himself. The narrative is resumed as the vessel drives past the cliffs of St. George towards the headland of Colonna.]

But now Athenian mountains they descry, And o'er the surge Colonna frowns on high. Beside the cape's projecting verge are placed A range of columns, long by time defaced, First planted by devotion to sustain, In elder times, Tritonia's sacred fane.

Foams the wild beach below, with madd'ning rage, Where waves and rocks a dreadful combat wage. The sickly heaven, fermenting with its freight, Still vomits o'er the main the feverish weight. And now, while winged with ruin from on high, Through the rent cloud the ragged lightnings fly, A flash, quick-glancing on the nerves of light, Struck the pale helmsman with eternal night. Rodmond, who heard a piteous groan behind, Touched with compassion, gazed upon the blind; And, while around his sad companions crowd, He guides th' unhappy victim to the shroud. "Hie thee aloft, my gallant friend!" he cries; "'Thy only succour on the mast relies." 
The helm, bereft of half its vital force,

Now scarce subdued the wild unbridled course.

Quick to th' abandoned wheel Arion came,

'The ship's tempestuous sallies to reclaim.

Amazed he saw her, o'er the sounding foam

Upborne, to right and left distracted roam.

So gazed young lhaëton, with pale dismay,

When, mounted in the flaming car of day,

With rash and impious hand, the stripling tried

'Th' immortal courses of the sun to guide.

The vessel, while the dread event draws nigh,

Seems more impatient o'er the waves to fly.

Fate spurs her on. Thus, issuing from afar,

Advances to the sun some blazing star;

And, as it feels th' attraction's kindling force,

Springs onward with accelerated course.

With mournful look the seamen eyed the strand,

Where death's inexorable jaws expand.

Swift from their minds elapsed all dangers past, As, dumb with terror, they beheld the last.

Now, on the trembling shrouds, before, behind,

In mute suspense they mount into the wind.

The genius of the deep on rapid wing

The black eventful moment seemed to bring;

The fatal sisters on the surge before,

Yoked their infernal horses to the prore.

'The steersmen now received their last command,

To wheel the ressel sidelong to the strand.

Twelve sailors, on the foremast who depend,

High on the platform of the top ascend.

Fatal retreat! for while the plunging prow 
Immerges headlong in the wave below, Down-prest by watery weight the bowsprit bends, And from above the stem deep-crashing rends. Beneath her beak the floating ruins lie; The foremast totters, unsustained on high ; And now the ship, fore-lifted by the sea, Hurls the tall fabric backward o'er the lee; While, in the general wreck, the faithful stay Drags the main-topmast from its post away. Flung from the mast, the seamen strive in vain Through hostile floods their vessel to regain. The waves they buffet till, bereft of strength, O'erpowered they yield to cruel fate at length. 'The hostile waters close around their head, They sink for ever, numbered with the dead. Those who remain their fearful doom await, Nor longer mourn their lost companions' fate. The heart that bleeds with sorrows all its own, Forgets the pangs of friendship to bemoan. Albert and Rodmond and Palemon here, With young Arion, on the mast appear. Even they, amid the unspeakable distress, In every look distracting thoughts confess; In every vein the refluent blood congeals; And every bosom fatal terror feels.

Inclosed with all the demons of the main, They viewed th' adjacent shore, but viewed in vain. Such torments in the dread abodes of hell, Where sad despair laments with rueful yellSuch torments agonize the damned breast, While fancy views the mansion of the blest. 
l'or Heaven's sweet holp their suppliant cries implore;

But Heaven relentless deigns to help no more.

And now, lashed on by destiny severe,

With horror fraught, the dreadful scene drew near.

The ship hangs hovering on the verge of death, Hell yawns, rocks rise, and breakers roar beneath.

In vain, alas! the sacred shades of yore

IVould arm the mind with philosophie lore;

In vain they'd teach us, at the latest breath, 'To smile serene amid the pangs of death.

Even Zeno's self, and Epictetus old, This fell abyss had shuddered to behold. Had Socrates, for godlike virtue famed, And wisest of the sons of men proclaimed, Beheld this scene of frenzy and distress, His soul had trembled to its last recess. O yet confirm my heart, ye powers above, 'This last tremendous shock of fate to prove!

The tottering frame of reason yet sustain;

Nor let this total ruin whirl my brain!

In vain the cords and axes were prepared, For now the audacious seas insult the yard; High o'er the ship they throw a horrid shade, And o'er her burst in terrible cascade. Uplifted on the surge, to heaven she flies, Her shattered top half buried in the skies, 'Then, headlong plunging, thunders on the ground, Earth groans, air trembles, and the deeps resound. Her giant bulk the dread concussion feels, And quivering with the wound, in torment reels. So reels, convulsed with agonizing throes, 
The bleeding bull beneath the murd'rer's blows.

Again she plunges! hark! a second shock Tears her strong bottom on the marble rock. Down on the vale of death, with dismal cries, The fated victims shuddering roll their eyes In wild despair; while yet another stroke With deep convulsion rends the solid oak; Till like the mine, in whose infernal cell The lurking demons of destruction dwell, At length asunder torn, her frame divides, And crashing spreads in ruin o'er the tides.

$\mathrm{O}$ were it mine with tuneful Maro's art To wake to sympathy the feeling heart, like him the smooth and mournful verse to dress In all the pomp of exquisite distress;

Then too severely taught by cruel fate, To share in all the perils I relateThen might I, with unrivalled strains, deplore 'Th' impervious horrors of a leeward shore.

As o'er the surge the stooping main-mast hung, Still on the rigging thirty seamen clung. Some, struggling, on a broken crag were cast, And there by oozy tangles grappled fast, Awhile they bore th' o'erwhelming billows rage, Unequal combat with their fate to wage; Till all benumbed and feeble they forego Their slippery hold, and sink to shades below. Some, from the main-yard-arm impetuous thrown On marble ridges die without a groan. Three, with Palemon, on their skill depend, And from the wreck on oars and rafts descend. 
Now on the mountain-wave on high they ride, 'Then downward plunge beneath th' involving tide;

'Till one, who seems in agony to strive,

The whirling breakers heave on shore alive:

The rest a speedier end of anguish knew, And pressed the stony beach a lifeless crew. Next, O unhappy chief! th' eternal doom Of Heaven decreed thee to the briny toml). What scenes of misery torment thy view ! What painful struggles of thy dying crew: Thy perished hopes all buried in the flood, O'erspread with corses! red with human blood! So, pierced with anguish, hoary Priam gazed, When 'Troy's impcrial dome in ruin blazed; While he, severest sorrow doomed to feel, Expired beneath the victor's murdering steel. Thus with his helpless partners to the last, Sad refuge! Albert hugs the floating mast. His soul could yet sustain this mortal blow, But droops, alas, beneath superior woe; For now soft nature's sympathetic chain Tugs at his yearning heart with powerful strain. His faithful wife for ever doomed to mourn For him, alas! who never shall return; To black adversity's approach exposed, With want and hardships unforeseen enclosed; His lovely daughter left without a friend, Her innocence to succour and defend; By youth and indigence set forth a prey To lawless guilt, that flatters to betray. While these reflections rack his feeling mind, 
Rodmond, who hung beside, his grasp resigned; And, as the tumbling waters o'er him rolled, His outstretched arms the master's legs infold. Sad Albert feels the dissolution near, And strives in vain his fettered limbs to clear; For death bids every clinching joint adhere. All faint, to Heaven he throws his dying eyes, And, "O protect my wife and child," he cries. The gushing streams roll back th' unfinished sound; He grasps, he dies, and tumbles to the ground.

Five only left of all the perished throng, Yet ride the pine which shoreward drives along; With these Arion still his hold secures, And all th' assaults of hostile waves endures. O'er the dire prospect as for life he strives, He looks if poor Palemon yet survives. "Ah, wherefore, trusting to unequal art, Didst thou, incautious, from the wreck depart? Alas! these rocks all human skill defy, Who strikes them once beyond relief must die; And now sore wounded thou perhaps art tost On these, or in some oozy cavern lost." Thus thought Arion, anxious gazing round: In vain, his eyes no more Palemon found. The demons of destruction hover nigh, And thick their mortal shafts commissioned fly; And now a breaking surge, with forceful sway, Two next Arion furious tears away. Hurled on the crags, behold, they grasp, they bleed, And groaning, cling upon th' illusive weed : Another billow bursts in boundless roarArion sinks, and memory views no more. 
$\Lambda \mathrm{h}$, total night and horror here preside.

My stunned ear tingles to the whizzing tide.

It is the funeral knell; and gliding near,

Methinks the phantoms of the dead appear.

But lo! emerging from the watery grave,

Again they float incumbent on the wave!

Again the dismal prospect opens round,

The wreck, the shores, the dying and the drowned.

And see, enfeebled by repeated shocks,

Those two who scramble on th' adjacent rocks,

Their faithless hold no longer can retain,

They sink o'erwhelmed, and never rise again.

Two, with Arion, yet the mast upbore,

That now above the ridges reached the shore.

Still trembling to descend, they downward gaze

With horror pale, and torpid with amaze.

The floods recoil, the ground appears below,

And life's faint embers now rekindling glow.

Awhile they wait th' exhausted waves retreat,

Then climb slow up the beach with hands and feet.

O Heaven, delivered by whose sovereign hand,

Still on the brink of hell they shuddering stand,

Receive the languid incense they bestow,

That, damp with death, appears not yet to glow.

To Thee each soul the warm oblation pays,

With trembling ardour of unequal praise.

In every heart dismay with wonder strives,

And hope the sickened spark of life revives.

Her magic powers their exiled health restore,

Till horror and despair are felt no more. 


\section{WILLIAM JULIUS MICKLE.}

\section{734-1 788 .}

It is well for this victim of a piece of careless editing that his fame does not all depend upon one poetic performance. The writer of the disputed song of "The Sailor's Wife," better known as "There's nae luck about the house," was also the author, among other pieces, of the ballad of "Cumnor Hall," which afforded the suggestion for Scott's "Kenilworth," and was the translator of the great Portuguese epic, Camoens' "Lusiad."

Born at Langholm, where his father was minister, Mickle began life as a brewer. He was, however, unfortunate in business, and to escape his creditors betook himself to London. There for a time he subsisted chiefly on the patronage of Lord Lyttleton; but presently he became corrector for the Clarendon Press, and acquitted himself in various fields as a man of letters and a poet. It stands to his credit that, whenever he found himself in the possession of means, he honourably paid all his former debts. A little later, determining to make a bid for fortune in a bolder way, he obtained the post of secretary to the commander of a naval expedition sailing for the coast of Portugal. The fame of his translation of the national poem had preceded him, and he was received with much honour at Lisbon. The fortune of war in a single year made him a man of substance. Enriched with prize-money, he returned home to marry and settle in the enjoyment of domestic life in the neighbourhood of Oxford.

Mickle's various poems possess no inconsiderable merit, his feeling for scenery in particular having been remarked as true, tender, and full. But the gem of them all, if, as there is every reason to believe, it is his, remains "The Sailor's Wife." Burns gave it as his opinion that this song was "one of the most beautiful in the Scots or any other language." The piece began to be hawked about the streets in loroadsheets about the year 1771 or 1772 , and it was printed in Ilerd's collection in 1776 . No one doubted Mickle's authorship of it till the year 1810, when the careless Cromek, in his Ricliques of Robert Burns, gave it out as the work of one Jean Adlams, who had leen a schoolmistress in Cartsdyke, Greenock. Cromek's anthority was Mrs. Fullarton, a pupil of Jean Adams, who, with others, stated that 
she had heard the schoolmistress recite the song as her own composition. Presently, however, Cromek changed his opinion on learning from the Rev. John Sim, Mickle's biographer, that a copy of "There's nae luck," in Mlickle's handwriting, learing marks of correction as a first copy, had been found among the poet's papers after his death, and that Mrs. Mickle distinctly remembered her husband giving her the song as his own composition, and explaining to her, as she was an Englislıwoman, the Scots words which it contained. The point, nevertheless, has been debated many times since. In particular it has been pointed out that none of Mickle's other poems is in the Scots dialect, that he was unfamiliar with the life of a port, and that the song contains many tonches which are peculiarly feminine. It is also noted that "The Sailor's Wife" does not appear in any edition of Mickle's poems printed during his lifetime. But it was not printed, either, in Jean Adams' volume, which she published in 1734. Mickle, moreover, as we have scen, led the life of a sailor for over a year; and he was familiar enough, as a native of the Border, with the Scottish dialect. As for the feminine touches, they would only have been set down as high points to the credit of the poet's imagination had not Cromek's suggestion given them another bearing. And the outrageous way in which Cromek allowed himself, in his "Kemains of Nithsdale and Galloway Song," to be deceived by Allan Cunningham and others, is enough for ever to discredit his literary acumen. The point between Mickle and Jean Adams has been successively discussed by Stenhouse in his "Illustrations of the Lyric Poetry and Music of Scotland" (1820), in Ross's "Book of Scottish Poems" (1884), by a writer in the Athencum of Jan. 27, 1877, and by Mr. Cuthbert Iladden in the Scottish Keview for April, 1895. All these writers sum up in favour of Mickle. The opinion of Dr. Whitelaw, editor of Blackie's " Book of Scottish Songs," is that Jean Adams may have written a song with some such burden as the one in question, and that this was improved on by Mickle to such an extent as to make it his own.

Jean Adams appears to have been a woman of enthusiasm and energy. But she was unfortunate in life, and died in the town's hospital of Glasgow in 1765. Mickle's poetical works were edited with a "life" by the Rev. J. Sim in I806. In the song as frequently printed, a penultimate stanza beginning "The cauld blasts" is said to have been interpolated by Dr. Beattie. 


\section{THE SAILOR'S WIFE.}

AND are ye sure the news is true?

And are ye sure he's weel?

Is this a time to talk o' wark?

Ye jades, lay by your wheel!

Is this a time to talk o' wark,

When Colin's at the door?

(ii'e me my cloak-I'll to the quay,

And see him come ashore.

For there's nae luck about the house,

'There's nae luck ava',

'There's little pleasure in the house,

When our gudeman's awa'.

Rise up and mak' a clean fireside,

Put on the meikle pat:

Gi'e little Kate her cotton gown,

And Jock his Sunday's coat. 
And mak' their shoon as black as slaes,

Their hose as white as snaw;

It's a' to please my ain gudeman,

He likes to see them braw.

There is twa hens upon the bauk',

' upper rafter.

' $\mathrm{S}$ been fed this month and mair;

Mak' haste and thraw their necks about,

That Colin weel may fare!

And spread the table neat and clean,

Gar ilka thing look braw;

It's a' for love of my gudeman,

For he's been lang awa'.

O gi'e me down my bigonets ${ }^{2}$,

My bishop-satin gown;

For I maun tell the baillie's wife

That Colin's come to town.

My Sunday shoon they maun gae on,

My hose o' pearl blue;

It's a' to please my ain gudeman,

For he's baith leal and true.

Sae true's his word, sae smooth's his speech,

His breath like caller air;

His very fit has music in't

When he comes up the stair.

And will I see his face again!

And will I hear him speak!

I'm downright dizzy wi' the thought,

In troth, I'm like to greet 3 ! 
Since Colin's weel, I'm weel content, I ha'e nae mair to crave; Could I but live to mak' him blest, I'm blest abune the lave. And will I see his face again! And will I hear him speak! I'm downright dizzy wi' the thought, In troth I'm like to greet ! 


\section{CUMINOR HALL.}

THE dews of summer night did fall;

The moon, sweet regent of the sky, Silvered the walls of Cumnor Hall, And many an oak that grew thereby.

Now nought was heard beneath the skies-

The sounds of busy life were stillSave an unhappy lady's sighs,

That issued from that lonely pile.

"Leicester," she cried, "is this thy love That thou so oft has sworn to me, To leave me in this lonely grove, Immured in shameful privity?

"No more thou com'st with lover's speed, Thy once-beloved bride to see; But be she alive, or be she dead, I fear, stern earl, 's the same to thee. 
"Not so the usage I received

When happy in my father's hall:

No faithless husband then me grieved;

No chilling fears did me appall.

"I rose up with the cheerful morn,

No lark more blithe, no flower more gay;

And, like the bird that haunts the thorn,

So merrily sang the livelong day.

"If that my beauty is but small, Among court ladies all despised;

Why didst thou rend it from that hall,

Where, scornful earl, it well was prized?

"And when you to me first made suit, How fair I was you oft would say! And proud of conquest, plucked the fruit, Then left the blossom to decay.

"Yes, now neglected and despised, The rose is pale, the lily's dead;

But he that once their charms so prized Is, sure, the cause those charms are dead.

"For know, when sick'ning grief doth prey, And tender love's repaid with scorn, The sweetest beauty will decay:

What floweret can endure the storm? 
" $A$ t court, I'm told, is beauty's throne, Where every lady's passing rare;

That eastern flowers that shame the sun Are not so glowing, not so fair.

"Then, earl, why didst thou leave the bed Where roses and where lilies vie, To seek a primrose, whose pale shade

Must sicken when those gauds are by?

"'Mong rural beauties I was oneAmong the fields wild flowers are fair; Some country swain might me have won, And thought my beauty passing rare.

"But, Leicester, or I much am wrong, Or 'tis not beauty lures thy vows; Rather ambition's gilded crown Makes thee forget thy humble spouse.

"Then, Leicester, why, again I pleadThe injured surely may repineWhy didst thou wed a country maid, When some fair princess might be thine?

"Why didst thou praise my humble charms, And oh! then leave them to decay? Why didst thou win me to thy arms, Then leave to mourn the livelong day? 
"The village maidens of the plain Salute me lowly as they go; Envious they mark my silken train, Nor think a countess can have woe.

"The simple nymphs, they little know How far more happy's their estateTo smile for joy-than sigh for woeTo be content-than to be great.

"How far less blest am I than themDaily to pine and waste with care! Like the poor plant that from its stem Divided, feels the chilling air.

"Nor, cruel earl, can I enjoy The humble charms of solitude! Your minions proud my peace destroy By sullen frowns or pratings rude.

"Last night, as sad I chanced to stray, The village death-bell smote my car: They winked aside, and seemed to say 'Countess, prepare, thy end is near!'

"And now, while happy peasants sleep, Here I sit lonely and forlorn; No one to sooth me as I weep, Save Philomel on yonder thorn. 
"My spirits flag, my hopes decay, Still that dread death-bell smites my ear;

And many a boding seems to say

'Countess, prepare, thy end is near!'"

Thus sore and sad that lady grieved

In Cumnor Hall, so lone and drear;

And many a heartfelt sigh she heaved, And let fall many a bitter tear.

And ere the dawn of day appeared,

In Cumnor Hall, so lone and drear, Full many a piercing scream was heard, And many a cry of mortal fear.

The death-bell thrice was heard to ring,

An ærial voice was heard to call, And thrice the raven flapped its wing Around the towers of Cumnor Hall.

The mastiff howled at village door,

The oaks were shattered on the green, Woe was the hour, for nevermore

That hapless countess e'er was seen.

And in that manor now no more

Is cheerful feast and sprightly ball :

Fo ever since that dreary hour

Have spirits haunted Cumnor Hall. 
The village maids, with fearful glance, Avoid the ancient, moss-grown wall; Nor ever lead the merry dance Among the groves of Cumnor Hall.

Full many a traveller oft hath sighed, And pensive wept the countess' fall, As, wandering onwards, they've espied The haunted towers of Cumnor Hall. 

UNIVERSITY OF CALIFORNIA LIBRARY, LOS ANGELES COLLEGE LIBRARY

This book is due on the last date stamped below. 
PR 8656 E98sc v.1 


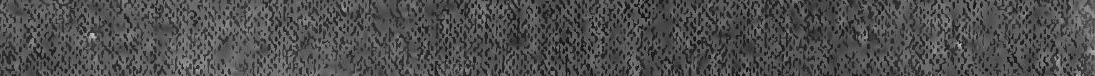

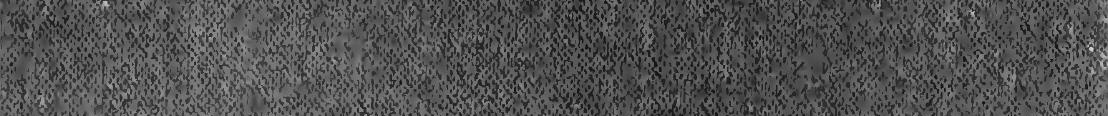
W. 